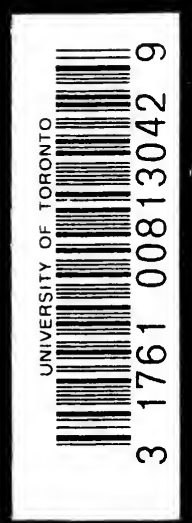








Digitized by the Internet Archive in 2007 with funding from Microsoft Corporation 

$\checkmark$ 
THE RELATION OF BRITISH POLICY TO THE DECLARATION OF THE MONROE DOCTRINE 

STODIES IN HISTORY, ECONOMIOS AND PUBLIC LAAW

EDITED BY THE FACULTY OF POLITICAL SCIENCE OF COLUMBIA UNIVERSITY

Volume CIII]

[Number 1

Whole Number 233

\section{THE RELATION OF BRITISH POLICY TO THE DECLARATION OF THE MONROE DOCTRINE}

EX

LEONARD AXEL LAWSON, Ph.D.
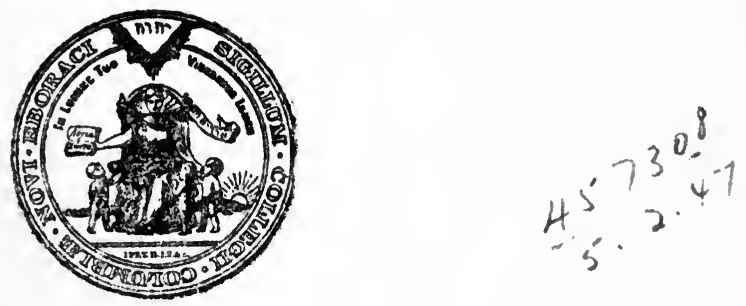

New Work

COLUMBIA UNIVERSITY

SALE AGENTS

New York: Longmans, Green \& Co.

LONDON: P.S. KING \& SON, LTD. 


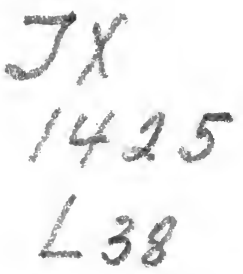

Copyright, 1922

BY

LEONARD AXEL LAWSON 


\section{PREFACE}

Ir is a matter of common knowledge that both the United States and England pursued a policy of opposition to European intervention in Latin America in 1823 . It is also well known that England's policy of opposition was based chiefly upon economic motives, and that of the United States upon political motives. But a further inquiry into the relation of British policy to that of the United States will reveal the interesting fact that upon the firmness of British opposition to intervention depended the success of the policy of the United States as formally expressed in the Monroe Doctrine. Such an inquiry is the purpose of the present treatise. The author hopes that the results of his investigations may constitute, in some degree, a contribution to the history of Anglo-American relations during the past century.

In the preparation of this treatise liberal use has been made of the sources relating to the subject. In addition to an investigation of the sources available in the United States, a search was made in the British Foreign Office Records, Public Record Office, London, which yielded an abundance of valuable information.

The author takes this occasion to acknowledge his indebtedness to the members of the Faculty of Political Science in Columbia University, under whom he pursued his graduate studies, for their guidance and inspiring interest. Especially to Professor Carlton J. H. Hayes, under whose direction this treatise was begun and completed and who has read both the manuscript and the proof, and to 
Professor R. L. Schuyler who also has read the manuscript, does he desire to recognize his debt of gratitude for their valuable criticism and many helpful suggestions. To his wife, Edith Carla Lawson, whose interest has been a constant source of inspiration, he is indebted for her help in the preparation of the manuscript in its final form.

Leonard A. Lawson.

Geneva, N. Y., MARCh, 1922. 


\section{TABLE OF CONTENTS}

PAGE

INTRODUCTION . . . . . . . . . . . . . . . 9 9

\section{CHAPTER I}

The Genesis of Anglo-American Harmony . . . . . . . . . I I

CHAPTER II

Great Britain and the Alliances. . . . . . . . . . 30

CHAPTER III

Intervention IN SPAIN .................. . 5 I

CHAPTER IV

British Interests in South America . . . . . . . . . 76 .

CHAPTER V

The Anglo-American Entente ... . . . . . . . . IO4 .

CHAPTER VI

The Monroe Doctrine . . . . . . . . . . . . . . 125

BIBLIOGRAPHY .. . . . . . . . . . . . . . . . 147

INDEX . . . . . . . . . . . . . . . . . I5I

7] 



\section{INTRODUCTION}

The Monroe Doctrine, since its proclamation in 1823 , has occupied a prominent position in the history of the foreign relations of the United States. ${ }^{1}$ Indeed, the character of these relations has often been determined largely by our interpretation of the Monroe Doctrine in its application to new problems and events as they have emerged in the course of the century. Our diplomatic negotiations with Great Britain have often related to the application of its principles. Appeals to these principles have been made whenever the commercial interests and territorial claims of England have come into conflict with the political interests of the United States in the western hemisphere.

That an American policy such as the Monroe Doctrine would ultimately operate to the disadvantage of Great Britain must have been foreseen by the British statesmen of the first quarter of the rgth century. Yet the interests of their country and its relations with the continental powers of Europe were such as to produce conditions especially favorable for its proclamation.

It is an interesting fact that the Anglo-Saxon nationsthe United States and Great Britain-both regarded the proposed intervention in Latin America as a source of danger. Both countries were opposed to it. The question

1 Beer (G. L.), The English-Speaking Peoples, (New York, 1918), p. 75; Colby (N. C.), "Present Status of the Monroe Doctrine," Anrals of the American Academy of Political and Social Science, vol. liv, p. 20; Moore (J. B.), The Principles of American Diplomacy, (New York, 1918), p. 261 . 
whether their motives for opposition were identical may conveniently be left for later consideration; but the fact remains that they manifested an interest in a joint policy in order to prevent the intervention that was threatened by the representatives of the "European System."

This Anglo-American harmony invites an inquiry into the extent to which British statesmanship contributed to the formulation and promulgation of the Monroe Doctrine in 1823. That there was such a contribution is undeniable. Whether it was merely supplementary in its influence, or a determining factor, is a question which may not be so easily answered.

Although the Monroe Doctrine, as originally proclaimed to the world, was in harmony with the geographical position, the political experiences, and the foreign policy of the United States prior to 1823 , it seems very doubtful that President Monroe would have taken the bold step of proclaiming its principles so early in our history had it not been for the knowledge of England's attitude relative to the Spanish-American question. Considering, therefore, the time when it was proclaimed, the weakness of the United States compared with an embattled alliance of Old-World powers on the one hand, and, on the other, the political and economic interests of England, her relations with the Quadruple Alliance, ${ }^{2}$ her attitude toward the Spanish-American question as expressed in her diplomatic correspondence, and her recognized naval power, it is difficult to escape the conclusion that England's contribution to the promulgation of the Monroe Doctrine was decisive in the extent of its influence.

1 The Quadruple Alliance is frequently, but incorrectly, referred to as the "Holy Alliance." After the admission of France in 1818 the term "Quintuple Alliance" is sometimes used. In this treatise the term "Quadruple Alliance" is used in its original meaning. (See pp. 32-35. 


\section{CHAPTER I}

The Genesis of Anglo-American Harmony

Notwithstanding the American Revolution and the War of I8I2, the United States and England had each pursued independently of the other a course of action, maintained certain interests, and developed principles of foreign policy which invited cooperation in the presence of common danger.

The eighteenth century, which was so productive of changes in the economic and political institutions of the world, and especially western Europe, gave direction to the foreign policy of Great Britain. That is no less true of her relations with France than of her relations with the Quadruple Alliance after the Congress of Vienna. In the case of the former, England had already in the War of the Spanish Succession, and in the Treaty of Utrecht following the conclusion of the war, shown herself emphatically opposed to any attempt of France to establish French influence over Spain and the Spanish possessions beyond the seas. ${ }^{1}$ England's opposition in that instance to the designs of Louis XIV was grounded not only upon the principle of the balance of power, but also upon the commercial advantages that would be derived from the separate existence of the colonial empires of France and Spain. A union of the two colonial empires would have been extremely disastrous to the commercial interests of England.

1 Hill (D. J.), A History of European Diplomacy, (New York, 1914), vol. iii, p. $31 \%$. 
The Treaty of Utrecht, though favorable to both the principle of the balance of power and to the colonial and commercial interests of England, was not the end of AngloFrench rivalry. ${ }^{1}$ It could be little more than a truce so long as the old colonial system prevailed with its numerous restrictions imposed by one nation upon the commerce of another. ${ }^{2}$ In these artificial restrictions which weighed heavily upon the world's trade lay the germs of further conflict. When war broke out again it assumed larger proportions, embracing within its scope not only America but India. By the Treaty of Paris of 1763 the might of England had won a decisive victory over France; and by the terms of that treaty England added, with insignificant exceptions, the French colonies to her own possessions. From this addition of territory England derived great commercial advantages, ${ }^{3}$ which, coupled with the Industrial Revolution, made England the greatest commercial power in Europe. ${ }^{4}$ It was natural that in the wars of France and England in America each should have the cooperation of its own colonists. There can be no doubt that the unity of purpose engendered a unity of feeling which, though strained by the Revolution, was bound to revive under the influence of changed circumstances.

Though the memory of common victory was not sufficiently strong to prevent the revolt of the American colonies against England under the pressure of serious economic grievances, the independence of the thirteen colonies, once recognized, paved the way for future cooperation of the

'Cambridge Modern History, (New York, 1902-1910), vol. vi, pp. $4 \mathrm{II}$ et seq.

2 Ibid., p. 4 I4.

- Ogg (F. A.), The Economic Development of Modern Europe, (New York, r9r7), p. 80.

Ibid. 
two English-speaking peoples, should circumstances suggest it. The fact of sovereign independence enabled the United States to shape its foreign policy in harmony with its geographic position, political experiences, and economic interests. In the character and aims of these policies are found the possibilities and the advantages of Anglo-American cooperation.

Meanwhile England was mightily affected by gigantic changes in her own economic life and by the political upheaval on the European continent. The Industrial Revolution and the French Revolution did not give a new direction to the foreign policy of England: they intensified and made more pronounced a policy which England had pursued for more than a century. It was a policy opposed to the aggrandizement of France.

The underlying motives of this policy may be found in the rapid development of English industry and commerce which resulted from the growth of empire and from the Industrial Revolution. ${ }^{1}$ In the course of the eighteenth century British exports increased from an annual value ${ }^{2}$ of $\mathfrak{f}^{1}, 5^{0}, 285^{3}$ in 1701 to $\mathfrak{f}_{12,142,000^{4}}$ in 1763 , to $\mathfrak{f 2 2}_{22,-}$ $095,000^{5}$ in 1792 , and to $f_{41,717,000^{\circ}}$ in 1801 . The growth of colonial possessions, coupled with the develop-

I Abbott (W.C.), The Expansion of Europe, (New York, 1918), vol. ii, pp. 347 et seq.

- The average annual value for the period 1698-170r.

${ }^{3}$ Marshall (J.), Digest of the Accounts diffused through 600 volumes of Journals, Reports, and Papers presented to Parliament since 1779, (London, 1833), pt. 3, pp. 7I-75.

- Levi (Leone), The History of British Commerce, (London, I880), p. 36.
Ibid., p. 64
- Ibid., p. 146. 
ment of British sea power, caused much of this trade to shift from the continent of Europe to the colonies. ${ }^{1}$

France also experienced an increase in the volume of her exports despite the disastrous consequences of her wars; but French trade was confined for the most part to the continent of Europe. This continental direction of French exports was owing to the nature of the goods exportedmostly fancy goods and luxuries; while British exports were staple goods for which the relatively backward populations of undeveloped countries afforded the greatest demand." Thus the colonial trade of England was growing relatively more important than that of Erance. It was natural that under these circumstances the foreign policy of England would be given a balance of emphasis consistent with the changing current of her economic interests.

It was also likely that these new developments would influence the international relations of England. Her diplomacy turned its attention more and more to the questions touching the fortunes of the western hemisphere, particularly where and when her interests were concerned. In the course of that deflection of her diplomacy England's relations with some of the continental countries of Europe became more delicate, in view of which the support that the United States might give would be a distinct advantage to the realization of her aims and the success of her policy. This change in England's foreign policy took the form of opposition to the policy of intervention pursued by the continental Allies, and the substitution for it of an understanding with the United States designed to conteract the machinations of the Quadruple Alliance.

The real motives and effects of that change will be left

1 Marshall, op. cit., pp. 74-75; cf. infra, pp. 77-86.

- Day (Clive), A History of Commerce, (New York, 1917), p. 216.

3 Infra, pp. 77-86. 
for later consideration. For the present it will suffice to point out certain factors that appear to have been fundamental to a common Anglo-American policy, such as was suggested by Canning in 1823 .

In the first place, in spite of the distance which separates the United States and England, the geographical situations of these two countries relative to the European continent have something in common: but are separated from it by bodies of water. In the case of England her geographical separation from the continent had made het inhabitants a maritime people with real interest in commercial enterprise. ${ }^{1}$ The Ocean was their highway by which distant lands could be reached. In the course of their commercial pursuits territorial acquisitions were made, and England's economic interests struck deep roots also in soil that was not English. England, by reason of the world-wide reach of her commercial interests, would, more than any other nation, need to watch carefully the current of world politics. The need for such vigilance was especially great when there was danger of a conflict between two opposing political principles that would probably have the most harmful results for British commerce and trade. The geographic fact of her insular position, then, made England a maritime and commercial power, and as such the fate of the Spanish colonies in America was a matter of deep concern to her. Similarly, the geographical situation of the United States constitutes the basis upon which the structure of our foreign policy has been reared. ${ }^{2}$ Geographical separation suggested a policy of political isolation. Distance from the

Semple (E. C.), Infiuences of Geographic Environment, (New York, Igri), p. 15; Mahan (A.T.), The Influence of Sea Power upon History, (Boston, 1893), pp. 29 et seq.

- Hart (A.B.), The Monroe Doctrine: An Interpretation, (Boston, 1915), pp. 2 et seq. 
Old World invited a policy of non-interference by America in European politics. ${ }^{1}$ Though the interest which England showed in the fate of the Spanish-American colonies was principally economic, and the motives which prompted the declaration of the great national principle - the Monroe Doctrine - by the United States were chiefly political; nevertheless, they were bottomed upon the fundamental fact of the geographical situation of each of those countries.

In the second place, England as well as the United States, was an American power by virtue of her possession of Canada. Both possessed territory on the continent of North America, much of which was not settled, and abounding in natural resources. They had a common interest in the preservation of these territories against possible attacks by other powers.

Thirdly, there was the feeling of a common heritage. The people of the United States had, after all, a British back-ground, a set of experiences and traditions which determined in a large measure the course of American civilization and American policies. In spite of the Revolution, in which the colonists fought for their rights as Englishmen, the fact that the background of the social and political life of the United States was British has never been disputed. On the contrary, there is reason for thinking that the bitterness engendered by the Revolution has been very much exaggerated. In fact, the Revolution was not directed so much against the English people as against their government. ${ }^{2}$ Many Englishmen, realizing at the time that their own hope of political emancipation was akin to that of the colonists for independence, refused to fight against the revolutionists. ${ }^{8}$

'Semple, op. cit., p. 236.

'Johnson (W. F.), America's Foreign Relations, (New York, 1916), vol. i, p. 64.

- Johnson, op. cit., vol. i, pp. 58-59. 
A feeling of animosity there certainly was, ${ }^{1}$ but no greater in intensity and duration than that which any similar event may produce as a natural consequence of long-standingt grievances for which the frailty of human nature can find redress only in the clash of arms. At any rate, the feeling of animosity easily yielded to a better relationship when it became evident that the current of European politics carried in its course an element of danger common alike to the aims and interests of the two English-speaking peoples. When that danger presented itself in the form of a proposal for continental European intervention in the affairs of the western hemisphere, it was more natural for the United States and England to unite their forces against intervention than it would have been for either of them to side with the continental Allies.

But irrespective of any hatred of England that might still have lingered in the hearts of the triumphant revolutionists long after the smoke of battle had disappeared, the people of the United States were in the eighteenth and early nineteenth centuries developing a real aversion to any suggestion of an alliance with European countries. This attitude was the product partly of their experiences as colonists and nation builders, and partly of their knowledge of the devious ways of European diplomacy and politics. They looked back, too, upon a century of European history, and they found there little but the story of wars-wars bound up with and produced by dynastic ambitions and interests. It is not surprising that as a free people they would have as little as possible to do with the crowned autocrats of Europe, who showed so little concern for the rights and welfare of the common people. Above all, they

1 Channing (E.), A History of the United States, (New York, 1912-.), vol. iv, p. 124 . 
would preserve their new-found liberty, and they discerned for that purpose an invaluable asset in their geographical isolation. ${ }^{2}$

The policy of isolation, of which the Monroe Doctrine was the emphatic announcement, had its roots in the eighteenth century. It was grounded in the belief that the United States represented ideals and principles different from those of the European countries; and that national development in conformity with those ideals and principles might be checked and stultified by European entanglement. ${ }^{2}$ It seemed to the Americans of those days that not only would such entanglements involve the expenditure of resources that might better be used for their national development, but they were looked upon as a distinct danger. ${ }^{3}$ So strong was the sentiment in favor of isolation that it could be only a question of time before it should be publicly declared as the policy of this nation." The European policy of intervention only furnished a favorable occasion. ${ }^{5}$ The American fear of the possible consequences of too close relations with Europe was paralleled by European fear of republican institutions. The danger seemed to be mutual, and the Monroe Doctrine and the Doctrine of Intervention were expressive of two contradictory political systems which circumstances suddenly brought into conflict.

President Monroe but expressed officially and formally a national policy which had long been shaping in the minds of American statesmen. ${ }^{6}$ Even before he became President,

1 Semple, op. cit., pp. 236-237.

'McLaughlin (A.C.), America and Britain, (New York, 1919), p. 99.

S North American Review, vol. clxxvi, p. 186.

- Moore (J. B.), Principles of American Diplomacy, pp. 258-259.

- Ibid.

- Johnson, op. cit., vol. i, p. 329. 
Washington spoke his opinion of what should be the relations between this country and Europe. In a letter to Jefferson, I January, I788, Washington pointed out the great need of a stronger central government for the purpose of preventing the separate states from "forming .... connection with the European Powers. . . . For our situation is such, as makes it not only unnecessary, but extremely imprudent, for us to take a part in their quarrels." 1 When war broke out between France and England in I793, President Washington gave an official character to that policy by issuing the Neutrality Proclamation on 22 April of the same year. ${ }^{2}$ It signified the withdrawal of the United States from European politics; ${ }^{3}$ and it was a powerful reminder to the statesmen of the Old World that the United States was now an independent nation, and was no longer to be involved in their quarrels. ${ }^{4}$ Washington's foreign policy became an American heritage. Consistent with his earlier attitude and with the Neutrality Proclamation, Washington bequeathed it to posterity in his Farewell Address. Said the retiring President:

The rule of conduct for us in regard to foreign nations is in extending our commercial relations to have with them as little political connection as possible. So far as we have already formed engagements let them be fulfilled with perfect good faith. Here let us stop.

Europe has a set of primary interests which to us have none or a very remote relation. Hence she must be engaged in frequent controversies, the causes of which are essentially

'Sparks (Jared), The Writings of George Washington, (Boston, 1839), vol. xi, p. 294, Washington to Jefferson, I January, 1788.

'Richardson, (J.D.), Messages and Papers of the Presidents, (Washington, 1896), vol. i, pp. 156-157.

- Channing, op. cit., vol. iv, p. 116.

- Johnson, op. cit., vol. i, pp. 174 et seq. 
foreign to our concerns. Hence, therefore, it must be unwise in us to implicate ourselves by artificial ties in the ordinary vicissitudes of her politics or the ordinary combinations and collisions of her friendships or enmities.

It is our true policy to steer clear of permanent alliances with any portion of the foreign world, so far, I mean, as we are now at liberty to do it; . . .1

Following this policy laid down by the first President, John Adams in a special Message, I6 May, 1797, warned against "involving ourselves in the political system of Europe. ... It would not only be against our interests, but it would be doing wrong to one half of Europe, at least, if we should voluntarily throw ourselves into either scale." 2 Probably this is the first official reference to the "political system " of Europe by an American statesman. ${ }^{3}$

The use of that phrase by President Adarns in 1797, shows an early tendency to draw a distinction between the political organization of Europe and that of the United States. It was a suggestion that the very nature of the difference between the political organization of the Old World and that of the United States was a valid reason for pursuing a policy of isolation.

Thomas Jefferson also made some statements in harmony with the policy of isolation before he became President: "With respect to their government, or policy, as concerning themselves or other nations, we wish not to intermeddle in word or deed, and that it be not understood that our government permits itself to entertain either a will or opinion on the subject." $4 \mathrm{He}$ expressed the same attitude in his

1 Richardson, op. cit., vol. i, pp. 222-223.

3 Ibid., p. 238.

3 Hart, op. cit., p. 13.

4 Ford (P. L.), The Works of Thomas Jefferson, (New York, 1904), vol. vii, p. I05, Jefferson to Pinckney, II June, I792. 
First Inaugural Address: " Kindly separated by nature and a wide Ocean from the exterminating havoc of one quarter of the globe; too high-minded to endure the degradations of the others; possessing a chosen country, with room enough for our descendants to the thousandth and thousandth generation." 1 The same view was expressed in a letter to Thomas Paine, written a few days later. ${ }^{2}$ And in his Message to Congress, I 7 October, I803, Jefferson again referred to the part which nature had played in determining our relations with Europe:

Separated by a wide Ocean from the nations of Europe and from the political interests which entangle them together, with productions and wants which render our commerce and friendship useful to them and their's to us, it cannot be the interest of any to assail us, nor our's to disturb them. ${ }^{3}$

The principle of isolation which had guided Washington and Jefferson in their foreign policy was destined to acquire additional meaning during the administrations of President Madison. Its new meaning consisted in a prohibition against the transfer of American territory from one European power to another. The immediate occasion for this extension of its meaning was furnished by the disturbed conditions in Europe during the Napoleonic wars. In the state of confusion which prevailed there, the fate of the Latin-American colonies hung in the balance. There was grave danger that they might fall into the hands of a power whose strength and influence would be too great for pleasant neighborliness. Moreover, the colonies themselves

2 Richardson, op. cit., vol. i, p. 323.

2 Ford, op. cit., vol. ix, pp. 212-213, Jefferson to Paine, 18 March, I801; Adams (Henry), History of the United States, (New York, 1891), vol. i, p. 214 .

- Richardson, Messages and Papers of the Presidents, vol. i, p. 361. 
soon took advantage of the conditions prevailing in the Spanish peninsula to revolt, not against their rightful king, but against the French domination of Spain. ${ }^{1}$ Chile declared its independence in $18 \mathrm{IO}$, and was followed in this step by Paraguay (I8II), Argentine Confecieration and Buenos Ayres (1816), Great Colombia ( I819), Guatamala, Mexico and Peru (I82I), and Great Bolivia (I825). Brazil declared its independence of Portugal in 1822 and was constituted an empire. The danger of having a strong European neighbor was thus to some extent rendered less probable by the act of the colonies. To the government of the United States the moment seemed opportune for declaring itself opposed to any change of ownership of colonial possessions in America. On 3 January, I8I I, President Madison recommended "to the consideration of Congress the reasonableness of a declaration that the United States could not see without serious inquietude any part of the neighboring territory in which they have in different respects so deep and so just a concern pass from the hands of Spain into those of any other foreign Power." 2

On 3 March of the same year Congress passed a resolution in accordance with the President's recommendation. ${ }^{3}$ The principle of that resolution became afterwards an essential part of the Monroe Doctrine; so that, while the Monroe Doctrine as such was never sanctioned by an act of Congress, a part of it had already passed Congress in the form of a resolution twelve years before President Monroe sent to Congress his memorable Message of 2 December, I823. It must not be supposed that the United

'Shepherd (William R.), The Hispanic Nations of the New World, (New Haven, 1920), p. 17.

2 Richardson, op. cit., p. 488; Hart, op. cit., pp. 27-28; Reddaway (W. F.), The Monroe Doctrine, (New York, Is05), p. 9.

'Annals of Congress, IIth Congress, 3rd Sess., p. 12jt. 
States acted entirely on motives of self-preservation; because the resolution of Congress on 3 March was passed also in response to a desire for the eventual annexation of West Florida. ${ }^{2}$ Nor would it be convenient for the United States to have Florida assume the status of an independent state. $^{2}$

The revolutionary movement in the South American colonies of Spain appealed to the republican sympathies of the United States. If successful it would defeat any designs which European powers might cherish for the transfer of South American territory in Old-World style. The independence of the South American colonies would thus remove a great source of danger to the institutions and prosperity of the United States. The republican tendencies of the revolutionary movement also inspired the hope of saving the western hemisphere from the clutches of the reactionary political system of Europe. The American people beheld with boundless enthusiasm the SpanishAmerican colonies establish political institutions modeled upon their own. ${ }^{3}$

The situation thus produced by the events in South America forced the government of the United States to give further thought to its Latin American policy." Probably the first evidence that the government of the United States expected any new states to arise in South America is furnished in President Madison's Message to Congress in December, $\mathrm{I} 8 \mathrm{I} \mathrm{I}$ :

In contemplating the scenes which distinguish this moment-

1 Reddaway, op. cit., p. 9.

2 Fish (C. R.), American Diplomacy, (New York, 1916), pp. 208209.

- Ibid., p. 206; Hart, op. cit., p. 32.

Uohnson, op. cit., vol. i, p. 320. 
ous epoch, and estimating their claims to our attention, it is impossible to overlook those developing themselves among the great communities which occupy the southern portion of our neighborhood. An enlarged philanthropy and an enlightened forecast concur in imposing on the national councils an obligation to take a deep interest in their destinies, to cherish reciprocal sentiments of good will, to regard the progress of events, and not to be unprepared for whatever order of things may be ultimately established. ${ }^{1}$

A few days later, Io December, a joint resolution was introduced in Congress stating that the United States beheld " with friendly interest the establishment of independent sovereignties by the Spanish provinces in America, consequent upon the actual state of the monarchy to which they belonged," and that when they had "attained the condition of nations" the United States would establish with them " as sovereign and independent states, ... amicable relations and commercial intercourse." 2 Although no action was taken on this resolution, ${ }^{3}$ it expressed not only a growing interest in the affairs of South America, but it also suggested the character of our Latin American policy: it held out the hope of success for the independence movement and the subsequent recognition by the United States.

A number of reasons compelled the exercise of caution in extending recognition to the nascent states of Latin America. In the first place, the government of the United States was not certain that the new states possessed the qualities necessary for self-government." Secondly, the government was of the opinion that hasty action or too open

- Richardson, op. cit., vol. i, p. 494.

- American State Papers, Foreign Relations, vol. iii, p. 538.

- Johnson, op. cit., vol. i, p. 321.

'Johnson, op. cit., vol. i, p. 324. 
a manifestation of sympathy would impede the negotiations with Spain for the acquisition of Florida. ${ }^{1}$ Thirdly, the European war, which was to affect our relations with England, was still going on. Fourthly, the Doctrine of Intervention had not yet caused a rift in the relations of England and her allies. Under such circumstances caution was wisdom.

Meanwhile, a policy of neutrality seemed to recommend itself to our government. In December, I8I5, President Madison issued a proclamation to that effect. ${ }^{2}$ By that act the belligerency of the new states was recognized ${ }^{3}$ before their independence had been fully established." Despite the President's proclamation of neutrality, many American citizens insisted upon extending aid to the South American republics. That fact necessitated the strengthening of our neutrality by acts of Congress in 1817 and $1818 .^{5}$ English subjects, on the other hand, were openly, though unofficially, aiding the revolutionists. ${ }^{\circ}$ The knowledge of English aid must have convinced the American government of the position of England in the South American question. John Quincy Adams, Secretary of State, desirous of British support, ${ }^{7}$ was quick to grasp the significance of that position.

1 Johnson, op. cit., p. 208.

2 Richardson, op. cit., vol. i, pp. 561-562.

- Wilson (G. G.) and Tucker (G.F.), International Law, (Boston, 1915), p. 66; Smith (Sir Frederick), International Law, (London, 1918), p. 192.

- Hart, op. cit., p. 33.

s Annals of Congress, 15th Cong., Ist Sess., vol. i, p. 519; Fish, op. cit., p. 207; Latané (J. H.), The United States and Latin America, (Garden City, 1920), pp. 49-50.

- Phillips (W.A.), The Confederation of Europe, (New York, 1914), p. 260.

7 Fish, op. cit., p. 208; Schurz (C.), Henry Clay, (Boston, 1887), p. 148; Castlereagh, Correspondence, (London, 1853), vol. xi, p. 405. 
In March, 1818, he declared in a Cabinet meeting that in his opinion England was in sympathy with the position of the United States. ${ }^{1}$ Though Adams was opposed to the recognition of the South American republics until after the ratification of the Florida treaty, he was sure that ultimately our government would extend recognition to the new states. $^{2} \quad$ About the same time he gave the British Minister to understand that the United States would cooperate with England in preserving their independence, though he would not promise to enter into any formal alliance with England for that purpose. $^{3}$ Indeed, in August, 1818, a proposal was made to the British government for a concerted recognition of the republic of Buenos Ayres whose independence was then an accomplished fact; ${ }^{4}$ but England declined on the ground that recognition of Buenos Ayres at that time would not be in harmony with her policy. The differences between England and her continental allies had not yet developed to the breaking-point; and so long as there was no immediate danger of interference with either British trade in South America or with the independence of the new. republics, England had little reason for immediate action. It was possible that the course of events would turn so decisively in favor of the South American states as to call for no special exertion in their behalf on the part of England; and in that way she would be spared the danger of diplomatic complications, while at the same time she would enjoy the advantages of her South American trade.

Moreover, it was unlikely that the United States would

Fish, op. cit., p. 208.

Ibid.

Castlereagh, Correspondence, vol. xi, p. 405, Bagot to Castlereagh, 8 February, 1818; ibid., Bagot to Castlereagh, 29 June, 1818; ibid., vol. xii, pp. 99 et seq., Bagot to Cast'ereagh, 4 January, i8r.

4 Johnson, op. cit., vol. i, p. 325. 
alone extend recognition to the new states for some time. Thus the possibility of a political and commercial ascendancy of the United States in the western hemisphere was still remote. England could well afford to delay recognition and await developments. Nevertheless, there is significance in the fact that the governments of the United States and Great Britain had conversed on the expediency of concurrent action relative to the situation in South America. The knowledge which these countries possessed of one another's interest in that region of the world soon suggested another attempt at joint action; but this time the proposal came from England, and it came only after the government of the United States had extended recognition to the new republics of the South, and when England's own interests were jeopardized by the policies of the Quadruple Alliance. ${ }^{1}$

While the administration was pursuing a policy of cautious delay in view of our relations with Spain, the cause of recognition did not lack its leader in Congress. His stern patriotism, hatred of despotism, and his genuine faith in the merits of republican institutions made Henry Clay its stalwart champion. ${ }^{2}$ In the most eloquent terms he pointed out the course which the policy of the United States should take in respect to South America. It was a beautiful country, rich in natural resources, whose inhabitants were struggling to break the shackles of despotism. It was America's mission to encourage them in their noble aims, and to place herself at the head of an American system. In South America were "the loftiest mountains, the most majestic rivers in the world; the richest mines of precious metals; and the choicest productions of the earth. We be-

\section{Supra, p. 10, note.}

2 Annals of Congress, 15th Cong., 1st Sess., vol. ii, p. 1474; Schurz, op. cit., pp. 148 et seq; Latané, op. cit., p. 49. 
hold there a spectacle still more interesting and sublime-the glorious spectacle of eighteen millions of people struggling to burst their chains and be free." 1 Clay's "American system" required that the United States should act independently of Europe in dealing with the South American question. With him the "American system" and cooperation with Europe were mutually exclusive: "We look too much abroad. Let us break those commercial and political fetters; let us no longer watch the nod of any European politician; let us become real and true Americans, and place ourselves at the head of the American System." 2 It was a courageous and patriotic course which Clay proposed for his country; but a little delay in recognition would produce more practical results. Despite the power and eloquence of his appeal, Clay was unable to convince his colleagues in Congress, who in 1818 , by a vote of II 5 to 45 , defeated his motion to recognize the South American republics. ${ }^{3}$

However, within a period of three years after Congress had defeated Clay's motion, circumstances had changed in favor of the course which he had recommended: Metternich's Doctrine of Intervention had served to alienate England from her continental allies, and the Florida treaty had been ratified. ${ }^{4}$ These were the principal elements in the new diplomatic situation which induced President Monroe, 8 March, I822, to recommend to Congress that "the Provinces which have declared their independence and are in the enjoyment of it ought to be recognized." ${ }^{5}$ Within a month Congress had complied with the President's recom-

1 Annals of Congress, I5th Cong., Ist Sess., vol. ii, p. 1474

'Ibid., I6th Congress, Ist Sess., vol. ii, p. 2727.

- Annals of Congress, I5th Cong., Ist Sess., vol. i, p. 1646.

- Am. State Papers, Foreign Relations, vol. v, p. 127.

- Richardson, op. cit., vol. ii, pp. I16 et seq. 
mendation by recognizing Colombia, Argentina, Chile and Mexico. ${ }^{1}$

While recognition had been accorded and a policy of neutrality continued to be maintained by the United States, the permanency of the independence of the new republics might still be endangered by the Metternich school of reactionary statesmanship. It required the combined influence of the United States and Great Britain to guarantee that permanency. The declaration of the Monroe Doctrine and the British policy of non-intervention ${ }^{2}$ were essentially in harmony so far as they constituted a check upon the machinations of the Quadruple Alliance.

We have now traced briefly the gradual development of the Latin American policy of the United States through its successive stages of interest, neutrality and recognition. It was still to experience further growth through the influence of the policy of isolation. But, paradoxical as it may seem, that stage in its history was not to be reached until the government of the United States had become thoroughly familiar with the Latin American policy of Great Britain, especially through Canning's overture to Rush in the interest of a joint Anglo-American declaration.

In the next chapter we shall attempt to explain some of the conditions which determined the change in England's relations to the Quadruple Alliance with a view to finding therein some important reasons for an Anglo-American understanding in 1823 .

1 Annals of Congress, I7th Cong., Ist Sess., vol. i, p. I382.

2 Infra, pp. 34-40, 44-48. 


\section{Great Britain and the Alliances}

THE European statesmen who met in Vienna in 1814 and 1815 to reconstruct Europe on the bases of legitimacy and compensation were blind to the new dynamic forces which had been produced by the intellectual movement of the eighteenth century, by the Industrial Revolution and by the French Revolution. It was a combination of some of these forces which had been responsible for the great upheaval which their countries had just experienced. But so far as they were the "causes" of the long period of war that terminated on the field of Waterloo in 1815 , they were essentially different from causes in the ordinary meaning of the word. Their fundamental character was different. It was not a question of a few more miles of territory, or of additional commercial advantages. They represented great principles of human rights: individual liberty, social equality, national sovereignty. These principles took possession of the human spirit and became the tenets of a people's faith. They grew in the strength of their intrinsic merits and never failed to convince the unprivileged of the justice of their cause. To all who suffered from the trammels of political, economic, and social restrictions and inequalities these principles were the Gospel of freedom that would widen immeasurably the range of opportunity for men, individually and collectively.

As the causes of the European upheaval were so profoundly different from the usual, so must be the remedy. 
In other words, the statesmen who would undertake the solemn and responsible task of reconstructing Europe must open-mindedly and without prejudice investigate the real nature of Europe's "ills." But, alas! the "ills" were "new," and the statesmen were of the old school, who shrank from the arduous task of learning anything new, particularly when it might endanger their own interests. Hence we see the extraordinary spectacle of a group of statesmen vainly attempting to apply 18 th century remedies -remedies of the Ancien Régime-to 19th century conditions-conditions which had their origin in the longing of mankind to be free, a power that proved irresistible.

The very statesmen who concluded the Treaties of Vienna must after all have experienced an inward feeling that they were lacking in harmony with the social and political currents of their time; for they found it necessary to continue in alliance for the purpose of maintaining the status quo for which the treaties provided. And through a series of congresses the Alliance sought means to combat all the forces and tendencies calculated to disturb it. The men of the old order were again in the political saddle, and they would ride roughshod over the principles represented by the French Revolution and the demands of the new economic system.

There was one European state whose situation, political experience and interests failed to harmonize with those of its allies. That state was Great Britain. It was Great Britain where the new economic system was first established; her government was constitutional, founded on revolution; ${ }^{4}$ and she was geographically detached from her continental allies. These circumstances are sufficient to explain the gradual defection of England from the Quadruple Alliance. 
They had given her a set of interests in the pursuit of which she had more to gain by an understanding with the United States than as a member of the European Alliance. From the first of the congresses, that of Aix-la-Chapelle, to the last, the Congress of Verona, England stood opposed to the policy of intervention. In desiring to make the opposition effective she sought an understanding with the United States.

With a view to making clear England's contribution to the declaration of the Monroe Doctrine, it will be necessary to trace her motives as they are revealed in her relations with the Quadruple Alliance and in her interests in Latin America. The original Holy Alliance, ${ }^{1}$ which was the product of the Tsar's religious nature, was but the expression of a pious hope to which the sovereigns of Europe were invited to subscribe. ${ }^{2}$ It was an attempt to capitalize, in the interest of reaction, a wave of religious fervor which swept over Europe as a result of a long period of suffering due to violence and strife. At any rate, the signatories 10 the Holy Alliance were convinced "of the necessity of settling the steps to be observed by the Powers, in their reciprocal relations, upon the sublime truths which the Holy Religion of our Saviour teaches." 3 The English sovereign was naturally invited to becone a member of this "most free and most intimate Union between the Sovereigns whom Divine Providence has placed over the heads of the Peoples of Europe." 4 Of course it would have been

1 The term "Holy Alliance" is here used in its true and original meaning.

'Hayes (C. J. H.), A Political and Social History of Modern Europe, (New York, 1916), vol. ii, p. II.

' Hertslet (E.), The Map of Europe by Treaty, (London, 1875), vol. i, pp. 317 et seq.

4 Hertslet, op. cit., vol. i, pp. 319-320. 
strange, if not indicative of a want of religious reverence, had not the Prince Regent declared his "entire concurrence in the principles they have laid down, and in the declaration which they have set forth, of making the Divine Precepts of the Christian Religion the invariable rule of their conduct, in all their relations, social and political." ${ }^{1}$ That was scarcely more than what any sovereign of a Christian state might be expected to do. A treaty to that effect would only be superfluous if the spirit of Christ ruled in their hearts, and, if not, a treaty providing for Christian conduct would fall quite short of being effective. Whatever may have been the other motives which determined the attitude of the British government in this instance, at least one reason for its refusal to join the Holy Alliance is made very plain in the reply that was sent by the Prince Regent: "... the forms of the British Constitution, which I am called upon to administer in the name and in the behalf of the King, my father, preclude me from acceding formally to this Treaty." 2 The Monarchs of Russia, Austria and Prussia in the haste to restore the old order had evidently ignored the fact that constitutional limitations restricted the freedom of action of British monarchs, though they were still termed gratia Dei reges. In actual practice Parliamentary government had taken the place of government by Divine Right, and the English monarch could not, therefore, join in an alliance apparently bottomed on that outworn theory. Judging by Tsar Alexander's own liberalism, the Holy Alliance may not have represented a conscious purpose of fastening upon Europe a system of reaction; ${ }^{3}$ but the vague, indefinite, and conservative tone

1 Hertslet, op. cit., p. 320.

is: 1 bid.

${ }^{3}$ Phillips, op. cit., p. 149. 
of the treaty gave to it a character susceptible of such an interpretation whenever the opportunity might arise. Alexander's immediate aim seems to have been the establishment of a union or league of European States for the sake of maintaining peace. ${ }^{1}$ Upon the common ground of a desire for peace the union might possibly be effected. Having once secured the signatures of the sovereign authorities to the treaty of the Holy Alliance, ${ }^{2}$ the building of the Pan-European structure upon that foundation would probably not be so difficult.

The system suggested by the Holy Alliance would soon develop into a substitute for that system which Napoleon had tried to establish, and which Great Britain had exerted herself to the limit to destroy. Immediately suspicious of its purposes she declined membership in the Holy Alliance on the ground of constitutional limitations. ${ }^{3}$ Against the plan of the Tsar for a Pan-European union of states, Great Britain took her stand on the principle of the independence of sovereign states. ${ }^{4}$ To England a concert for the enforcement of the Treaties of Vienna was quite necessary and practical; but it was a wholly different matter to establish an international combination that might interfere with the sovereign independence of a state, even when the exercise of that sovereignty was confined to the solution of questions touching internal organization. The unwillingness of England to accede to the treaty of the Holy Alliance, ${ }^{5}$ coupled with the peculiar vagueness and dreamy idealism of its aims rendered that alliance incapable

1 Phillips, op. cit., p. I5I.

2 Supra, p. 32, note $\mathrm{I}$.

${ }^{3}$ Hertslet, op. cit., vol. i, p. 320.

- Phillips, op. cit., p. I52; cf. ibid., pp. 30-40.

5 Supra, p. 32, note I; supra, p. 10, n. I. 
of functioning from the beginning. But the Allies had in March, I8I4, concluded the Treaty of Chaumont ${ }^{1}$ for the double purpose of providing for the vigorous prosecution of the war against their common enemy and for the maintenance of peace in the future. It was renewed, with some modifications, as the Treaty of the Quadruple Alliance, 20 November, I8I $5 .^{2}$ In the popular mind the two alliances became confused, the Quadruple Alliance usually being referred to as the Holy Alliance. Justification for that error may be found in the fact that the aims of three members of the Quadruple Alliance became essentially the same as those of the Holy Alliance.

In the discussion at Paris which related to the renewal of the Quadruple Alliance is revealed a divergence of opinion between Great Britain and her allies. ${ }^{3}$ While the latter seemed to agree on the draft of the treaty drawn up by Tsar Alexander, which provided for an inquisitorial supervision over the internal affairs of a state, ${ }^{4}$ Castlereagh, representing England, emphatically opposed a treaty of that nature. He was unable to see how the policy which they prescribed for the safety of their own countries made necessary any! interference with the internal affairs of any state. Broadening out from precedent to precedent such a policy would lead to an impairment of national sovereignty. ${ }^{5}$ Continental internationalism came thus into conflict with English nationalism in the Congress of Paris, and Castlereagh was able to force a modification of the treaty.

1 Hertslet, op. cit., vol. iii, p. 2043.

I Ibid., vol. i, p. 372 .

${ }^{3}$ Phillips, op. cit., p. I53.

4 At that time it was France that was the special object of suspicion.

${ }^{5} \mathrm{~F}$. O., Congress, Paris, Castlereagh to Liverpool, I5 October, I8I5, no. 80 . 
The Treaty of the Quadruple Alliance as agreed upon by the four powers, England, Russia, Prussia and Austria, expressed a desire on the part of the four sovereigns "to draw closer the ties which unite them for the common interests of their people," and to resolve "to give to the principles solemnly laid down in the Treaties of Chaumont and Vienna, the application, the most analogous to the present state of affairs." 1 The treaty further provided for concerted action in carrying out the second Treaty of Paris, and for taking measures against such revolutionary outbreaks as might threaten the safety of their own states. It stipulated that the engagements thus entered into should continue in force beyond the period of temporary occupation of France. Lastly, in article vi, it provided for " meetings at fixed periods, either under the immediate auspices of the sovereigns themselves, or by their respective Ministers, for the purpose of consulting upon their common interests, and for the consideration of the measures which at each of those periods shall be considered the most salutary for the repose and prosperity of Nations, and for the maintenance of the peace of Europe." 2

Such was the basis upon which the conquerors of Napoleon proposed to guarantee the peace of Europe. But article vi was a compromise between English Realpolitik and the Tsar's idealism; and, like so many other compromises, it was sufficiently vague to admit of different interpretations. ${ }^{3}$ Therein lurked a danger to the permanent success of the Quadruple Alliance.

The first Congress of the Alliance assembled at Aix-laChapelle on 30 September, I818. The sovereigns of

1 Hertslet, op. cit., vol. i, p. 372.

Hertslet, op. cit., vol. i, p. 375.

Phillips, op. cit., pp. I55-156. 
Austria, Russia and Prussia considered the meeting sufficiently important to require their august presence; while England was represented by Castlereagh and Wellington.

By far the most important question which arose in the Congress was the one relating to the future aim and activity of the Quadruple Alliance. ${ }^{1} \quad$ Upon the answer to this question would depend the position of England in the Alliance. Upon it also would depend the effectiveness of the Alliance itself.

England had already refused to join the Holy Alliance; ${ }^{2}$ and Castlereagh had obtained a modification of the draft of the Treaty of the Quadruple Alliance. ${ }^{3}$ At the Congress of Aix-la-Chapelle British statesmen again opposed any designs of the Alliance to constitute itself a Pan-European power.

A memorandum, ${ }^{4}$ embodying the views of Tsar Alexander on the measures that should be employed to protect Europe from further outbreaks of revolution, was presented to the Congress. It pointed out that the system of Europe was an association of powers founded upon the treaties of Vienna and Paris for the purpose of preserving all recognized rights. The material support of that association had been the army of occupation in France; but now that the powers had decided to evacuate France, the European system must find compensating strength in the increase of its moral support, which the Tsar found in the Quadruple Alliance and the General Alliance. ${ }^{5}$ The Quadruple Alliance was to be at the same time the nucleus and the basis of the

1 Phillips, op. cit., pp. 167-168.

${ }^{2}$ Supra, p. 33.

3 Hertslet, op. cit., vol. i, p. 372.

${ }^{4}$ F. O., Continent, Aix-la-Chapelle, September-October, I818, Castlereagh to Bathurst, 19 October, $18 \mathrm{I} 8$, no. 13 .

s The General Alliance was to consist of all the powers signatories to the Treaties of Vienna. 
General Alliance. The purpose of the entire organization was to guarantee the territorial integrity of the states and the security of their governments. Here was clearly a plan to construct a political system which would not merely preserve the territorial status quo as created by the peace treaties, but which also foreshadowed the policy of intervention. To such a plan both the government and public opinion in England were opposed. ${ }^{1}$ Even before the Russian Memorandum had been presented to the Congress, Lord Bathurst had written a letter to Castlereagh, in which he expressed his objection to a "succession of such meetings being now proclaimed as a part of a permanent system;" because "though the mind might anticipate further circumstances under which such meetings might be productive of many advantages, one may likewise contemplate those under which they might be likely to lead to great embarrassment." ${ }_{2}$ As for article vi of the treaty of 20 November, I8I5, Lord Bathurst would prefer to leave it in abeyance. ${ }^{3}$ In opposition to the plan of universal union contained in the Russian Memorandum, Castlereagh presented in turn a Memorandum in which he defined the attitude of England. ${ }^{4}$ According to Castlereagh, the provisions of the treaties concluding the Napoleonic wars were for the most part territorial; no provision was made for their observance, and since the treaties did not provide for an alliance, no power was under express obligation to compel their observance. However, the Treaty of Chaumont, renewed at Paris 20 November, I8I5, was an alliance treaty for the protection

${ }^{1}$ Phillips, op. cit., pp. 173-174.

${ }^{2} F$. O., Continent, Aix-la-Chapelle, September-December, I8r8, Bathurst to Castlereagh, 20 October, 1818.

s Ibid.

4 Ibid., September and October, I8I8, Castlereagh to Liverpool, '19 October, 1818 , no. 13 . 
of Europe against renewed danger from France; but under no circumstances was it intended to give the Allies the right to interfere in the internal affairs of that country, or any other country, unless the internal disturbance was of such a nature as to threaten the safety of other states. The latter contingency would be covered sufficiently by the lawt of nations." It was both " immoral" and "prejudicial to the character of government" to lend support to established power, "without any consideration of the extent to which it was abused." 2

The emphatic expression of England's attitude in this Memorandum prevented the successful consummation of the Tsar's illusory scheme of a universal union of European states. The most that he could hope for was a compromise couched in terms sufficiently vague as to admit of some elasticity of interpretation. ${ }^{3}$ The outcome of the deliberations at Aix-la-Chapelle was a limitation on the operation of article vi of the Treaty of Paris of 20 November, I8I 5 . It was now to be restricted to the enforcement of the treaties that were especially enumerated in that document." Any new treaty of alliance failed to materialize because of the opposition of England. ${ }^{5}$ Future meetings of the sovereigns or their representatives were to be confined to questions that might arise out of these treaties, and the meetings were to be called only as occasion might require. ${ }^{6}$ Thus the authority of the Quadruple Alliance was to be

1 F. O., op. cit., ibid.

Ibid.

- Phillips, op. cit., p. I88.

4 Hertslet, op. cit., vol. i, pp. 573-574; F. O., Continent, September-December, I8I8, Castlereagh to Bathurst, 5 November, I818.

5 Ibid., Continent, Aix-la-Chapelle, September-December, I818, Bathurst to Castlereagh, I3 November, I8I8, no. 6.

- Ibid., Castlereagh to Bathurst, 5 November, I8r8. 
limited to questions that might arise out of conditions and circumstances already well known. It was not to embrace questions that might arise out of circumstances entirely unforeseen. In other words, the Alliance was not to be a universal union for the governing of Europe,- - an international substitute for national sovereignty.

Not only were the English representatives at the Congress of Aix-la-Chapelle opposed to the extension of its authority to questions growing out of circumstances then unforeseen, ${ }^{1}$ but they were already opposed to intervention in Spain, ${ }^{2}$ and to any consideration of the relation of Spain to her American colonies. ${ }^{3}$

One member of the British Cabinet was opposed on principle even to the idea of periodic meetings. ${ }^{4}$ That was Canning. He feared that England would thereby become too deeply involved in continental politics, "whereas our true policy has always been not to interfere except in great emergencies, and then with a commanding force." 5

The compromise effected at Aix-la-Chapelle was clearly an English diplomatic victory-a triumph for non-interference. When presently the fear of revolutionary outbreaks led to actual intervention in the internal affairs of states, England again rallied consistently to the defense of this principle; but the result, instead of being a compromise, became a breach.

The revolutionary outbreaks in Spain, Naples, Piedmont

Wellington, Supplementary Despatches, (London, I858-72), vol. xii, p. 675 .

Wellington, op. cit., vol. xii, p. 665.

3 Castlereagh, Correspondence, vol. xi, p. 473, Cooke to Castlereagh, 28 August, 1818.

- Temperley (H. W. V.), George Canning, (London, I905), p. 180.

5 Castlereagh, op. cit., vol. xii, p. 56, Bathurst to Castlereagh, 20 October, I8I8. 
and Portugal in I820, conveyed an ominous meaning to the sovereigns of Austria, Russia and Prussia. Alarmed by these events, as well as by the lukewarm enthusiasm of Great Britain for the Quadruple Alliance, ${ }^{1}$ a call was issued for a meeting of the Alliance ${ }^{2}$ to be held at Troppau. It was to become revitalized through active opposition to the revolutionary movement. ${ }^{3}$ Here again the differences between the attitude of England and that of her continental allies, on the question of authority, became conspicuous. Despite the setback which the Tsar's plan for a universal union had received through British influence at the Congress of Aix-la-Chapelle, he still entertained dreams of its ultimate realization. This is shown in a circular issued by the Russian government I9 April, I820, containing expressions which indicate an enlargement of the plan: "The Spanish Revolution fixes the attention of the two worlds; the interests to be decided are those of the universe .... and involve the future perhaps of all civilized peoples." " The world-wide scope of the plan, and the Tsar's hope of its realization, had evidently been inspired by events in South America. These events showed that the conflict of the two political systems threatened to assume large proportions. Hence, the suggestion in the same circular that the Ministers of the allied nations should hold a meeting at Madrid preparatory to intervention. ${ }^{5}$ The circular also contained

1 F. O., Austria, March-June, 1820, Stewart to Castlereagh, 9 April, I820, no. 43; ibid., Stewart to Castlereagh, 4 May, I820, no. 55; ibid., Stewart to Castlereagh, 23 May, 1820, no. 57.

'F. O., Circular Despatches, 1815, 1818, 1820, Austrian Memoir on the Revolution at Naples, 28 August, 1820.

${ }^{3}$ F. O., Austria, March-June, 1820, Stewart to Castlereagh, 9 April, 1820, no. 43. 1820.

4 F. O., Austria, March-June, I820, Nesselrode to Galowkin, I9 April,

I lbid. 
statements showing the Tsar's opposition to constitutional governments. ${ }^{1}$

While the allied courts were considering the Russian circular, and England was showing herself most unsympathetic, ${ }^{2}$ a revolution broke out in Naples 2 July, 1820 . In reply to the Russian circular note which represented an attempt to revive the plan of a universal union, Castlereagh despatched a note to the courts of Austria, France, Prussia and Russia, saying that

it was an union for the reconquest and liberation of a great proportion of the continent of Europe from the military domination of France; and having subdued the conqueror, it took the state of possession, as established by the peace, under the protection of the Alliance. It never was, however, intended as an union for the Government of the world, or for the superintendence of the internal affairs of other States. ${ }^{3}$

The Neapolitan movement was of peculiar interest to Austria, because a political change in that kingdom would actually violate the secret treaty between Austria and Naples, dated I2 June, I8I 5. ${ }^{4}$ The government of England took the view that it lay within Austria's right to deal with the Neapolitan revolution; ${ }^{5}$ but Castlereagh refused to give the "moral support" which Austria sought to obtain, on the ground that England would not interfere in the affairs

1 F. O., op. cit., ibid.

Phillips, op. cit., p. 208.

- Parl. Papers, vol. xix, p. 7I, Castlereagh to the courts of Austria, France, Prussia and Russia, May, 1820.

-F. O., Continent, Circular Despatches, 1815, 1818, 1820, Austrian Memoir on the Revolution at Naples, 28 August, 1820; Phillips, op. cit., p. 210.

${ }^{5}$ Ibid., F. O., Continental Circular Despatches, 1815, 1818, 1820, Castlereagh to Stewart, 29 July, 1820, no. I3. 
of Naples even to the extent of encouraging other states to do so. ${ }^{1}$ Failing to obtain the moral support of England in his Neapolitan venture, Metternich resorted to calling a new congress of the Quadruple Alliance. ${ }^{2}$ It assembled at Troppau in October, I820. The very situation which had occasioned the assembling of the congress furnished sufficient evidence of what was to be its most important business. It was plain to the government of England that once again an attempt was to be made to erect the Alliance into a European political system with the authority to intervene in the domestic affairs of the states. ${ }^{3}$ Accordingly, England sent no official representatives; but instructed Lord Stewart, the British ambassador at Vienna, to be present as an observer."

In a letter to Stewart, Castlereagh again expressed his opposition to intervention in any independent state distracted by "internal convulsions" :

With the respect and attachment which I feel for the system of the Alliance as regulated by the transaction of Aix-laChapelle, I should much question the precedence, or, in truth, the efficacy, of any formal exercise of its forms and provisions on the present occasion when the danger springs from

1 Ibid., Castlereagh to Stewart, I9 July, I820; ibid., I6 September, I820.

2 Ibid., Austrian Memoir on the Revolution at Naples, 28 August, I820; ibid., Russia, May-October, I820; Bagot to Castlereagh, I6 September, I820, no. 22 ; ibid., Bagot to Castlereagh, 25 September, I8zo, no. 24 .

3F. O., Continent, Circular Despatches, 1815, 1818, I820, Castlereagh to Stewart, 16 September, I820; Phillips, op. cit., p. 216.

$4 F$. O., Circular Despatches, I815, I818, 1820, Castlereagh to Stewart, I6 September, 1820, no. I9; $c f$. ibid., Castlereagh to Stewart, I6 December, I820; Snow (F.), Treaties and Topics in American Diplomacy, (Boston, I894), p. 24I. 
the internal convulsions of independent states, the policy of hazarding such a step is much more questionable. ${ }^{1}$

The British Parliament would be certain to disapprove any course taken by the government that would bind England to any such engagements. ${ }^{2}$

Since neither England nor France, the two constitutional states in the Alliance, had given to its representatives at Troppau plenary powers, the results of the congress as embodied in its "Protocol" and as indicated by the invasion of Naples and Piedmont by Austrian troops, was largely the work of the three autocratic powers, Russia, Austria and Prussia. ${ }^{3}$ Their policy of intervention was clearly set forth in the Troppau Protocol in the followingt terms :

States which have undergone a change of Government due to revolution, the results of which threaten other states, ipso facto cease to be members of the European Alliance, and remain excluded from it until their situation gives guarantees for legal order and stability. If, owing to such alterations, immediate danger threatens other states, the Powers bind themselves, by peaceful means, or if need be by arms, to bring back the guilty state into the bosom of the Great Alliance. ${ }^{4}$

In order to remove the "erroneous impressions of the

${ }^{1}$ Castlereagh, Correspondence, vol. xii, p. 312, Castlereagh to Stewart, I6 September, I820; cf. F. O., Continent, Circular Despatches, I8I5, 1818, I820, note presented by British ambassador at Troppau.

2 Castlereagh, Correspondence, vol. xii, p. 3I4.

${ }^{3}$ F. O., Austria, Lord Stewart, March-September, I821, Stewart to Castlereagh, 20 March, I821.

4 British and Foreign State Papers, vol. viii, pp. II 49 et seq.; F. O., Continent, Circular Despatches, 1815, 1818, I820, Protocol Preliminaire, I9 November, I820; ibid., Troppau Circular, 8 December, I820. 
past" which the Protocol might give, Castlereagh drew up the Circular of I9 January, I82I, and despatched it to the British representatives at foreign courts. It defined in unmistakable terms the attitude of the British government toward the Congress of Troppau. Against the policy of intervening in the domestic concerns of independent states the government of England protested that

they do not regard the Alliance as entitled, under existing treaties, to assume, in their character as Allies, any such general powers, nor do they conceive that such extraordinary powers could be assumed, in virtue of any fresh diplomatic transaction amongst the allied courts, without their either attributing to themselves a supremacy incompatible with the rights of other states, or, if to be acquired through the special accession of such states, without introducing a federative system in Europe, not only unwieldy and ineffectual to its object, but leading to many most serious inconveniences. ${ }^{1}$

England had never understood the treaties of Vienna and Paris as having placed any such obligations upon the signatory powers as the Congress of Troppau had assumed; ${ }^{2}$ nor could the British government admit that the right to interfere in the internal affairs of an independent state could " receive a general and indiscriminate application to all Revolutionary Movements, without reference to their immediate bearing upon some particular state or States, or be made prospectively the basis of an alliance." 3

$1 F$. O., Continent, Circular Despatches, 1815, 1818, 1820, Castlereagh, Circular Despatch to His Majesty's Missions at Foreign Courts, I9 January, I82I; British and Foreign State Papers, vol. vii, pp. II60 et seq., Castlereagh to British Ministers at Foreign Courts, I9 January, I82I ; Hertslet, op. cit., vol. i, pp. 664 et seq.

I Ibid.

${ }^{3}$ Ibid.; cf. F. O., Continent, Circular Despatches, 1815, 1818, 1820, Castlereagh to Stewart, I6 December, I820, no. 32. 
Moreover, interference in the affairs of an independent state would be fraught with great dangers : it would increase the popular suspicion and distrust of the rulers, and would thereby stimulate revolutionary agitation; if successful, it would "destroy all wholesome national energy." "

Consistent with her earlier policy, England became increasingly outspoken in her opposition to intervention. Hers was the narrow and strict interpretation of the treaty. of the Quadruple Alliance, and her statesmen continued to employ their efforts to limit the authority of the Alliance to questions which grew directly out of the treaties enumerated therein.

Having given formal expression to the principle of intervention, the Allies proceeded to give it practical application. The opportunity for so doing was afforded by the revolutionary movements in Naples and Piedmont in 1820. Austria was commissioned to intervene, and her arms were completely successful in restoring the reactionary kings of Naples and Piedmont to their respective thrones.

Inflated with the pride of success the Alliance sought the application of their principle to Spain, where a revolution had also broken out in I820. The Spanish revolutionists had forced the king to accept the Constitution of I8I2; but Ferdinand VII did not expect long to remain in so uncomfortable a political strait-jacket, especially since there were sympathetic fellow-monarchs from whom help might be obtained to effect his release. Appeal was accordingly made to the allied monarchs. The latter agreed to meet at Verona in 1822, where, in accordance with the principle of intervention, steps would be taken to help Ferdinand to regain his former position.

Just on the eve of the Congress of Verona, George Cann- 
ing was promoted to the office of Secretary of Foreign Affairs, the position left vacant by the death of Castlereagh. ${ }^{1}$ A change of incumbent did not produce any abrupt change in foreign policy. ${ }^{2}$ If anything, England's divergence from the policy of the Alliance became more pronounced until it resulted in a complete break over the Spanish-American question.

England had too many interests at stake among the numerous matters which were to come before the Congress of Verona not to take an active part in its deliberations. ${ }^{3}$ It had been Castlereagh's plan to attend in person. That mission was now entrusted to the Duke of Wellington, ${ }^{4}$ who proceeded to Verona armed with a Memorandum which Castlereagh had drawn up for his own guidance. ${ }^{5}$ It contained the following instructions:

If there be a determined project to interfere by force or by menace in the present struggle in Spain, so convinced are His Majesty's government of the uselessness and danger of any such interference-so objectionable does it appear to them in principle, as well as utterly impracticable in execution, that when the necessity arises, or (I would rather say) when the opportunity offers, I am to instruct your grace at once frankly and peremptorily to declare, that to any interference, come what may, His Majesty will not be a party. ${ }^{6}$

1 Phillips, op. cit., p. 243.

2 Broderick (G. C.) and Fotheringham (J. K.), A History of England, (London, I906), vol. xi, p. 216.

3 Snow, op. cit., p. $24 \mathrm{I}$.

-F. O., Continent, Verona, September-December, I822, Canning to Wellington, I4 September, I822.

- Ibid., Memorandum of Instructions.

- Ibid., Canning to Wellington, 27 September, I822, no. 4; Parliamentary Papers, (1823), vol. xix, p. 2, Canning to Wellington, 27 September, I822; Stapleton (A. G.), The Political Life of the Right Honourable George Canning, (London, I83I), vol. i, pp. I45 et seq. 
The Spanish question assumed an overshadowing importance above all other questions before the congress; and it was the question in which England had the greatest interest." It practically monopolized the attention of the congress. ${ }^{2}$

Despite the known attitude of England, the other members of the Alliance proceeded to take steps for intervention in Spain with a view to restoring Ferdinand VII as an autocratic ruler. After considerable diplomatic wrangling as to the best method of procedure, and as to what member of the Alliance should be authorized to intervene on its behalf, the congress decided in favor of France. ${ }^{3}$ Meanwhile, Wellington, in accordance with Canning's instructions, had labored against the plan of intervention. ${ }^{4}$ The determined attitude of the other powers caused Wellington to withdraw: from the congress, ${ }^{5}$ refusing also to sign the procès verbaux. ${ }^{6}$ The break between England and her allies, which had long been in preparation through a growing divergence of views, now became complete; ${ }^{7}$ and England was left free to pursue a policy more in harmony with her own

1 Cambridge Mod. History, vol. x, p. 33.

Ibid., p. 34 .

3 British and Foreign State Papers, vol. x, p. 921 ; Stapleton, op. cit., vol. i, p. I53.

-F. O., Continent, Verona, September and October, I8z2, Wellington to Canning, 29 October, I822, no. I8; ibid., November, I822, Wellington Memoranda, no. 20; Stapleton, op. cit., vol. i, p. I54.

- F. O., Continent, Verona, November and December, 1822, Wellington to Nesselrode, 29 November, I822, no. 4I; Phillips, op. cit., p. 274.

- Parliamentary Papers, (I823), vol. xix, p. 57, Canning to Stewart, 31 March, I823; F. O., Continent, Verona, November, I822, Wellington, Minute of Observation on Procès Verbaux; ibid., 27 November, Wellington, Memorandum of Interview with the Russian Emperor.

${ }^{5} \mathrm{Ibid}$., November and December, 1822, Wellington, Memorandum, 27 November, I8z2, no. 42; Parliamentary Papers, vol. xix, p. 8; Ibid., pp. 26 et seq.; cf. Hansard, Parl. Debates (n. s.) vol. viii, pp. 872 et seq. 
interests. ${ }^{1}$ But it was not England that was responsible for the breach in the Alliance. Her government merely continued to maintain consistently its opposition to a European dictatorship in the internal affairs of sovereign and independent states, for which the treaty of alliance of 20 November, 1815, furnished no warrant. It was instead the Alliance which had, according to Castlereagh, ${ }^{2}$ moved "away from us without our having quitted it."

The history of the relations of England and her continental allies from 1815 to 1822 reveals not only a conflict between two political systems; but also a difference in the conception of the right of an individual state to self-expression and political growth. England was a constitutional monarchy, and had herself experienced political revolution; ${ }^{3}$ while her allies, with the exception of France, were autocratic states - fearful of the consequences of any political change, save when handed down from above." Naturally, England neither could nor would oppose ${ }^{5}$ or be a party to the suppression of any movement occurring within a state, which had for its ultimate aim the establishment of pritical institutions akin to her very own, especially when such a movement confined itself within the boundaries of the suvereign state in question. So far, England's policy of nonintervention had its source in an attitude produced by her own political experiences and in a strict interpretation of the treaty of 20 November, I8I5. However, additional emphasis was given to that policy when the Alliance pro-

1 F. O., Continent, Verona, November and December, 1822 , Wellington to Canning, 29 November, I822, no. 45 .

- Ibid., Austria, Domestic, September-December, 1820, Report of Esterhazy, October, I820; Cambridge Mod. History, vol. x, pp. 36 et seq.

3 McLaughlin, op. cit., pp. II3, II6.

- Phillips, op. cit., p. 216.

- Stapleton, George Canning and His Times, (London, 1859), pp. 378-79. 
posed to intervene in Spain and threatened to intervene in the Spanish-American colonies; because in so doing, not only would the balance of power be upset, but England's commercial interests would be jeopardized. ${ }^{1}$

Confronted still by the same task - that of presenting an effective opposition to intervention - only grown larger, more difficult of accomplishment, and never so urgent of decisive results, England felt the necessity of gathering her forces for a supreme achievement.

${ }^{1}$ Henderson (J. B.), American Diplomatic Questions, (New York, 1901), p. 313 . 


\section{CHAPTER III \\ INTERVENTION IN Spain}

THE foreign policy of George Canning was essentially a continuation of that of his predecessor, ${ }^{1}$ being characterized only by a more determined effort to free England from the European Alliance. The interests of England were always to be consulted in preference to the interests of the Alliance, in shaping the course of England's foreign policy. ${ }^{2}$ There is, therefore, some justification for the statement of Canning's biographer that Canning was the originator of a really "British Policy," and reduced it to a system. $^{3}$

As a member of Lord Liverpool's Cabinet before becoming Foreign Minister, Canning had become familiar with the nature of England's relations with the continent; and he had opposed altogether the idea of congresses." In the autumn of 1823 he wrote to Wellington what he considered to have been the purpose of the Alliance from the beginning. His statement is in substantial agreement with Castlereagh's protest $^{5}$ against the Troppau Protocol, ${ }^{8}$ thus showing the

1 Phillips (W. A.), The Confederation of Europe, p. 244.

3 Stapleton, Life of Canning, vol. i, p. 134.

3 lbid., pp. 474-475.

4 Castlereagh, Correspondence, vol. xii, p. 56, Bathurst to Castlereagh, 20 October, 1818.

- Hertslet, The Map of Europe by Treaty, vol. i, p. 664.

I Ibid., p. 658; F. O., Continent, Circular Despatches, 1815, 1818, 1820, Troppau Circular, 8 December, 1820. 
continuity of England's foreign policy. Metternich, he says, "contends in effect, if not in so many words, that the Alliance was framed against the dangers of internal revolution; he admits, I presume, that it was also framed against ambitious aggression from without. We contend that it was framed wholly against the latter danger, with the single exception of a Buonapartean revolution in France." 1 Not only would Canning refuse to support the actions of the Alliance based upon an interpretation of its purpose so much at variance with that of the British government; but he would try to render the Alliance ineffective. ${ }^{2}$ Rendered ineffective, it would soon lose its raison d'ĉtre and be dissolved. To that extent Canning's attitude reflected a new development in British policy, foreshadowed, but not directly aimed at, by that of Castlereagh.

In pursuing this course toward the Alliance, it cannot be said that Canning was moved wholly by a love of political liberalism. His own political convictions were those of monarchism. What he objected to, no matter what the form of government of a state, was foreign interference with that government, established or in process of change. ${ }^{4}$ He was quick to discern that Europe was experiencing a conflict between monarchy and democracy. In a speech which he delivered in Liverpool shortly before assuming the office of Foreign Minister he made that fact plain; and, though he could not then have thought of himself as about to be called to the Foreign Office, he suggested the course which his country should pursue in the presence of such a conflict:

'Stapleton, George Canning and His Times, p. 376.

2 Stapleton, Life of Canning, vol. i, p. 135.

Ibid., p. 485.

4 Ibid., pp. 485-486; George Canning and His Times, p. 380 . 
Gentlemen, in the time in which we live there is (disguise it how we may) a struggle going on-in some countries an open, in some a tacit struggle-between the principles of monarchy and democracy. God be praised that in that struggle we have not any part to take. God be praised that we have long ago arrived at all the blessings that are to be derived from that which alone can end that struggle beneficially-a compromise and intermixture of those conflicting principles. It is not, as it appears to me, the duty of this country to side either with the assailants when they aim at too much, nor with those who stand upon the defensive, when they will grant nothing. England has only to maintain herself on the basis of her own solid and settled Constitution, firm, unshaken-a spectatress interested in the contest only by her sympathies; not a partisan on either side, but, for the sake of both, a model, and ultimately an umpire. ${ }^{1}$

Neutrality in such a conflict would improve the position of England, keep from her shores the danger of foreign war, and protect her own institutions. ${ }^{2}$ The scenes of the French Revolution, still clear in his mind, and his own experiences with the champions of reaction, must have convinced Canning of the danger of siding with the party of either extreme, had he been privileged to exercise his choice. He was equally persuaded of the wisdom of neutrality; because thereby he might maintain the political equilibrium of Europe by a nice balancing of diplomatic influence. ${ }^{3}$

It was clever diplomatic balancing of British influence that scored a triumph at the Congress of Verona. By her refusal to be a party to a joint attack on Spain, England frustrated the plan of the Alliance for corporate action

1 Stapleton, George Canning and His Times, p. 368.

2 lbid.

- Stapleton, Life of Canning, vol. i, pp. 135, 474.

-Ibid., pp. 334, 476; Hansard, vol. viii, p. I483; Parliamentary Papers, (I\&23), vol. xix, pp. 7 et seq.; Marriott (J. A. R.), George Canning and His Times, (London, 1903), p. 95. 
which the Tsar desired. ${ }^{1}$ This success may not have been due so much to diplomatic persuasion as to the fear of what England would do to prevent it. ${ }^{2}$ Reducing the scope of the impending conflict between the Alliance and the Spanish Constitutionalists, so as to limit it to a quarrel between France and Spain, ${ }^{3}$ had more than ordinary significance. Although it seemed likely that France would make an attack upon the Spanish Constitutionalists, France alone might easily be prevented from going to such lengths in her relations with Spain as to injure England's interests; whereas, if corporate action had taken place, England would have found herself correspondingly weaker in bargaining for her rights at the conclusion of the war.

The relation of Spain and the Alliance having been reduced to a question of war between Spain and France," Canning could carry one step farther his plan for rendering the influence of the Alliance ineffective; he would prevent the outbreak of war which grew more and more threatening. The means which he sought to employ in the interest of peace was mediation. ${ }^{5}$ An offer of mediation was accordingly made to the French government; ${ }^{b}$ and if accepted; Canning's aim to maintain the peace of Europe by dissent-

'F. O., Continent, Verona, November, I822, Wellington to Canning, I9 November, 1822, no. 25.

Stapleton, Life of Canning, vol. ii, p. 37 ; cf. F. O., Continent, Verona, November, 1822, Wellington to Canning, 29 November, I822, no. 32.

s Canning, Specches, vol. v, p. 16.

${ }^{4}$ F. O., Spain, September-December, I822, Canning to William a Cuurt, 9 December, I822, no. 32 ; Hansard, vol. viii, p. 882.

SIbid., pp. 881, 883; F. O., Contincnt, Verona, September-December, 1822, Canning to Wellington, 6 December, 1822, no. 24; Stapleton, Life of Canning, vol. i, pp. 220, 476.

- Ibid., vol. i, p. 220; F. O., Continent, Verona, November and December, 1822, no. 60, note; Parliamentary Papers, (1823), vol. xix, p. 13. Wellington to Montmorency, I7 December, 1822. 
ing from the policy of the Alliance would have been realized." But while Canning found hope of success in the fact that France was to act singly against Spain, Montmorency, the French representative at the Congress of Verona, declined the offer of mediation on the ground that, after all, the Spanish question was "wholly European." 2 That was evidently an excuse for not wishing to accept the British offer, because such acceptance would not suit the convenience of the French government in the pursuit of its Spanish policy. However, the French Cabinet was not unanimous in its interpretation of the question. Villèle, the Prime Minister, took the view that the question was "wholly French," ${ }^{3}$ and with him sided the majority of the Ministry. Nevertheless, the war party had its way.

That France was maneuvering for individual advantage without regard for the Alliance is shown in her independent action in dealing with Spain. The four powers - France, Austria, Prussia and Russia - had decided at Verona ${ }^{*}$ that they would send similar notes to Madrid based upon the Verona proceedings. The French government, having taken the position that the question was "wholly French," sought to steal a march on the Allies. ${ }^{5}$ Not only was the French despatch based upon that interpretation of the Spanish question, but it was more conciliatory in tone than were

1 Canning, Memoirs, (London, i828), vol. ii, p. 359.

2 Parliamentary Papers, (1823), vol. xix, pp. I4 et seq., Montmorency. to Wellington, 26 December, 1822.

Stapleton, Life of Canning, vol. i, p. 226; Walpole (S.), History of England, (London, 1890), vol. iii, p. 50.

-Wellington, Despatches, vol. i, p. 519; British and Foreign State Papers, vol. x, p. 9; Parliamentary Papers, vol. xix, pp. 6-7; F. O., Continent, Verona, November, I822, Wellington, Memorandum, Is November, 1822, no. 22.

- Stapleton, Life of Canring, vol. i, pp. 226 et seq. 
those sent by the other Allies. ${ }^{1} \quad$ Moreover, the French despatch arrived in Madrid two days earlier than those of the other powers, and the French Minister at Madrid took advantage of its earlier arrival to "interpret" it to the Spanish government ${ }^{2}$ and while the rest of the Allies recalled their Ministers from Madrid, France did not do so immediately. ${ }^{3}$

It seemed clear, therefore, that France was taking advantage of the policy of intervention which had been laid down by the Alliance, and to which its members gave support, to create for herself favorable relations with Spain." ${ }^{4}$ Thus the policy of intervention in Spain for the purpose of restoring Ferdinand VII to his throne was indirectly to serve the interests of France. ${ }^{5}$ The French government was undoubtedly actuated, despite its constitutional form, by a desire to enforce the principle of legitimacy in the neighboring state, since Louis XVIII himself owed his restoration to that principle. ${ }^{8}$ But France had lost prestige, power and territory as a result of Napoleon's defeat, and the thought of recovering from these losses influenced the attitude of French statesmen and caused France to incline toward independent action in dealing with Spain. ${ }^{7}$ By assuming a

1 Stapleton, Life of Canning, vol. i, pp. 226 et seq.; British and Foreign State Papers, vol. x, p. 38, William à Court to Canning, 7 January, 1823 .

- British and Foreign State Papers, vol. x, p. 38, William à Court to Canning, 7 January, 1823; Stapleton, Life of Canning, vol. i, pp. 266 et seq.

2 Phillips, op. cit., p. 280.

- Stapleton, Life of Canning, vol. i, p. 226.

- F. O., France, January-April, 1823, Canning to Stuart, 25 February, 1823, no. 20.

- Stapleton, Life of Canning, vol. i, pp. 223-224.

'Stapleton, George Canning and His Times, pp. 369 et seq., Canning to Bagot, 3 January, 1823: Phillips, op. cit., p. 280. 
conciliatory attitude France possibly expected to gain commercial advantages in trade with the Spanish colonial empire or actually to acquire possession of part of that empire. ${ }^{2}$ If such were the motives of the French government it could ill afford to accept Canning's offer of mediation; ${ }^{2}$ for, if England had been successful in preventing war between the two countries, then English influence at Madrid would have increased to the detriment of French ambitions. Of such consequences France was keenly suspicious. ${ }^{3}$ It was also Canning's thought that British mediation would create between England and Spain a friendly feeling that would be more efficacious than a display of force in the settlement of the difficulties existing between these two countries. ${ }^{4}$ Out of a group of circumstances such as these the ambitious plans of the Congress of Verona were reduced to a rivalry between England and France for diplomatic ascendancy at the Spanish court, not as the ultimate aim, but as a step toward commercial advantage. ${ }^{5}$ England was no less anxious to maintain the influence which she had established at Madrid during the Peninsular War than was France to establish hers. ${ }^{\circ}$

However, the opportunity was not lacking for the substitution of Anglo-French cooperation for a state of rivalry. While the commercial classes of France advocated the re-

1 Stapleton, Life of Canning, vol. i, p. 226; Phillips, op. cit., 264.

$2 F$. O., Continent, Verona, September-December, 1822, Canning to Wellington, I3 December, I822, no. 28, note; British and Foreign State Papers, vol. x, p. 28, Canning to William à Court, 9 .December, 1822; Stapleton, Life of Canning, vol. i, pp. 223-224.

-F. O., France, March, 1823, Stuart to Canning, 3 March, 1823.

4 Ibid., Continent, Verona, September-December, 18z2, Canning to Wellington, 6 December, 1822, no. 24.

- Ibid., Canning to Wellington, 17 December, 18c2, no. 29.

- Phillips, op. cit., p. 260. 
cognition of South American independence in the interest of French commerce, ${ }^{2}$ the more conservative legitimists would shape the Spanish-American policy of France in harmony with the wishes of Spain. ${ }^{2}$ It was for the French government to choose whether to support the cause of colonial independence in response to commercial interest, or to pursue a policy in harmony with the Doctrine of Intervention in support of legitimacy. ${ }^{3}$ Had it chosen to favor colonial independence, an Anglo-French understanding relative to South America would not have been impossible. But the French government preferred cooperation with the allied powers in the solution of the Spanish-American question." The allied policy would take the form either of reconquest of the former Spanish-American colonies or an effort to establish in Spanish America independent Bourbon monarchies. ${ }^{5}$ With the exception of the Spanish royalists, few men seriously believed in the possibility of reconquest, while it seemed to the French government that the establishment of independent Bourbon monarchies in Spanish America would at the same time satisfy the principle of legitimacy and the interests of the commercial classes. ${ }^{\circ}$ The success of such a policy would depend, on the one hand, upon the extent of French influence at Madrid, and on the other, upon the attitude of England.

1 Paris, Arch. des Aff. Etr., Mém. et Docs., vol. xxxv, f. I6r ; Villèle (Joachim de), Mémoires, (Paris, I888-I8so), vol. iii, pp. 7o et seq; Perkins (Dexter), "Europe, Spanish America, and the Monroe Doctrine," Am. Hist. Rev., vol. xxvii, p. 208.

Ibid.

I lbid., pp. 208-209.

4 Ibid., p. 209 ; Chateaubriand, Congress of Verona, (London, 1838), vol. i, pp. IOI-102.

s Paris, Corr. Pol., Espagne, vol. 716, f. 27 ; vol. 722, f. 56 ; Villèle, op. cit., vol. iv, pp. 200-20I ; Perkins, Am. Hist. Rev., vol. xxvii, p. 2 ro.

-1bid; Chateaubriand, op. cit., vol. i, p. IO2; vol. ii, p. 209. 
Scarcely had the Congress of Verona come to its close, then, when its scheme for the maintenance of the political status quo yielded to the forces of international rivalry. Canning made a significant comment on the situation as it appeared to him in the early part of 1823 :

.... the issue of Verona .... has split the one and indivisible Alliance into three parts as distinct as the constitutions of England, France, and Muscovy. First there are the three absolute Crowns, who send their angry despatches to their Ministers at Madrid with orders to come away if they do not receive submissive answers in fifteen days. Next, there is France. who sends a whining despatch to her Minister, with no orders at all as to coming away. Thirdly, there is we, who are in a course of amicable and furious correspondence with Spain; amicable so far as relates to Europe, in which quarter of the globe we defend her against invasion; furious in relation to America, where we have a squadron now employed in seeking forcible redress for grievances.... Every nation for itself, and God for all. Only bid your Emperor be quiet, for the time of Areopagus, and the like of that, is gone by. ${ }^{1}$

Whatever doubts concerning her motives France may have produced by rejecting the British offers of mediation, they were dispelled by the speech of Louis XVIII on 28 January, I823. In that speech, which the king delivered in the chamber, he virtually declared war on Spain:

I have ordered the recall of my Minister. One hundred thousand Frenchmen, commanded by a prince of my family, by him whom my heart delights to call my son, are ready to march, invoking the God of St. Louis to preserve the throne of Spain for the descendant of Henry IV, to save this beauti-

'Stapleton, George Canning and His Times, pp. 369-370, Canning to Bagot, 3 January, 1823. 
ful kingdom from its ruin, and to reconcile it with Europe. If war is inevitable, I will use my utmost efforts to confine its area and to limit its duration. It shall only be undertaken to conquer the peace which the state of Spain would make impossible. Let Ferdinand VII be free to give to his people the institutions which they cannot hold except from him. ${ }^{1}$

Here, at last, the French monarch announced the policy of his government. Unsuccessful in their efforts to influence the Constitutionalists and unwilling to accept mediation," the French would use force to restore Ferdinand to the throne of his fathers untrammeled by the limitations which the constitution had placed upon his power. Moreover, if the institutions of Spain were to be changed, such changes must proceed from royal initiative, not from that of the people. In that respect the king's speech bore a striking resemblance to the declaration of the Congress of Laibach in which the continental monarchs agreed that "useful or necessary changes in legislation and in the administration of states ought only to emanate from the free-will and the intelligent and well-weighed conviction of those whom God had rendered responsible for power." ${ }^{3}$ Harmony' certainly prevailed between France and her allies. But Castlereagh had lost no time in protesting against the Troppau Protocol, 4 and Canning was just as emphatic in voicing British opposition to French invasion of Spain. Canning declared that that part of the King's speech in which it was claimed that the only legitimate constitution is that which

1 British and Foreign State Papers, vol. x. p. 758; F. O., France, January, 1823, Stuart to Canning, 28 January, 1823, no. 26; cf. ibid., Continent, Verona, November and December, I822, Wellington to Canning, 16 December, 1822 , no. 56 .

- Stapleton, Life of Canning, vol. i, pp. 247-248.

3 British and Foreign State Papers, vol. viii, pp. 1201 et seq.

- Hertslet, op. cit., vol. i, pp. 664-665. 
emanates from the sovereign," struck at the very roots of the British Constitution." I In taking the attitude of opposition to the policy announced by the king of France, Canning had the united support of the British people: "Perhaps there never was an occasion in which the opinions of the people of this country were so united as they were in their condemnation and abhorrence of this document; ... the Whigs and Tories were all as one man, of the same way of thinking, from one end of the country to the other." 2 "The people of Great Britain realized that their influence in Spain was to be supplanted by that of France; and along with the loss of foreign influence, British liberals saw the destruction of constitutional government, the merchant class saw a danger to British commerce, and British patriots the uselessness of their military exploits in the Peninsular War. ${ }^{3}$ This unanimity of British public opinion must have afforded the British Ministry a great deal of satisfaction. Moreover, it would be a source of great strength in support of Canning's subsequent policy when, in case of French success in Spain, he should determine to thwart the designs of France in Spanish America.

Some days before the King's speech in the Chamber, Chateaubriand, who had succeeded Montmorency as Minister of Foreign Affairs, had tried to convince Canning of the difficult position of France as a neighbor of Spain. The geographical nearness of the two countries made it especially necessary for France to take proper precaution lest the disorder in Spain should spread into France. ${ }^{1}$ However, he

Stapleton, Life of Canning, vol. i, p. 339.

'Stapleton, Life of Canning, vol. i, p. 251.

Walpole, op. cit., vol. iii, p. 53.

- Parliamentary Papers, (1823), vol. xix, p. 20 , Chateaubriand to Canning, 23 January, 1823. 
admitted that if the Spanish constitution could be so changed as to eliminate the provisions guaranteeing popular sovereignty, and if the change could be shown to have emanated from the king, "neither France nor any other Power will have the right to complain." ' But the king's speech had so irritated the Spanish people as to render such modification impossible. ${ }^{2}$ It was evident that the French statesman was preparing for war with Spain. The king's speech confirmed that belief.

However, Canning did not cease in his efforts to maintain peace between France and Spain. ${ }^{3}$ If successful in these efforts, he would: (a) establish a constitutional government in Spain; (b) thwart the Alliance in its policy of intervention in Spain; (c) prevent the aggrandizement of France at the expense of Spain; (d) safeguard British commerce. With these aims in mind he tried to point out to Monsieur of France, brother of Louis XVIII and later himself king of France as Charles $\mathrm{X}$, the great dangers involved in a war with Spain. Such a war would likely rekindle the smoldering embers that still remained from the conflagration of the Napoleonic period. It would start a new war of " extreme principles" that would overthrow the whole European settlement. ${ }^{4}$ It would be a source of great danger to France to intervene in behalf of Ferdinand, because not only would the Spanish people constitute a most formidable obstacle, but France might also incur the hostility of the British people owing to the conflict of principles involved, while any prospect of permanent

1 F. O., France, January, 1823, Stuart to Canning, 27 January, 1823.

2 Ibid., February, 1823, Stuart to Canning, 17 February, 1823, no. 55.

3 Ibid., January-April, 1823, Canning to Stuart, 4 February, I823, no. 11.

- Stapleton, Some Correspondence of George Canning, (London, 1887), vol. i, p. 72, Canning to Monsieur, I February, 1823. 
occupation of Spain by France would suggest to England "considerations of the gravest nature." 1 As for the principles of government, said Canning, "If I were called upon to choose between the principle laid down in the speech of H. M. the King of France, and its antagonist principle the sovereignty of the people, I should feel myself compelled to acknowledge that the former is the more alien to the British Constitution." ' Not only could not the British Ministry enter into a compact with France in a war against Spain, but not even was France to expect any moral support from Britain, because the British people were in sympathy with the very cause in opposition to which France invaded Spain. ${ }^{3}$ In this way Canning cleverly capitalized the democratic sentiment in Great Britain in the interest of peace.

In order to remove all cause for suspicion regarding the motives of his persistent efforts for peace, Canning made it plain to Monsieur that Great Britain had no desire for territory:

We want no more .... neither islands, nor provinces, nor privileges of trade. Trade . . . but not exclusive privileges .... all the advantages and all the islands that Spain could offer us, are nothing worth in our eyes compared with the continuance of peace. It is of that alone that we are avaricious, however little the French Ministers may believe us. ${ }^{*}$

Villèle was in favor of peace with Spain, ${ }^{5}$ but his efforts

${ }^{1} F$. O., France, January-April, I823, Canning to Stuart, 4 February, 1823, no. 15.

${ }^{2}$ Stapleton, Some Correspondence of George Canning, vol. i, p. 74, Canning to Monsieur, I February, 1823.

s Ibid.

4 lbid., pp. 75-76.

- F. O., France, January, 1823, Stuart to Canning, 23 January, 1823, no. 21. 
availed nothing in the face of the war party in the French government. He remained premier of France, and for the sake of apparent consistency in his position he blamed the zeal of the Tsar for the step that France was about to take: in case that France did not attack Spain, the Tsar would march a Russian army through France into Spain. Such a movement might be a source of much trouble for France, and hence Villèle's statement that "it was necessary to attack the South in order to escape the North." 1

Unlike the French Republicans during the revolutionary period, the Constitutionalists of Spain had cautiously avoided committing any act that might give offence to the governments of neighboring states, and thus furnish them with a cause for war. ${ }^{2}$ So far as France, then, was acting in defence of her own existing institutions and those of her allies, she was striking at dangers rather imaginary than real. There is room for suspecting that she was employing the situation in Spain as a convenient pretext for advancing both her political influence and her economic interests. The circumstances which Chateaubriand detailed in justification of war with Spain pointed to the presence of commercial motives: piratical attacks upon French commerce in the American seas, ${ }^{3}$ necessitating naval operations for its protection; decreased consumption of French goods in Spain, due to the disturbed conditions of internal affairs; ${ }^{4}$ French consuls threatened in Spanish ports ${ }^{5}$ and the necessity of keeping armed forces on the Spanish frontier, made the

'Stapleton, Life of Canning, vol. i, p. 262.

2 lbid., p. 272.

Ibid., p. 274.

Ibid., p. 275.

slbid., p. 276.

- Stapleton, Life of Canring, vol. i, pp. 276-277. 
more necessary by the geographical situation of France., That France expected to derive great advantages from a war with Spain is evidenced by the opposition of the French government to any interference in the question by the other members of the Alliance, and by its resolution "to resist by every possible means their participation in the contest." ${ }^{2}$

A most critical situation was growing out of the determination of France to intervene in Spain. Whether the approaching war was to be limited to a contest between France and the Spanish Constitutionalists or to grow into a general European struggle on a large scale, depended upon the policy of the British government. Great Britain had opposed the policy of intervention in the Congresses because she claimed it was based on an unwarranted interpretation of the treaties of 1815 , and she had broken with the Alliance for the same reason at the Congress of Verona. Moreover, after the Alliance had defied the opposition of Great Britain and commissioned France to suppress the Spanish Constitutionalists, Canning continued to use all the influence of his position to prevent a Franco-Spanish war, first by offering mediation, then by explaining to France the dangers of such a war. When it became apparent that Canning's efforts for peace were unavailing, the question immediately arose, What stand would Great Britain take? Would she carry her opposition to the policy of intervention a step farther and enter the conflict on the side of the Constitutionalists? Having broken with her allies, would Great Britain now: employ her armed forces against them? The opinion prevailed rather generally in Spain that not only would England not be a party to intervention, but that the English

1 Parliamentary Papers, (1823), vol. xix, p. 20, Chateaubriand to Canning, 23 January, 1823.

'F. O., France, January, I823, Stuart to Canning, 27 January, 1823, no. 24 ; ibid., Stuart to Canning, 30 January, 1823. 
government would throw down the gauntlet against any power which would attempt such intervention. ${ }^{1}$

British opinion was divided as to what course England should take. Canning and the Ministry favored neutrality. ${ }^{2}$ Of such a policy two men, Lord Grey and Mr. Hobhouse, were the most outspoken opponents. They threw the weight of their influence strongly on the side of British intervention in behalf of the Constitutionalists. France, said Lord Grey, committed an injustice by interfering with the sovereign rights of an independent state; ${ }^{3}$ occupation of Spain by France would disturb the balance of power to the detriment of Great Britain; ${ }^{4}$ and if Portugal were attacked by France, Great Britain would, after all, by virtue of a treaty with Portugal, have to throw the weight of her power eventually against France. ${ }^{5}$

While motives of justice and consistency favored British intervention, motives of policy and peace made a position of neutrality the more expedient. Many circumstances compelled such a course. Even if France were successful in her invasion of Spain, England would have no fear for her own liberty. ${ }^{\circ}$ Her insular position and her naval power were sufficient guarantees against immediate dangers. There was no longer any real fear of a union of Spain and France, because an Anglo-Spanish treaty of I8I4 bound

1 F. O., Spain, September-December, 1822, Canning to William à Court, 28 December, I822, no. 40.

2 bid., William à Court to Canning, 27 October, I822, no. 21 .

3 British and Foreign State Papers, vol. x, p. 48, Canning to William à Court, 26 January, I823; Parliamentary Papers, (1823), vol. xix, pp. 33 et seq., Canning to William à Court, II January, I823.

4 Stapleton, Life of Canning, vol. i, pp. 3I7, 354.

5 Ibid., p. 318; F. O., France, January-April, I823, Canning to Stuart, 3I March, I823, no. 29.

- Stapleton, Life of Canning, vol. i, p. 321 . 
Spain not to enter into any engagement with France that would renew the Family Compact, ${ }^{1}$ affect the independence of Spain, or make any treaty with France that would be injurious to His Britannic Majesty; and Chateaubriand declared that the stipulations of the treaty would be observed. ${ }^{2}$ Even though a union of France and Spain should be effected, it would never be the source of danger to British interests in the nineteenth century that it might have been in the days of Spain's greatness. ${ }^{3}$ Spain, instead of being a source of strength to France, would be a burden. ${ }^{4}$ Though France might gain possession of Spain, such an extension of her power could easily be balanced by the recognition of the Spanish-American colonies by Great Britain. ${ }^{5}$ So long, then, as France confined her operations to Spain, refrained from permanent military occupation and from effecting changes in the relations of Spain with other powers, England's interests were in no immediate danger. ${ }^{6}$

Participation on the side of the Constitutionalists, offered greater risks than did the policy of neutrality. If Great Britain had entered the war against France, the latter would unquestionably have gained the military support of her continental allies, ${ }^{7}$ while Great Britain would have fought practically alone against a coalition of powers, which, in a land war for which Great Britain was not so well fitted,

1 British and Foreign States Papers, vol. x, p. 76.

${ }^{2} F$. O., Spain, I8I4, Treaty of Alliance and Friendship, 5 July, I814; Stapleton, Life of Canning, vol. i, pp. 313-3I4.

3 Ibid., p. 323.

4 Ibid., p. 325 .

Ibid., pp. 325-326; vol. ii, p. 2.

- F. O., France, January-April, I823, Canning to Stuart, 3I March, 1823 .

'7 Stapleton, Life of Canning, vol. i, p. 327; ibid., Correspondence of George Canning, vol. i, p. 86. 
might have proved themselves the victors. ${ }^{1}$ Great Britain had been at war for almost a century, and had now turned her energy and resources to peaceful pursuits. She could little afford to interrupt the process of reconstruction to engage in a war, not yet absolutely necessary for her own safety and which might spread, if she did enter, into a European conflagration with most disastrous consequences. ${ }^{2}$ Indeed, had Great Britain opposed France in her invasion of Spain, the French government could easily have converted the war into a war against Great Britain, and in that way made it more popular at home. ${ }^{3}$ Moreover, the FrancoSpanish war, so far as it was the outgrowth of the policy of intervention, was a conflict between two political systems. Canning would identify the policy of his country with neither extreme. ${ }^{4}$ He shrank from making conservatism $v$. liberalism the issue of any conflict of arms. Nor had his opposition to the French invasion of Spain been prompted by any particular sympathy with liberal institutions; it was prompted rather by his opposition to the policy of intervention irrespective of the form of government.

The national interests of Great Britain, then, demanded a policy of neutrality. But it was to have its limits. Refusing to identify British policy with the cause of liberalism, fearing no union of France and Spain, ${ }^{5}$ and feeling confident that Austria, Prussia and Russia would prevent France from

${ }^{1}$ Stapleton, Correspondence of George Canning, vol. i, p. 86.

3 F. O., Spain, September-December, 1822, Canning to William à 'Court, I7 December, I822; Stapleton, Life of Canning, vol. i, p. 327 ; The Morning Post, 8 February, I823.

'Stapleton, Correspondence of George Canning, vol. i, pp. 85-86, Memorandum, February, I823.

- Ibid., p .74.

${ }^{5}$ Stapleton, Life of, Canning, vol. i, pp. 313-314. 
overthrowing the balance of power, ${ }^{1}$ Canning had only one contingency to fear in the event that the French were successful in Spain, and that was the extension of their power and influence to Spanish America. ${ }^{2}$ An attempt by France, or any of her allies, singly or in combination, to carry the policy of intervention to Spanish America would interfere with British commerce and would be opposed. In a memorandum of his policy drawn up by Canning in February, I 823, he outlined his reasons for neutrality in the approaching war between France and Spain, and very definitely and with emphasis recorded his determination to prevent any intervention in Spanish America:

Here, however, forbearance should stop. We have the means of easily and effectually preventing any such projects on the part of Spain and France as those to which I have referred respecting South America being carried into execution. There our naval superiority would tell. ${ }^{3}$

There a maritime war would be to a purpose; I should have no difficulty in deciding that we ought to prevent, by every means in our power, perhaps Spain from sending ai single regiment to South America after the supposed termination of the war with Spain, but certainly France from affording to Spain any aid or assistance for this purpose. ${ }^{4}$

Somewhat later, 3I March, I823, Canning reiterated in a despatch to Sir Charles Stuart, British Minister at Paris, his determination to prevent France from acquiring possession of any part of the Spanish colonies either by conquest

${ }_{1}^{1}$ Stapleton, Life of Canning, vol. i, p. 462; George Canning and His Times, pp. 376-377.

- Canning, Speeches, vol. v, p. 27.

- The italics are mine.

4 Stapleton, Correspondence of George Canning, vol. i, pp. 88-89, Memorandum, February, I823; infra, p. I37. 
or by cession from Spain. ${ }^{1}$ He even referred in the same despatch to the recognition of the independent status of those colonies as a matter subject to " various external circumstances, as well as by the more or less satisfactory progress, in each state, towards a regular and settled form of Government." 2 The failure of the French government to reply to this despatch was considered in England as tacit acquiescence without, however, affording absolute assurance.

British neutrality, accordingly, was to be limited to the European phase of the impending conflict. ${ }^{3}$ Should it assume an American phase, new issues - commercial advantage and imperialism - would appear so prominently as to overshadow the political issue of its European phase. These new issues would make it not only more possible, but desirable and necessary, for Great Britain to enter the war in opposition to France, because the relation of these issues to the vital interests of Great Britain was far more immediate than was the political issue of liberalism $v$. conservatism in Spain, or the policy of intervention in European states, so long as the balance of power was maintained.

The decision of the British government to pursue a policy of neutrality in the Franco-Spanish war was based very largely upon the fact of its being a land war." ${ }^{4}$ But should the war be extended into South America, Great Britain could enter it on the side of the Spanish colonies to greater advantage. The war would then become a maritime war, and the full strength of the British navy could be employed

1 Stapleton, Life of Canning, vol. ii, pp. I8-19.

${ }^{2}$ F. O., France, January-April, I823, Canning to Stuart, 3I March, I823, no. 29; Hansard, Parl. Debates, (n. s.), vol. viii, p. 89I ; Stapleton, Life of Canning, vol. ii, pp. I8 et seq.

- The Morning Post, I6 April, I823.

4 Stapleton, Correspondence of George Canning, vol. i, p. 86, Memorandum, February, I823. 
against France and her allies, should they participate actively. - Canning realized fully the naval superiority of his country, and determined to use it, should France attempt to interfere in South America. ${ }^{1}$

It so happened that Great Britain was weak where France was strong and strong where France was weak. The latter, knowing British naval power, was not likely alone to attack the nascent states of South America so long as such an attack would surely invite the armed opposition of Great Britain. ${ }^{2}$ Therefore, whatever advantages Great Britain saw for herself in the independence of the Spanish-American colonies could be gained rather through a policy of neutrality in the Franco-Spanish war than by active participation with doubtful chances of success.

A most powerful consideration with Canning in his determination not to remain neutral should France, singly or together with her allies, attack Spanish America, was undoubtedly his knowledge of the Latin-American policy of the United States. The interest which this country had for a long time manifested in the South American independence movement, the expressed desire of the United States in 1818 for Anglo-American cooperation, ${ }^{3}$ the contempt of the United States for the reactionary political system of Europe, and the fact that the government of the United States had in 1822 extended recognition to the new states of South America constituted sufficient indication of the attitude of the United States towards European intervention in South America. Canning must thereby have been convinced of the readiness of this country to cooperate

1 Stapleton, Correspondence of George Canning, vol. i, p. 86.

Stapleton, Life of Canning, vol. i, p. 389.

3 Castlereagh, Correspondence, vol. xi, p. 458, Bagot's Report of Interviews with Adams. 
with Great Britain against such interference. Although still withholding recognition of the new South American states, Canning in a memorandum of $1_{5}$ November, 1822 , commended the action of the United States government in extending recognition to them:

It is not intended to hold out the example of the United States as recommending a decision to which their very origin must necessarily have inclined them with so strong a bias; but it can hardly be denied that the United State government .... pursues upon the whole a more straightforward course, and presents itself before the world in a more intelligible position, than Great Britain forbearing for the sake of Spain to acknowledge the separate existence of her colonies. ${ }^{1}$

While the British government pursued a neutral policy in the Franco-Spanish war, the press and the public voiced their indignation against the invasion of Spain; and had Canning decided in favor of defending the Constitutionalists of Spain, he would certainly have had the support of the English nation. The London Times commented significantly on the policy of the Alliance as being contradictory| of human rights: "Those three or four unhappy men who have separated themselves from the rest of the species, and call themselves 'Holy', employ every day some new engine of their 'policy' against those rights which a wiser policy would teach them that it is their first interest to foster." ${ }_{2}$ Like the Times, the Examiner considered the principles of the Alliance as "incompatible with the existence of freedom in any portion of Europe." ${ }^{3}$ The conclusion to which a study of Canning's opposition to the French invasion of

Stapleton, Correspondence of George Canning, vol. i, p. 5I.

2 The London Times, 8 February, 1823.

- The Examiner, 9 November, 1823. 
Spain inevitably leads is that he based that opposition upon his policy of non-intervention in the internal affairs of an independent state. The press, on the other hand, emphasized the anti-liberal character of the policy of the Alliance. Instance the liberal tone of the following editorial note:

The effect produced on all classes in this country by the meditated and wanton attack on the liberties of Spain and Portugal, is worthy of the nation, and we are glad to find that the discussions at the opening of the Parliament, on this interesting subject, have, if possible, heightened that indignation which already glowed in the hearts of our country-men. ${ }^{1}$

The Examiner thought that Canning had not gone sufficiently far in his protest against the policy of the Alliance, and was severely critical of his failure to aid the liberal cause in Spain. It deplored the fact that while Spain was being: conquered, England looked on "in silence and inaction." ${ }_{2}$ While in 1808 England had employed her armies and fleets at great expense " to rescue Spain from the grasp of France, in 1823 England stirs not a finger, nor utters a syllable to save Spain from conquest by French armies." ${ }^{3}$ The liberalism of Canning had become "cramped and offcialized." 4

The people of Great Britain not only sympathized with the cause of Spanish liberty, but they actively aided that cause by means of popular subscriptions ${ }^{5}$ and public meetings. ${ }^{\circ}$ On 4 June, I823, a group of about fifty representa-

1 The Morning Chronicle, Io February, 1823.

The Examiner, 9 November, 1823.

I Ibid.

Ibid., 4 January, I824.

- The Morning Chronicle, 28 May, I823; F. O., France, May-December, I823, Canning to Stuart, 8 July, I823, no. 54 .

- The Morning Chronicle, 3 June, I823. 
tive citizens petitioned the Lord Mayor of London to convene a court of the Common Council for the purpose of considering the practicability of making a contribution out of the city funds for the cause of Spanish independence. The purpose of this contribution was to "assist them to triumph effectually over the unprincipled invasion of their country by the ambitious and wicked Bourbon Government of France; which invasion not only militates against the principles of the British Constitution, but the very existence of Civil Society." ${ }^{1}$ A public subscription was opened on I3 June, 1823. At the same time the Bourbons tried to raise money in England, but the unpopularity of their "wicked designs" was evidenced by the failure of their attempt. ${ }^{2}$ The Alliance was becoming the object not only of the criticism of serious-minded statesmen ${ }^{3}$ and journalists, but likewise of the ridicule of poetic wit, instanced by the following "Hymn to the Holy Alliance":

"Hurrah! Hurrah! for the Kings of the earth, Let us worship the Holy Alliance,

For the Royal Millennium will shortly have birth, And the Monarchs may hurl a defiance

To Liberals, Patriots, Sages, and all

Who would Tyrants control, and the world disenthrall." 4

Although the British people would readily have gone to war in defense of Spanish liberty, the wisdom of the government's policy was soon confirmed. ${ }^{5}$ Only a minority of the Spanish people favored the constitution, ${ }^{6}$ while a large num-

The Morning Chronicle, 6 June, I823.

I Ibid., 5 July, I823.

3 Hansard, Parl. Debates, (n. s.), vol. viii, p. 774.

- The Morning Chronicle, 7 November, 1823 .

${ }^{5}$ Stapleton, Life of Canning, vol. i, pp. 460-46r.

- Ibid. 
ber of Spaniards actually welcomed the French invaders, and the bulk of the nation were indifferent to the issue of the struggle. ${ }^{2} \quad$ Under such circumstances France had every chance of success. On I November, I823, the war ended by the surrender of Barcelona to the Royalists. France was victorious. Ferdinand was restored by her aid. England was an interested observer, but ready and determined to prevent the French from gaining any part of Spanish America, or from making any attempt to restore the loyalty of the Spanish colonies to Ferdinand VII, under cover of the doctrine of intervention.

1 F. O., France, April, I823, Stuart to Canning, in April, I823, no. I44; Chapman (C. E.), A History of Spain, (New York, 1918), p. 497.

${ }^{2} F$. O., Spain, September-December, I822, William à Court to Canning, 7 October, 1822, no. 1o. 


\section{CHAPTER IV}

\section{British Interests in South Ámerica}

IN a letter, dated 3 I March, I823, to Sir Charles Stuart, British ambassador at Paris, Canning had declared it as his opinion that "time and the course of events appear to have substantially decided their [the Spanish colonies in America] separation from the mother country," disclaiming any intention to appropriate "the smallest portion of the late Spanish possessions in America," and that he was satisfied that France would not seek to acquire any part of them "either by conquest, or by cession, from Spain." " The statement contains the announcement of British policy from which one necessarily concludes that, in the event of French success in Spain, France must neither carry the principles of the Alliance beyond the Atlantic by force of arms, nor seek compensation for her efforts by sharing with Spain the latter's American empire. What were the principles, the aims or the motives upon which that policy was based? In the answer to this question we may expect to find the chief reasons for Britain's interest in South 'America, for her opposition to the extension of French influence thither, and for Canning's desire for a joint AngloAmerican declaration as a "counterblast" to the machinations and designs of the Alliance.

Among the great states of Europe Great Britain was politically the most liberal. The revolutionary origin of

1 Parliamentary Papers, (1823), vol. xix, pp. 59-60, Canning to Stuart, 3I March, 1823; F. O., France, January $\lrcorner$ April, I823. 
her constitution and the fact of parliamentary supremacy might suggest the possibility of a sympathetic attitude toward movements of political reform everywhere.

Great Britain had definitely taken her stand in opposition to the doctrine of intervention, both because her government deemed that policy contrary to the treaties of I8I5, and because its pursuit involved undue interference with the internal affairs of an independent country. To be consistent in her attitude toward that policy as well as true to her own view of the status of the Spanish-American colonies as expressed in Canning's letter to Stuart ( $3^{\prime}$ March, I823), Great Britain must oppose any attempt of the Alliance to intervene in South America.

Great Britain was the home of the Industrial Revolution. There it had reached a higher development than anywhere else. Britain's insular position made her a maritime state. Her economic interests were, therefore, primarily commercial. ${ }^{1}$ During the eighteenth century British manufactures had depended largely on the continental market; but conditions resulting from the Napoleonic wars caused a partial loss of that market for English goods. ${ }^{2}$ The continental nations were suffering from the decline of their purchasing power through impoverishment. ${ }^{3}$ They also were endeavoring to build up their own industries by means of protective tariffs. ${ }^{4}$ Conditions had changed considerably; within a period of fifteen years. As a result of the Peace of Amiens, March, 1802 , the total value of British exports to the continental states increased from $\mathfrak{f}_{17,367,218}$ in

1 Mahan, op. cit., p. 28.

${ }^{2}$ Levi (L.), History of British Commerce, (London, I880), p. I49.

${ }^{3}$ Ibid.; Cunningham (W.), The Growth of English Industry and Commerce in Modern Times, (Cambridge, 1892), p. 591.

4 Ibid.; Levi, op. cit., p. 152. 
I80I to $£ 22,061,356$ in $1802,{ }^{1}$ which was somewhat in proportion to the rate of increase of the total British exports to all the markets of the world within the same period, from

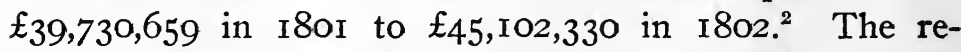
sumption of war in 1803 caused a decline of British exports to the continent, while the colonial trade increased. ${ }^{3}$ When finally Napoleon had been defeated, and peace had again been declared, England failed to recover the continental market as quickly as in 1802 , for reasons already stated. ${ }^{4}$ In $18 I_{4}$ her exports to the continental market amounted to $\mathfrak{f}_{32}, 6 \mathrm{I} 7,289$; but in I8I9 they had declined to $\mathfrak{f}_{23}$, OI 3 ,226 and reached a total of only $£ 24,995,268$ in 1822.5 The total British exports were similarly affected: $\mathfrak{f}_{45}, 494$,219 in $1814 ; \mathfrak{f}_{35,208,32 \mathrm{I}}$ in 1819 ; and $\mathfrak{f}_{3} 6,968,964$ in $1822 .^{6}$

Meanwhile British goods were similarly affected in the markets of the United States. The amount of British imports into the United States actually increased after the War of Independence, ${ }^{\top}$ and about one-third of the total British exports during the three years of $1805-1807$ were to the United States. ${ }^{8}$ As the result of Orders in Council, and of the Embargo and Non-Intercourse Acts, the greater part of this trade was lost. The American tendency toward

1 Marshall, op. cit., pt. iii, pp. 7I-75.

2 Porter (G. R.), The Progress of the Nation, (London, 1838), vol. ii, p. 98.

3 Marshall, op. cit., pt. iii, pp. 74-75.

4 Supra, p. 77.

5 Marshall, op. cit., pt. iii, pp. 7I-75.

6 Porter, op. cit., p. 98.

${ }^{7}$ Cunningham, op. cit., p. 512; Marshall, op. cit., pt. iii, pp. 7I-75.

8 Cunningham, op. cit., p. 519; Porter, op. cit., vol. ii, p. 145; Bogart, (E. L.), The Economic History of the United States, (New York, I913), p. 156. 
economic independence, fostered by the War of I8I2, inaugurated a period of rapid industrial development which was destined to make this country less dependent upon British manufactures. When, therefore, at the close of the War of I8I2, Great Britain threatened to prevent the successful development of our industries by flooding the American market with British goods, economic interest, combined with patriotism, influenced Congress to pass the protective tariff of I8I6. The effect was immediate upon the volume of British exports to this country. They dropped from

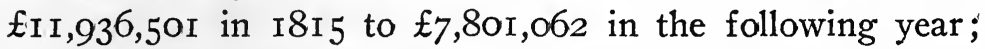
and to $£_{3,920,262}$ in $1820,{ }^{1}$ for which the crisis of 1819 was partly responsible. ${ }^{2}$

It was thus that a combination of circumstances, some the effects of war, others due to the deliberate efforts of nations to develop their own resources in order to render themselves economically more independent, reacted against the British export trade for at least a decade following the close of the Napoleonic wars. The average annual value of British exports for the ten years I8II-I820 hardly exceeded that of the period I8OI-I8IO. ${ }^{3}$

This decline of the export trade was felt the more severely in England because of her improved methods of production, resulting in the accumulation of large stocks." Loss of markets compelled the manufacturers to reduce production, resulting in unemployment and low wages ${ }^{5}$ especially in the textile industry. ${ }^{6}$ England now felt the

1 Marshall, op. cit., pt. iii, p. 74.

2 Dewey (D. R.), Financial History of the United States, (New York, 1903), p. 166; Bogart, op. cit., p. 239.

- Porter, op. cit., vol. ii, p. Ioo; Levi, op. cit., p. I5I.

- Cunningham, op. cit., p. 508.

- Levi, op. cit., p. I49.

- Porter, op. cit., vol. ii, pp. 252-253. 
need of adopting a policy of greater freedom of trade; ${ }^{1}$ and the relaxation of the navigation laws in $1822^{2}$ promoted commerce with Latin America. ${ }^{3}$

The growth of the South American market would compensate in a large measure for the loss of the markets elsewhere. Indeed, the motives which had determined British policy relative to Spanish America ever since I702 had been chiefly those of trade. ${ }^{4}$ In I823 her chief interest in South America was still commercial, ${ }^{5}$ only far greater than it had ever been before, because of the decline of the continental market in Europe and the development of favorable trade relations with Latin America during the war period. It was in order to continue these favorable trade relations that the British government was led to resist allied intervention in the former American colonies of Spain. ${ }^{6}$ It was the thought of the commercial interests of his country in Latin America which caused Canning to say in a letter to Wellington that " in the present state of the world, of the peninsula, of the country, the American questions are out of all proportion more important than the European, and if we do not seize and turn them to our advantage in time we shall rue the loss of an opportunity never to be recovered." ?

The period of the Napoleonic wars and the succeeding

1 Page (W.), Commerce and Industry, (London, 1919), pp. 19 et seq.

2 Levi, op. cit., pp. I60, 166.

- Page, op. cit., pp. 53 et seq; Hansard, Parl. Debates, (n. s.), vol. xiv, p. 773 ; ibid., p. 69.

${ }^{4}$ Camb. Mod. Hist., vol. x, p. 308.

- Parliamentary Papers, (I882), vol. 1xxx, p. 88, Frelinghuysen to Lowell, 8 May, I882; Redidaway, op. cit., pp. 21, 23.

${ }^{6}$ Henderson, op. cit., p. 313; North American Review, vol. clxxvi, p. Ige.

Wellington, Despatches, vol. i, pp. 637 et seq., Canning to Wellington, 8 November, 1822 . 
disorder in Spain had been especially favorable for the expansion of British commerce in South America. ${ }^{1}$ Characteristic of the restrictive and exclusive colonial system of European countries in the seventeenth and eighteenth centuries, the Spanish government tried to monopolize all trade with the colonies to the exclusion of all other nations; ${ }^{2}$ while Canning's first concern was to promote and protect British trade with Spanish America. ${ }^{3}$ During the eighteenth century the Spanish policy of colonial trade monopoly was somewhat compromised, partly through the influence of foreign residents in the colonies, and partly through a deliberate policy of the government." As early as 1713 , at the close of the War of the Spanish Succession, Spain granted to England in the Asiento Treaty: (a) the monopoly of the slave trade with Spanish America for a period of thirty years; ${ }^{b}$ (b) the right to bring annually to Porto Bello 500 tons of merchandise. While the conscience of the civilized world was soon to render the slave trade monopoly of diminishing importance, the second trade privilege was destined to grow more and more profitable and to affect within the century the attitude of England toward the whole Spanish colonial system. English merchants shipped many times 500 tons of merchandise every year, ${ }^{7}$ thus violating the terms of the Asiento Treaty, a circumstance which helped to bring on the War of Jenkins' Ear in 1739. But at the close of the war the treaty was

I Stapleton, Life of Canning, vol. ii, p. 10.

2 Latané, op. cit., pp. 6 et seq.

- Temperley, op. cit., p. 177.

- Chapman, op. cit., p. 458.

- Hill (D. J.), A History of European Diplomacy, (New York, 1914), vol. iii, pp. 333 .

- Ibid.

'Latané, op. cit., p. 14. 
renewed for a period of four years. Other European nations entered the field of South American trade in defiance of Spanish prohibitions. ${ }^{1}$ Thus the taste of the South Americans for the products of a wider civilization was stimulated $;^{2}$ and the Spanish colonists grew correspondingly impatient with the trade restriction. of their mother country. They were, therefore, as likely to welcome freedom of trade as the European states which coveted the opportunities of the South American market.

A new Anglo-Spanish trade agreement was made in 1810, when the Spanish government granted permission to Great Britain to trade with the Spanish-American colonies in return for mediation between Spain and the colonies. ${ }^{3}$ Although the Spanish government decided not to employ British mediation, Great Britain nevertheless insisted upon the continuation of that commercial intercourse, ${ }^{4}$ not finding it "practicable to withdraw commercial capital once embarked in Spanish America." s

According to Castlereagh's instructions to the British plenipotentiary at the Congress of Verona, he was to call the attention of the congress " to the intercourse which, for a long period of years, has subsisted between Great Britain and the Provinces of Spain in America, .... and the impossibility of its being obstructed or checked, without the certainty of rousing the utmost spirit of discontent in the commercial world." "Such instructions compel the con-

1 Hall (B.), Extracts from a Journal Written on the Coasts of Chili, Peru, and Mexico, (Philadelphia, I824), vol. i, p. 253.

s lbid.

3 British and Foreign State Papers, vol. xi, p. 5 r.

- Ibid.

SIbid.; F. O., South America, I822-1823, Communications with France and Spain relating to the Spanish-American colonies, no. I.

- F. O., Continent, Verona, September-December, I822, Castlereagh, Memorandum; $c f$. ibid., September-October, 1822, Wellington to Canning, 21 September, I822, no. 3. 
clusion that when, at the Congress of Verona, the British government would not surrender its "independent discretion to act according to circumstances," 1 the desire to satisfy the commercial interests constituted a dominant motive of its policy.

So great had grown the volume of British trade with Spanish America during the Napoleonic period that Spain felt it necessary to induce the British government to maintain a policy of neutrality between Spain and her colonies, fearing that otherwise commercial motives might induce Great Britain to support the cause of South American independence. $^{2}$ It was understood, however, that the maintenance of strict neutrality should in no way imply a prohibition of commercial intercourse between Great Britain and the Spanish colonies. ${ }^{3}$ Anglo-Spanish treaty relations seemed, therefore, to assure the continuance of British trade with Spanish America. But should France or the Alliance interfere, a great part of that trade might pass into the hands of France. It was that which Canning was determined to prevent. ${ }^{4}$

An idea of the value and growth of England's South American trade during the period in question is afforded by the following statistics.

Official annual value of the exports from Great Britain to the Spanish colonies on the continent of America from 1807 to 1815 :

'F. O., Continent, Verona, September-December, 1822, Castlereagh, Memorandum.

${ }^{2}$ Stapleton, Life of Canning, vol. ii, p. 10.

Ibid., p. II.

- Bigelow, (J.), American Policy, (New York, 19r4), pp. 44-45; Tower (C.), Essays, Political and Historical (Philadelphia, 1914), p. 15. 


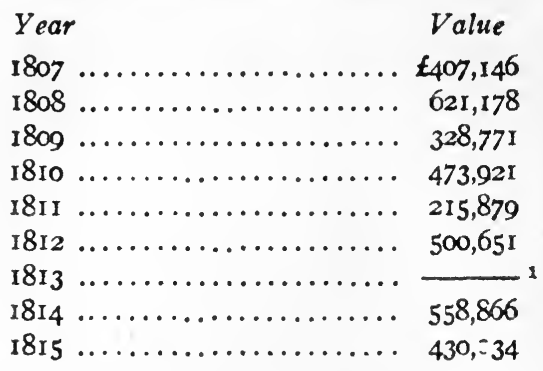

A comparison of the above figures with those of the British exports to the same market from 1822 to 1827 will reveal a most astonishing increase in the annual value of that trade: ${ }^{2}$

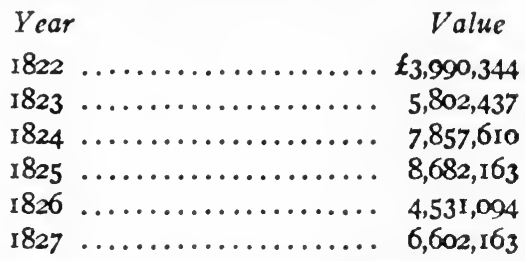

British imports for the same period inclined toward greater uniformity in their annual value. At the same time the value of the imports was far less than that of the exports, the balance of trade remaining throughout strongly in favor of Great Britain. The reason for this is found in the industrial inequality of England and South America.

British imports from the states of South America and Mexico from 1822 to $1827:^{3}$

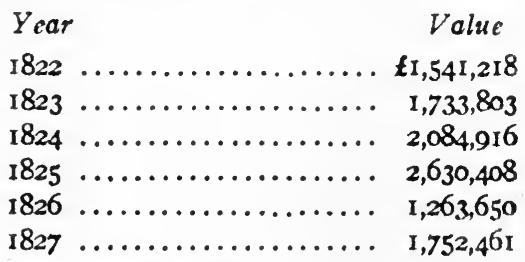

1 Records destroyed by fire.

- Yarliamentary Papers, (1828), vol. xix, p. 479.

lbid. 
The figures given above reveal two very significant facts. In the first place, the average annual value of British exports to Spanish America, not including Cuba, from I8ot


1822 to 1827 , their annual value amounted to $£ 6,244,333$. Secondly, the average annual value of the exports during the three years immediately preceding recognition of the South American states was $\mathfrak{f}_{5}, 883,397$, while the imports reached an average annual value of $\mathfrak{E}_{\mathrm{I}, 786,646 \text { for the same }}$ period. The average annual value of this trade for the period of three years immediately following the extension of recognition was, of exports, $£ 6,605,269$, and of imports, $\mathfrak{t I}_{\mathrm{I}}, 882, \mathrm{I} 73$.

These figures show that during the period from the treaties of Paris and Vienna to the outbreak of the FrancoSpanish war in 1823, British commerce with Spanish America had increased enormously. To the extent, therefore, that the interest of Great Britain in the fortunes of Spanish America was guided by economic motives, that interest was far greater in 1823 than it had been previous to the Treaty of Vienna. At the same time that Britain's commercial intercourse with Spanish America was becoming increasingly valuable, the Alliance was becoming increasingly insistent upon the execution of their policy of intervention. From these two circumstances one can easily understand the withdrawal of Great Britain from the Alliance, and her determination to use force, if necessary, to oppose intervention in South America.

A comparison of the value of British trade with Spanish America during the three years immediately preceding her recognition of some of the new states, with the value of that trade during the three years following upon recognition, reveals the interesting fact that the value of the trade during the latter period is only slightly greater than it was 
during the former period. The conclusion is thereby forced upon us that the extension of recognition to the new states was not compelled by any immediate economic necessity, since a normal volume of South American trade was alrearly in the hands of Great Britain. ${ }^{1}$ Recognition, then, made no immediate difference in the volume of that trace; but recognition of the new states by Great Britain was none the less desirable in British trade circles, lest the United States should presently gain a position of preference with those states. ${ }^{2}$

The inevitable post-war agitation for the extension of markets and for governmental encouragement of commerce took place in Great Britain soon after the close of the Napoleonic wars. ${ }^{3}$ Great Britain was then in a peculiarly favorable position to satisfy the markets of the world because of her industrial development. But her merchants suspected rivalry from France ${ }^{4}$ and the United States ${ }^{5}$ in the markets of South America; and consequently, it was to the South American markets which British traders gave their closest attention.

Strong pressure was brought upon the government byt the mercantile class of England for the improvement of commercial facilities in general during the decade following the Napoleonic wars. The substance of a petition presented by the merchants of London to the House of Commons in $1820,{ }^{8}$ was a demand for the removal of restrictions on foreign trade and for its improvement by various means.

1 The London Times, II November, 1823.

'2 Ibid., I2 September, I823.

- Annual Register, vol. 1xii, pp. 770 et seq.

- The London Times, 25 November, 1823.

- Ibid., 14 September, 1822.

- Porter, op. cit., vol. ii, pp. 152-156; Annual Register, vol. 1xii, pp. 773 et seq.

Ibid., pp. 770 et seq. 
A committee of Parliament was appointed to consider " the means of maintaining and improving the foreign trade of the country." 1 In its report the removal of trade restrictions was recommended. ${ }^{2}$ At the same time an attempt was made to clarify and make more uniform the commercial laws of the country. ${ }^{3}$

In an article on South America in Bell's Weekly Messenger, ${ }^{4}$ the commercial importance of South America was heavily stressed. In fact, it was the first of a series of articles aiming to acquaint Englishmen with those countries and with their commercial value to England: "As to her particular importance to the merchants and manufacturers of Great Britain, it may here be generally observed, that the greatest nation in the world must necessarily derive the greatest benefit from the creation of a new market." ${ }^{5}$

In a petition of London merchants to the Board of Admiralty in September, I822, it was pointed out that:

(a) The volume of the South American trade had vastly increased.

(b) The protection afforded American shipping by the government of the United States would give the American citizens the precedence in markets which Great Britain would consequently lose.

(c) Convoy for British merchant vessels ought, therefore, to be provided. ${ }^{6}$

On 2I July, I823, twenty-one representative merchants of London petitioned Canning to appoint commercial agents to the various states of South America, so as to place

1 Porter, op. cit., pp. 773 et seq.

2 Ibid.; Parliamentary Papers, (1820), vol. ii, pp. 367 et seq.

- Annual Register, vol. 1xiii, p. 77.

23 December, 1821.

5 Ibid.

- The London Times, 14 September, 1822. 
British commercial interests in those countries on the same footing as the interests of the nations which had already, appointed official commercial repsesentatives. The British, they asserted, had already some eighty establishments in various parts of South America, and investments of several millions sterling. ${ }^{1}$ It seemed clear to the merchants that their hopes of a flourishing commerce with the new states would go glimmering unless the government took some steps for its safety and promotion.

Merchants and shipowners petitioned the government to improve the political relations between England and Latin America in the interest of commerce. The Liverpool Shipowners' Association petitioned " The Lords of His Majesty's Most Honourable Privy Council" that, in view of the increasing demand for British goods in South America and the increasing commerce with that continent, and since those colonies were practically independent, there might be established with them such political relations as would "secure the freedom and safety of our trade on a permanent and favourable foundation." ${ }^{2}$ The merchants of the same city sent in a petition of similar tenor, supporting it with the argument that the abundant riches of South America, its large population of fifteen millions, the consumption by these millions annually of $f_{13}, 000,000$ worth of European manufactures, and the increasing magnitude of British trade with South America, deserved the attention of the government, and pointing out that during the years $1820-1821$, and to the first week in May, 1822, no less than I55 vessels cleared from British ports for Buenos Ayres, Chile, Peru and Mexico, and that the British exports were mostly woolens, cotton and linen. ${ }^{3}$

1F. O., South America, 1822-1823, Petition of Sundry British Merchants, 21 July, I823; the London Times, I2 September, I823.

${ }^{2}$ F. O., South America, 1822-18z3, Memorial of Liverpool Shipowners' Association, 9 May, 1822.

-Ibid., Memorial of the Liverpool Merchants, June, 1822. 
In another petition from the merchants and shipowners, jointly, it was argued that the establishment of favorable political relations with the new South American states was rendered the more urgent by the announced intention of some of those states, notably Colombia, to allow commercial privileges in the order of recognition. ${ }^{1}$

From the manufacturing city of Glasgow came another petition signed by sixty-one representative merchants and manufacturers. They declared that "the commercial interests of the United Kingdom, in all their most important branches," were most " materially affected by the state of the intercourse with that interesting part of the Globe" [South America]. In order to satisfy their commercial interests and in order to promote " that universal confidence necessary for commercial intercourse," they urged upon the government the early consideration of the recognition of South American independence. ${ }^{2}$

The Manchester Chamber of Commerce, in its petition, pointed to the increasing volume of trade with South America as justifying the appointment of consular agents ${ }^{3}$ to which Canning replied that the matter was under consideration." The Belfast Chamber of Commerce not only requested the appointment of consuls in the several ports of South America, but also urged the government to acknowledge the independence of the new states. ${ }^{5}$

That the merchant class of Great Britain feared the com-

'F. O., South America, I822-1823, Memorial of Merchants and Shipowners of Liverpool, July, I8az.

2 Jbid., Memorial of Merchants and Manufacturers of the City of Glasgow, 1822 .

3 Ibid., Application of the Manchester Chamber of Commerce for the Appointment of Consuls in South America, 14 August, 1823.

Ibid., Canning to Stanley, I9 August, 1823.

- Ibid., Petition of Belfast Chamber of Commerce, 26 August, 1823. 
mercial rivalry of France is again evidenced by the fact that on 22 November, I823, a committee of two, representing the London merchants, called on Canning and Huskisson to find out what was the attitude of France relative to South America. They were told that France did not seem to have any designs on South America, and that there was no immediate danger to British commerce with the South American states. ${ }^{1}$ But the London Times remained skeptical as to the intentions of France, asserting that the French were laying their plans on American soil, where they could not be so closely watched by their jealous European rivals, and denied that France had "any more right to interfere for the destruction of the independence of New Spain, than we have to interfere for its protection." 2

The London Times never tired of giving vigorous support to the claims of the merchant class, and it was ablyt seconded by other important papers. It pointed out that the offer of the Spanish-American states to accord priority of commercial advantage to foreign states in the order in which they might extend recognition, made early recognition imperative. ${ }^{3}$ It attributed to that offer "the readiness with which the North American Republic" caught "at the promised good, by hastening her formal act of recognition," and threatening "thus to forestall the merchants of Great Britain in the trade with South America." ${ }^{4}$ The difficulties and inconveniences experienced by British merchants because of having no officially accredited agents in South America, as well as the large amount of capital invested in trade with that continent, demanded an early recognition of

1 The London Times, 25 November, 1823.

Ibid., I9 December, 1823.

s/bid., I2 September, I823.

4 lbid. 
those states. ${ }^{2}$ Immediate action seemed especially necessary since France was suspected of a plan to intervene in South America in behalf of Spain, and evidently to secure from Spain, in compensation for her services, an agreement " that France should be the favored nation in her trade with the Spanish colonies to the exclusion of all others; out of which, too, would grow the establishment of the French Bourbons in complete supremacy over Spain both transmarine and European." ${ }_{2}$ There must be no union of French and Spanish Bourbons in the nineteenth century any more than in the eighteenth.

A new conception of the relation of government and business was plainly evident in the pressure which the commercial element brought upon the government. It was a conception characteristic of the new industrial age; namely, that the government should confine its activities to the encouragement of private initiative and the protection of private business. ${ }^{3}$ The insistent demands that were made upon the British government for recognition of the new states proceeded from a growing desire for the government to provide the opportunities of free and unrestricted individual enterprise. "The mercantile body has an indefeasible claim upon the government, that its fears should be tranquillized, its judgment guided, and its interests in every way protected," declared the London Times." The balance of power and commercial opportunity were equally at stake. Protection of the former would preserve the latter, especially in the case of the South American continent. Thus commerce and public policy were conveniently

The London Times, 12 September, I823.

21 bid.

sheyney (E. P.), Industrial and Social History of England, (New York, 1920), pp. 192 et seq.

- 22 September, 1823. 
interdependent. The danger to both seemed especially imminent in the autumn of 1823 . The realization of that danger was reflected in the vigor of the following editorial comment :

One security against French officiousness might perhaps be an early recognition of the South American states by this government. A shield would thus be raised before the new republics upon which the House of Bourbon would hardly dare to strike. . . . Let meetings be held in every part of England, and let the feelings of the commercial interest upon every point connected with maritime and colonial policy as involved in the present contest, be carried so strongly and distinctly to the throne, that His Majesty's Ministers may be enabled to display a moral power in arms against French encroachment, too mighty for the House of Bourbon to encounter. ${ }^{1}$

The commercial and political freedom of South America " concerned a British interest of the highest order; for the liberty of South America and the commerce of South America are important and precious to Great Britain." 2 The commerce of Great Britain with South America was considered "as free and open" to the British in 1823 as her commerce with any independent European state. ${ }^{8}$ Of so great an advantage, France would have no right to deprive Great Britain."

About a month before the news of the Monroe Doctrine arrived in England, the London Times expressed an editorial view that was similar to the spirit and purpose of the political principle of that policy. In both instances the

1 The London Times, 22 September, 1823.

$2 /$ bid., 20 September, 1823.

3 Ibid., II November, 1823.

4 sbia. 
independence of the South American states was insisted upon, and that their independence must be protected against foreign interference. But while the United States had extended recognition to them, Great Britain had not yet done so. It was in urging British recognition of their independent status that the Times editor anticipated the political principle of the Monroe Doctrine:

But without touching the question of the propriety of the formal recognition of the independence of the American states, let us take them simply as they are, . . a as independent de facto ... and trade with them in that character; no one can deny it; and that is their present condition, and it has been effected by no operation, or even mediation, of ours: it is the work of their own hands. "The courts of the North," it is said, "are about to publish a non-recognition of the independence of the American states." The courts of the North might publish a non-recognition of the light of day, or the darkness of the night; but the fact that day is light and night dark, are none the less true; neither can the present separation and independence of South America be altered by the negation of all the Powers and Princes of Europe. ${ }^{1}$

The same attitude was reflected in President Monroe's Message of 2 December, 1823 :

But with the Governments who have declared their independence we have, on great consideration and on just principles, acknowledged, we could not view any interposition for the purpose of oppressing them, or controlling in any other manner their destiny, by any European power in any other light than as the manifestation of an unfriendly disposition toward the United States. ${ }^{2}$

While it would not always be good diplomacy for the

- The London Times, 18 November, 1823.

' Richardson, op. cit., vol. ii, p. 218. 
government to speak boldly in reference to the economic interests of the country, the press is not thus restrained in the expression of a country's motives. The following quotation from Bell's Weekly Messenger on the South American situation as it appeared in December, I823, is a very straightforward statement of the motives which actuated a large and important group of British subjects:

Upon the whole, we are certain that we have the right to resist this confederate attempt by the Allied Powers to establish a universal despotism, and to oppose this league of Kings to defend themselves against all reforms, responsibility and revolution. And we are equally certain that it is our duty to do so. Our commerce is vitally concerned. If South America be now shut against us, it will stop that progress in our cotton, woollen, linen and silk manufactures, by the effect of which we are gradually recovering from the consequences of the war. ${ }^{1}$

But economic motives were not confined to the manufacturers and merchants. When in 1823 Spain was trying to negotiate an English loan, the bankers demanded tite recognition by Spain of the independence of her South American colonies as a condition upon which the loan would be granted. ${ }^{2}$ On the other hand, the revolutionary authorities seemed to experience no difficulty in raising large English loans in furtherance of their cause. ${ }^{3}$

It must not, however, be supposed that it was all smooth sailing for the merchants and manufacturers who saw in South American independence a source of increased commercial and industrial opportunities. Opposed to them

${ }^{1}$ Bell's Weekly Messenger, 21 December, 1823; cf. The Examiner, 28 December, 1823. The Italics are mine.

The London Times, 23 December, 1823 .

3 Camb. Mod. Hist., vol. x, p. 307. 
were those who saw in the new industrial class the rising aristocracy of wealth. A good example of such opposition is the following indictment fulminated against the merchants by Cobbett's Political Register:

From the nature of things, the advantages to England from the independence of South America would be very great, and would be almost exclusive. When I say England, here, I do not mean the people of England in general. I mean more particularly the Jews and Jobbers; I mean this odious aristocracy, and the almost as odious aristocracy of the merchants. The main body of the people would continue to be what they are now ; that is to say, the most wretched creatures in Europe. But the Jews and Jobbers of Change Alley and the greedy merchants and big manufacturers would profit largely. ${ }^{1}$

As the moment of France's triumph in Spain was approaching, and as her intervention in South America appeared more and more possible, ${ }^{2}$ the pressure of the merchants increased, while Canning's po zularity was growing among this class of his fellow-citizens. ${ }^{3}$ This increase of his popularity was unmistakably due to signs of yielding to their demands; as, for instance, his promise in reply to a merchants' petition, 22 August, 1823, that commercial agents would soon be sent to the South American countries.* The fulfillment of this promise in the autumn of $1823^{5}$ was characterized as " a kind of half-step to appease mercantile alarm, and to prepare the ground of opposition to the pro-

1 Cobbett's Political Register, vol. xlviii, p. 470.

The Examiner, 12 October, 1823.

3 Annual Register, vol. 1xv, p. 146.

Ibid.; F. O., South America, 1822-1823, Planta to Marragat \& Son, 22 August, I823; cf. ibid., Planta, Circular to Merchants, 17 October, 1823.

- Stapleton, Life of Canning, vol. ii, pp. 28, 33; Rush (R.), The Court of Londor, (London, 1873), p. 408. 
bable early results of Bourbon policy, principle, and ambition." 1

Ascendancy of French influence at the court of Madrid was not the only source of danger to British commerce with the Spanish-American states. Piratical attacks on British shipping in the West Indies were a real obstacle to commerce and a humiliating defiance of British naval prestige. ${ }^{2}$ Even Spanish warships captured British trading ships and brought them to port where they were condemned as prizes. ${ }^{3}$ A notable case in point was the attack on the "Lord Collingwood." " The reason given for the condemnation of the vessel was that it was found trading with the rebels of Buenos Ayres. ${ }^{5}$ As a matter of fact, there was found not the slightest trace of Spanish authority in that colony. The action of the Spanish authorities in condemning the "Lord Collingwood" was in open violation of an earlier agreement between Great Britain and Spain to the effect that if the former would not prevent, through measures of recognition, a possible amicable arrangement between Spain and her colonies in America, Spain, even though she might regain those colonies, would never reestablish the old exclusive system. ${ }^{7}$ The depredations on British commerce were

The Examiner, 28 September, 1823.

'Stapleton, Some Correspondence of George Canning, vol. i, p. 4h, Cabinet Circular, 15 November, 1822.

- F. O., Continent, Verona, November, 1822, Wellington, Memorandum on the Spanish Colonies in America.

Ibid., Spain, September-December, I8ea, Canning to William a Court, 18 October, 1822, no. 9.

$5 /$ bid.

- Ibid.; Stapletan, Life of Canning, vol. i, p. 168.

'F. O., Spain, September-December, 1822, Canning to William d Court, 18 October, 1822, no. 9; Annual Register, vol. Ixiv, p. 163; Stapleton, Life of Canning, vol. i, p. 168. 
committed not only by vessels sailing under the authority of the Spanish government, but, probably in the majority of cases, by pirates infesting the American waters and illegally using the Spanish flag. ${ }^{1}$

Great Britain could not very well submit to these repeated attacks on her South 'American commerce, nor could it be expected that she should submit to Spain's exclusive colonial system when the colonies enjoyed practically an independent existence. Applications for redress of grievances were made at Madrid, but without satisfactory response. $^{2}$

The offended dignity of a nation, combined with practical expediency, forced the government to adopt measures for the protection of British commerce. Politely, but none the less firmly, the Spanish government was informed of the British intentions. ${ }^{3}$ At the same time, and in order to give less offence to royal dignity, Great Britain protested her friendship for His Catholic Majesty, regarding herself as merely lending the influence of her own navy in the interest of Spain at the time when the latter was powerless to maintain order in the West Indian waters. ${ }^{4}$ But while Canning thus purported to act vicariously, as it were, for Spain, he was inclined to consider the Spanish colonies de facto independent states: "It is not necessary to declare war on Spain. Spain and her colonial empire are altogether separated de facto. She has perhaps as little direct and available power over the colonies which she nominally re-

1 Stapleton, op. cit., p. 169.

1 lbid.

${ }^{3}$ F. O., Spain, September-December, I822, Canning to William à Court, 18 October, I822, no. 9; ibid., William à Court to Canning, 24: December, I822; Stapleton, Life of Canning, vol. i, pp. I70 et seq.

4 Ibid.; F. O., Spain, September-December, I8z2, ICanning to William à Court, 24 November, I8z2, no. 16. 
tains, as she has over those which have thrown off her yoke." 1 The determination of the British government to employ naval forces for the protection of British commerce became a matter of serious concern at Madrid. The Spanish Ministry yielded to the extent of promising satisfaction for the ships that had been captured, to withdraw. prohibitions against trading with the colonies in America, and to make immediate payment of those claims which had already been acknowledged as valid. ${ }^{2}$ But Spain was quite powerless to furnish effective means of protection against piratical attacks. ${ }^{3}$ Several of the de facto governments of Spanish America were sufficiently strong to afford that protection; but they were not recognized, and could, therefore, not be held responsible. ${ }^{4}$ The irresponsibility of the new states, lacking British recognition, and the weakness of the Spanish government were the Scylla and the Charybdis which threatened the destruction of British commerce in South America, with France as an interested spectator. Some form of recognition of the de facto governments of South America seemed, therefore, to recommend itself. ${ }^{5}$

As if this combination of circumstances did not afford sufficient sources of affliction to British commerce, the British merchants thought that they saw in the United States a powerful rival for the trade with the southern con-

1 Stapleton, Some Correspondence of George Canning, vol. i, p. 53, Cabinet Circular, I5 November, I822; cf. F. O., Spain, SeptemberDecember, I822, 'Canning to William à Court, 30 November, I822, no. 19.

2 Stapleton, Life of Canning, vol. i, p. I76; F. O., Spain, SeptemberDecember, I822, William à Court to Canning, 9 November, I822, no. 30 ; ibid., Canning to William à Court, 30 November, 1822, no. 20; ibid., William à Court to Canning, 24 December, I822.

3 Stapleton, Life of Canning, vol. ii, p. I2.

4 Stapleton, Life of Canning, vol. ii, p. 3 .

${ }^{5} F$. O., Continent, Verona, I822, Wellington, Memorandum on the Spanish Colonies of America, no. 3I. 
tinent. This rivalry was at least potential; while the conditions attending recognition of the new states might easily determine which of the two powers should become the ultimate victor in the rivalry for commercial advantage. So far as the action of the United States was prompted by commercial motives, agencies of support were not wanting, as instanced by the following remark of an influential New. York newspaper:

A few days since we took the liberty, in a short paragraph, to call the attention of the American merchants to the vast markets about to be opened to the enterprise of the world, in the late American colonies of Spain; and we now beg leave again to direct their attention to the same subject, as we all are apprehensive notwithstanding our propinquity to them, that the vigilant and indefatigable John Bull will get the start of us. ${ }^{1}$

Such plain expression of American opinion must have given considerable concern to the commercial interests of Great Britain. The London Times considered the statement of sufficient importance to copy it. ${ }^{2}$ A few months later the Examiner called upon Great Britain to protect herself against the disgrace of being outrivaled by the Americans: "Could anything be more disgraceful in the British Ministers than to let the North Americans, with nothing like our motives, and some natural feeling to the contrary, get the start of us in establishing a profitable connection with the immense, fertile, and improving States of Southern America?" 3 The same thought was expressed by other British papers. ${ }^{4}$

1 New York Commercial Advertiser, 6 June, 1822.

- The London Times, 3 July, 1822.

${ }^{3}$ The Examiner, 30 November, 1823 .

4 Bell's Weekly Messenger, 20 June, I824. 
To maintain and to improve her commerce with the new states of South America was the ruling motive of Great Britain's American policy. ${ }^{1}$ The aim was clear. What means would offer the greatest possibility of success in its realization? A situation wherein figured the commercial interest of the United States, the political and commercial designs of France, the political watchfulness of the Alliance, and the irresponsibility of the unrecognized South American governments, was one which Great Britain could ill afford to entrust to "time and the course of events" to direct in her favor. Some direct action proceeding from a conscious purpose seemed imperative. The only question in the minds of British statesmen was the course of action. The recognition of the new states was growing in favor, and was urged by the press and by the commercial organizations. ${ }^{2}$ But even such an innocent measure had its pitfalls.

Although there remained not a vestige of Spanish authority in some of the Spanish colonies, would not British recognition, interpreted in accordance with Old-World diplomatic standards, be considered as an affront to Spain? Would it not increase the element of bitterness in the attitude of the continental powers toward Great Britain? Premature recognition of the South American republics by Great Britain might encourage the spirit of revolt within her own colonial possessions, ${ }^{3}$ which would, moreover, offer the enemies of Great Britain the most excellent opportunity for retaliation. Furthermore, British liberal opinion failed to see how Great Britain could consistently extend recognition to these states without at the same time

1 Bigelow, op. cit., pp. 44-45; Reddaway, op. cit., p. 23.

2 Stapleton, Life of Canning, vol. ii, pp. 14-15.

' Kasson (J. A.), The Evolution of the Constitution of the United States of America and History of the Monroe Doctrine, (Boston, 1904), p. 229. 
providing for a more liberal franchise at home. ${ }^{1}$ But there is a discouraging absence of any convincing evidence pointing to motives of political liberalism in Canning's attitude toward the whole South American question. Indeed, in a letter to the Comte d'Artois, the future Charles X, Canning: expressed his happiness at the restoration of His Royal Highness "to the palace of your ancestors." 2 The form of government which seemed the most desirable to the minds of Canning and Polignac, at the time of their famous October conference ${ }^{3}$ relative to the South American question, was the monarchical. ${ }^{4}$ The fact that the revolted colonies had organized themselves as republics on the model of the United States, may have been one reason for the reluctance of Canning to recognize the new states, both because of the aversion of the British governing classes for republicanism and because of the unpopularity of that form of government on the continent. Had Great Britain acted hastily in extending recognition to states organized as republics, such action might have caused the British government some very disagreeable complications in its relations with the continental powers.

The Examiner was fearlessly outspoken in its analysis of the government's motives in dealing with the South American question:

The whole secret, however, of their playing fast and loose with South America is this: our government is trying to trim between Legitimacy on the one hand, and its own commercial

1 Cobbett's Political Register, vol. xlviii, p. 474.

${ }^{2}$ Stapleton, Some Correspondence of George Canning, vol. i, p. 72, Canning to Monsieur, I February, I823.

3 Infra, pp. I22-I24.

- British and Foreign State Papers, vol. xi, p. 53, Memorandum of Conference between Canning and Prince de Polignac; Rush, op. cit., pp. $4 \mathrm{I} 2,468$. 
interests on the other. In principle, the invasion of South America would be no worse than the conquest of Spain; but then, as Mr. Brougham said, the former would touch our pockets, would be a fearful blow to British manufactures, trade, and revenue. Hence, this sudden respect for liberty and the independence of states-this horror of foreign powers interfering-this resolution to form a barrier against such interference. ${ }^{1}$

The view that the British government was actuated by motives growing out of political conservatism and commercial interest was not limited to British subjects. Richard Rush, probably as keen an observer and skillful diplomat as ever represented the United States at the Court of St. James, wrote his opinion of British motives to his chief. The statement is so important and so valuable in its bearing on the South American question that it deserves to be quoted at length :

As regards the principle of traffick, and especially as regards the whole range of her foreign trade, we have, it is true, witnessed of late on the part of this nation [Great Britain] an approach to more liberality than had governed her heretofore. It is possible that she may go farther in this policy; a policy irresistibly recommended, and, as she will not scruple herself to admit, forced upon her, by the changing circumstances of the commercial world. But as regards the principles of political freedom, whether in relation to herself or other states, we shall not find it easy to perceive as yet any such favorable alteration in her conduct. ... She at least perceives a crisis likely to come on, bringing with it peril to her own commercial prospects on the other side of the Atlantic, and to her political sway in both hemispheres. Hence probably some of her recent and remarkable solicitudes. The former war of twenty years more than once shook her prosperity and brought

1 The Examiner, 8 February, I824. 
hazards to her existence, though for the most part she was surrounded by allies. A second war of like duration with no ally for her in Europe might not have a second field of Waterloo for its termination. Such are the prospective dangers that possibly do not escape her. ${ }^{1}$

It is impossible to escape the conclusion that Canning's opposition to having the Spanish-American colonies pass into the hands of any other power but Spain was dictated by commercial motives. ${ }^{2}$ But, viewed from the diplomatic as well as the political standpoint, it would be singularly! fortunate for Great Britain could she discover the ways and the means of safeguarding her commercial interests in South America without the necessity of resorting to recognition for some time. There were three possible solutions to this difficult problem: first, an understanding with the government of the United States in opposition to the designs of France and the Alliance in South America; second, deferring recognition until Spain had recognized the independence of her own colonies; ${ }^{3}$ third, permitting Spain alone to attempt to regain her colonies, hoping that if Spain were successful in her attempt, such success would be achieved only through liberal concessions to the colonies in the form of greater economic freedom, or the "open door," from which British commerce would derive valuable advantages. But whether or not Spain would feel compelled to recognize the independence of her colonies, or be forced to proceed alone to attempt to regain them, would depend very much upon an understanding between the United States and Great Britain relative to the South American question.

1 Ford (W.IC.), John Quincy Adams, his Connection with the Monroe Doctrine, (Cambridge, I902), pp. 52 et seq.; Rush to Adams, I5 September, I823.

2 Henderson, op. cit., pp. $3 \mathrm{I} 6$ et seq.

${ }^{3}$ F. O., Spain, September-December, I822, William à Court to Canning, 28 December, I822, no. 62. 


\section{CHAPTER V \\ The Anglo-American Entente}

As early as November, I822, Canning had given thought to the matter of recognition of the republics of South America. In his Cabinet Circular of I5 November he pointed to the difficulties encountered in trading with these states as probably constituting the circumstances which would finally compel British recognition. ${ }^{1}$ After an enumeration of the obstacles placed in the way of British commerce by the Spanish authorities, he asked the question:

What resource have we but to take away all pretext for the enforcement of these absurd and absolute pretensions against us, by conferring on the colonies, so far as our recognition can do it, an independent instead of a colonial character, and thus cutting short all dispute as to Spain's colonial jurisdiction? No man can say that under such circumstances our recognition of these states can be indefinitely postponed. ${ }^{2}$

Such a step he considered as being "most justifiable towards Spain, most acceptable to her late colonies," and of very great benefit to Great Britain. ${ }^{8}$

But the circumstances relating to recognition were far more tangled than the November Cabinet Circular seems to indicate. The decision of the Congress of Verona (in

1 Stapleton, Some Correspondence of George Canning, vol. i, pp. 56-57, Cabinet Circular, I5 November, 1822 .

2 Ibid., p. 57.

slbid. 
which Great Britain refused to concur) to coerce the Spanish Constitutionalists moved the British government to refrain from further increasing the difficulties of Spain through recognition of her American colonies. ${ }^{1}$ There was some doubt also whether the new states had developed sufficient force and stability to merit the recognition of their independence. ${ }^{2}$ The act of the British government in sending naval squadrons to the waters of the West Indies produced a salutary effect upon the Spanish government, which immediately promised redress of grievances and reparation of damages. ${ }^{3}$ This attitude of good intentions seemed to make immediate recognition unnecessary.

In December, I822, Canning announced to the government of Spain his intention of sending consuls to the various Spanish colonies in America for the purpose of protecting: British trade. ${ }^{4}$ On $3^{\mathrm{I}}$ March, 1823 , on the eve of the French invasion of Spain, Canning said in his letter to Stuart that "time and the course of events appeared substantially to have decided their separation from the Mother country." " With these two exceptions little attention was paid to the matter of recognition from the close of the Congress of Verona to the summer of I823, when European intervention in South America was threatening. ${ }^{6}$

The course of events which would decide the question of recognition referred mainly to the French invasion of

1 Stapleton, Life of Canning, vol. ii, p. I7.

${ }^{2}$ Stapleton, Some Correspondence of George Canning, vol. i, p. 38; Broderick and Fotheringham, op. cit., vol. xi, p. 216.

${ }^{3}$ Stapleton, Life of Canning, vol. ii, pp. I6-I7.

4 Ibid., p. I8; F. O., Spain, September-December, I822, Canning to William à Court, 9 December, I822, no. 35 ; ibid., South America, I822-I823, Planta to Lack, 7 December, I822.

5 Parliamentary Papers, (1823), vol. xix, pp. 59-60, Canning to Stuart, 3I March, I823; Stapleton, Life of Canning, vol. ii, p. I8.

- Ibid. 
Spain. ${ }^{1}$ It practically amounted to an announcement of the policy which Canning would pursue in the event of any effort by France or the Allies to intervene in America, or in the event that France should insist upon indefinite military occupation of Spain. During the summer of 1823 the "course of events" in Spain was becoming daily more favorable to France until it terminated in complete victory for the invaders and the restoration of King Ferdinand VII. At that juncture might occur the very event which both the government of Great Britain and that of the United States had long suspected-European intervention in South America. King Ferdinand, emboldened by success, would give such an enterprise his most active encouragement. France would profit, the old order would be victorious, and probably the old colonial system would be restored. England's position of influence among the states of Europe would be eclipsed by France, her commerce with South America seriously impaired. Even though the Alliance should not interfere, there was the threatening ascendancy of the United States in the western hemisphere. Such was the ominous spectre which British statesmen saw rising above the horizon of possibilities in the summer of 1823 .

Some of the South American republics had now been recognized by the United States. But recognition had not yet been accorded them by Great Britain - that other country to which they had cause to look as a shield of protection against the menacing threats of the continental powers of Europe. Would not British recognition now have been a most timely event? Would it not have convinced the European Allies that Great Britain and the United States were in accord on the Spanish-American question? Would

$1 F$. O., France, January-April, 1823, Canning to Stuart, 3I March, I823, no. 29. 
not the evidence of such an accord of the two English-speaking countries have been convincing of the futility of any attempt to enforce the Doctrine of Intervention in the former colonies of Spain? No attempt will be made to answer these questions here, but affirmative evidence is found in the failure of the Allies to intervene when they became aware of the later Anglo-American understanding of which we shall treat presently. Meantime it became clear to the British Foreign Office that to accord recognition to the Spanish-American republics during the summer of I823 would have been most inexpedient. ${ }^{1}$ It was, in fact, judged more difficult in the autumn of 1823 than in the autumn of $\mathrm{I} 822$ for Great Britain to accord recognition to these states as a counterpoise to the growth of French influence in Spain. If Great Britain had recognized the independence of the new states in 1822 , the act would have been interpreted by the Allies as a blow directed against the Constitutionalists in Spain. On the other hand, had recognition been extended in the autumn of 1823 , after Ferdinand and the conservative régime had been restored in Spain, it would have been deemed a blow at the very government in Spain which France and the Allies had supported and brought back into power. ${ }^{2}$ Such an act in the autumn of 1823 would have been in such complete defiance of, and so contradictory to, the policy of the Allies as to lead probably to an open break between them and Great Britain. ${ }^{3}$ Recognition, then, under these circumstances, must be the last recourse after all other means of protecting the new states from allied intervention had been entirely exhausted. To satisfy these aims an Anglo-American declaration of policy

1 Stapleton, Life of Canning, vol. ii, p. 22.

2 Ibid.

' ' emperley, op. cit., p. I79. 
suggested itself to Canning; ${ }^{1}$ and in seeking the cooperation of the United States he was one of the first English statesmen to appreciate the influence and value of a good understanding between the two countries. ${ }^{2}$

Notwithstanding the fact that the United States and Great Britain had only recently been at war, there was developing a friendly feeling between their governments during the years immediately preceding the issuance of the Monroe Doctrine. In an editorial on President Monroe's Message $^{3}$ of 3 December, I82I, the editor of the London Times delighted to dwell on the friendly feeling toward England of which the Message gave evidence: "It may. be satisfactory to add, that there is not an expression used toward Great Britain, in the several paragraphs wherein her relations with the United States are referred to, which indicates anything but the continuance of the most undisturbed and perfect harmony between the two governments." 4

The official attitude of the British government was no less favorable toward the United States. Canning in the course of an address delivered in Liverpool said with reference to Anglo-American relations: "Where a child, having perhaps displeased a parent-a daughter, for instance in contracting a connection offensive to that parent's feelings, some estrangement would ensue; but after a lapse, the irritation is forgotten, the force of blood again prevails, and the daughter and the mother stand together against the world." : Upon the passage in Canning's address the editor of the

${ }^{1}$ Stapleton, Life of Canning, vol. ii, p. 22.

- Hart, op. cit., p. 49.

${ }^{3}$ Richardson, op. cit., vol. ii, pp. 98 et seq.

4 The London Times, I January, I822.

${ }^{5}$ Quoted in the Morning Chronicle, 22 September, 1823. 
Morning Chronicle commented: "We hardly imagined that the time was so near at hand for imposing on the people of this country the necessity of cultivating the friendship of our American offspring as almost essential to our. own safety." 1 This statement leads one to the conclusion that Great Britain was not only well disposed toward the United States, but that she actually felt the necessity of an understanding with this country for the purpose of effective opposition to the policies of the Alliance. ${ }^{2}$ Even Rush was impressed with the favorable attitude shown by the British government toward his country. He communicated his observations to President Monroe under date of ${ }_{5}$ September, 1823 : “. . . . my most careful observation in England during my residence, had impressed me with the belief, that the present administration, with Lord Liverpool at its head, was as favorably disposed toward us as any that could be formed." 3

Circumstances, therefore, seemed auspicious for an Anglo-American accord on one of the greatest problems of that period. But two obstacles must be overcome before joint action could be possible : first, the traditional American policy of isolation; second, the difficulties that might arise from the fact that Great Britain and the United States stood, in 1823 , on a different footing in their relations with the new states of South America. During the initial interview between Canning and Rush in the summer of 1823 , relative to a joint Anglo-American declaration, the latter, desirous, undoubtedly, of paving the way for Great Britain's support of South American independence, reminded Canning of his reference to recognition of the South American

1 The Morning Chronicle, 22 September, 1823.

'Cobbett's Political Register, vol. xlvii, p. 715.

- Rush, op. cit., p. 387; Ford, John Quincy Adams, his Connection with the Monroe Doctrine, p. 54, Rush to Monroe. 
republics. ${ }^{1}$ That reference was contained in Canning's letter to Stuart, 3I March, I823. ${ }^{2}$ Not only did Rush entirely approve of Canning's views as then expressed, but he professed to see in that statement a purpose of preventing France from interfering with the progress of political emancipation in South America. ${ }^{3}$ It must have inspired belief in the possibility of some form of Anglo-American cooperation in behalf of South American independence, and disposed Rush to entertain any overtures with a view to such cooperation. But the plan of Rush was a similarity of policy through British recognition rather than a joint declaration of the two governments while remaining on a different footing in relation to the new states.

Some sort of understanding between the United States and Great Britain was becoming daily more necessary in the minds of the British Cabinet, ${ }^{4}$ and evidently more welcome to the United States, as the two governments witnessed the growing ascendancy of France in the Peninsula. ${ }^{5}$ Apprehensive of the danger of a combined attack by France and the other members of the Alliance, Canning conceived of a plan to prevent it. ${ }^{6}$ If he were successful in preventing an agreement among them to attack South American independence, he would thereby also prevent an armed conflict between England and the continental powers. ${ }^{7}$ For if the Alliance had seriously aimed at the subjugation of South America, England would have been equally determined to prevent it; and in that case war would have been

${ }^{1}$ Rush, op. cit., p. $36 \mathrm{r}$.

2 Parliamentary Papers, (1823), vol. xix, pp. 59-60.

${ }^{3}$ Rush, op. cit., p. $36 \mathrm{I}$.

${ }^{4}$ Ibid., p. 38r.

Ibid., p. 389.

- Stapleton, Life of Canning, vol. ii, p. 23.

"Stapleton, Life of Canning, vol. ii, p. 23. 
unavoidable. The desire of Canning to maintain peace, and at the same time to protect the interests of Great Britain in South America, accounts for his haste in sounding Rush on the possibility of a joint declaration of Great Britain and the United States. ${ }^{1}$

Canning's knowledge of the sympathy of the people of the United States with the independence movement among the Spanish colonists gave him sufficient reason to believe in the willingness of the United States government to enter into some such engagement with Great Britain. ${ }^{2}$ The political liberalism of the United States was about to be capitalized in support of the commercial interests of Great Britain; or, the commercial interests of Great Britain were about to be employed in the interest of political liberalism in the western hemisphere. Whichever of these views one takes, the fact remains that the Anglo-American entente on the South American question had its immediate origin in, and proceeded from, the commercial interests of the one country and the political liberalism of the other. ${ }^{3}$

It was in the course of the interview between Canning and Rush on I6 August, I823, that the former asked Rush what the government of the United States would think of "going hand in hand with England in such a policy." " Rush had just expressed his approval of, and admiration for, the position assumed by Canning in reference to any ulterior: designs which France might have upon the Spanish colonies. It was now apparent that the United States and Great Britain viewed the Spanish-American question in the same light-to the extent that both were opposed to European in-

1 Stapleton, op. cit., vol. ii, p. 23.

- Henderson, op. cit., p. 317.

- Tower, op. cit., pp. 17-18.

4 Rush, op. cit., p. 362. 
tervention. What seemed more reasonable and expedient than for them to present some outward and visible evidence of their common understanding in the matter? Canningt saw in such an understanding an effective check to any project of European interference. Said Canning:

The knowledge that our two countries ... hold the same opinions, would, by its moral effect, put down the intention on the part of France, if she entertained it. This belief was founded ... upon the large share of the maritime power of the world which Great Britain and the United States shared between them, and the subsequent influence which the knowledge of their common policy on a question involving such important maritime interests, present and future, could not fail to produce on the rest of the world. ${ }^{1}$

Canning's suggestion of a joint Anglo-American policy presented questions so intricately bound up with the foreign policy of the United States that Rush felt impelled to refer the whole matter to his government before committing himself. $^{2}$ Acceptance of Canning's invitation to joint action would have produced a new departure in the policy governing the relations of the United States and Europe. It would have been contradictory of the policy of isolation. The foreign policy of the United States was therefore involved. Should it be a policy of association with a European power or powers, or should it remain one of isolation and aloofness?

Meanwhile, Rush was desirous of ascertaining where Great Britain stood in relation to the new communities, " and especially on the material point of acknowledging" their independence." 3 It was already the purpose of Rush

1 Rush, op. cit., pp. 362-363, 366.

2 Ibid., pp. 363, 380-38r, 393.

3 Rush, The Court of London, p. 363 ; cf. ibid., p. 393. 
to bring about, if possible, British recognition of the new: states, so that not only would Great Britain and the United States stand in a similar relation to these states, but the interest of the British government could thus be made to rest upon the broad basis of principle and sympathy. Under such conditions, not only would the government of the United States assume a more favorable attitude toward the policy of concurrent action, ${ }^{1}$ but such action would be rendered more effective, and the foreign policy of this country would escape the humiliating imputation of being an instrument in support of the commercial interests of Great Britain.

To the inquiry made by Rush with reference to the recognition of the South American republics, Canning replied that Great Britain would never again attempt to settle the dispute between Spain and her colonies; ${ }^{2}$ but if such settlement should be brought about, Great Britain would not oppose it. ${ }^{3}$ He agreed with Rush that there was no longer any opportunity for Spain to regain her colonies. ${ }^{4} \mathrm{He}$ would, however, place no obstacle in the way of a settlement between Spain and her colonies that would secure to Spain special commercial advantages. ${ }^{5}$ In regard to recognition, Canning stated that his government was on the point of taking certain steps of a "preparatory nature," but that these steps would still leave his country free to extend or withhold recognition as circumstances might require. ${ }^{6}$

So far, the discussion of the British Foreign Secretary and the American Minister had been informal and limited

1 Rush, op. cit., p. $3 \&_{4}$.

s lbid., p. 363.

3 /bid., p. 364

- Ibid.

Ibid., p. 365.

- Itid. 
to the preliminary stage of ascertaining one another's position relative to Latin America. On 22 August, setting forth the British position, and at the same time appealing, for an Anglo-American understanding, Canning asked "if the moment has not arrived when our two governments might understand each other as to the Spanish-American Colonies; and if so, whether it would not be expedient for ourselves, and beneficial for all the world, that our principles in regard to them should be clearly settled and avowed. That as to England she has no disguise on the subject."

Then, proceeding to explain the position of England categorically, Canning stated that his government conceived as hopeless the recovery of the colonies by Spain $;{ }^{2}$ that the recognition of these colonies as inciependent states would be determined by time and circumstances; ${ }^{3}$ that England would place no obstacle in the way of settlement by amicable negotiation between Spain and her colonies; that England disclaimed all desire to obtain possession of any portion of the colonies; ${ }^{5}$ and that she could not see with indifference the transfer of any portion of the colonies to any other. power. ${ }^{-~ I n ~ c a s e ~ t h a t ~ t h e ~ U n i t e d ~ S t a t e s ~ " a c c e d e d ~ t o ~ s u c h ~}$ views, a declaration to that effect on their part concurrently with England, would be the most effectual, and least offensive, mode of making known their joint disapprobation of contrary projects." ?

Rush must have had his doubts as to any amicable negotiations between Spain and her colonies. ${ }^{8}$ But an Anglo-

1 Rush, op. cit., p. 376.

Ibid.

Ibid., p. 377.

4 Ibid.

slbid.

- lbid.

I lbid.

8/tid., p. 378 . 
American declaration to the effect that no impediment was to be placed in the way of such negotiations would be only a harmless diplomatic courtesy. On 23 August Canning's propositions were despatched to Secretary Adams, together with the comment by Rush "that this Government has the subject of Canning's proposition much at heart, and certainly his note bears upon the face of it a character of earnestness, as well as cordiality, towards the Government of the United States, which cannot escape notice." 1

While the question of concurrent action was being referred to the government of the United States, the course of events in Europe called for quick decision. Canning informed Rush on 26 August that he had heard of a proposal for a new congress of the powers for the special purpose of dealing with the Spanish-American question. ${ }^{2}$ There could be no doubt as to the results should the SpanishAmerican situation be left to such a congress for solutionsuppression of the independence movement, restrictions on trade, destruction of the balance of power. Confronted by such a crisis as that to which the holding of the proposed congress seemed to point, the governments of Great Britain and the United States must act quickly and decisively. So well did Rush understand the serious consequences of such a congress, so keenly alive was he to the necessity of resistance, and so well did his own attitude reflect that of his government that he replied almost immediately (27 August) to Canning's note of the 26th. He set forth in his reply that:

(a) The government of the United States would regard any interference in the affairs of Spanish America without the consent of the new states as objectionable. ${ }^{3}$

1 Rush, op. cit., p. 380.

Ibid., p. 382; Stapleton, Life of Canning, vol. ii, p. 20.

3 Rush, op. cit., p. 383. 
(b) He considered the convening of a congress for the purpose of deliberating upon the affairs of Spanish America "as a measure uncalled for, and indicative of a policy highly unfriendly to the tranquillity of the world." 1

(c) The government of the United States would never look with indifference upon any attempt to exercise European jurisdiction over the new states, which were of right now entitled to regulate their own affairs. ${ }^{2}$

(d) If England were ready to acknowledge the independence of the new states, that fact would not only prompt the United States to early action, but would also facilitate negotiations with Canning. ${ }^{3}$

Despite the urgency of early action on the part of the two governments, some delay was experienced, partly because the British government hesitated in extending recognition, partly because of the necessity of referring to Washington for instructions. The fact that Rush lacked powers for immediate procedure with negotiations was a source of much disappointment to Canning, who confessed his inability to wait for instructions to arrive." Meantime the government of Great Britain must have a free hand to deal with whatever emergency might arise from the French invasion of Spain. ${ }^{5}$ Since the course of events during the interval might make necessary some action, diplomatic or otherwise, on the part of the British government, Rush was asked by Canning to consider the proposition of concurrent action " not as a proposition already made, but as evidence of the nature of one which it would have been his desire to make." ' This change of view left Canning free to take

${ }^{1}$ Rush, op. cit., p. 383.

I Ibid.

Ibid., p. 384.

4 Ibid., pp. 384-385.

1 lbid., p. 385 .

- Ibid. 
whatever action would be consistent with British policy and interests, awaiting instructions from Washington.

A change of view as to the binding nature of the proposition did not imply any change in purpose; for Canning continued as strongly desirous of the cooperation of the United States as before. In fact, in an interview with Rush on 18 September, Canning employed the pressure of skilled arguments to convince Rush and, through him, the government of the United States, of the timeliness and the necessity for some form of joint action. In reporting this interview to Secretary Adams, I9 September, Rush described the arguments in his own words:

The question was a new and complicated one in modern affairs. It was also full as much American as European, to say no more. It concerned the United States under aspects and interests as immediate and commanding, as it did or could any of the states of Europe. They [the United States] were the first power established on that continent, and now confessedly the leading power. They were connected with Spanish America by their position, as with Europe by their relations; and they also stood connected with these new states by political relations. ${ }^{1}$... Was it possible that they could see with indifference their fate decided upon by Europe? Could Europe expect this indifference? Had not a new epoch arrived in the relative position of the United States towards Europe, which Europe must acknowledge? Were the great political and commercial interests which hung upon the destinies of the new continent, to be canvassed and adjusted in this hemisphere, without the cooperation or even knowledge of the United States? Were they to be canvassed and adjusted . . . without some proper understanding between the United States and Great Britain, as the two chief maritime states of both worlds? ${ }^{2}$ ... He [Canning] had the strongest reasons for believing that

1 Rush, op. cit., p. 391.

$2 /$ bid., p. 392. 
the cooperation of the United States with England, through my instrumentality, afforded with promptitude, would ward off altogether the meditated jurisdiction of the European powers over the new world. ${ }^{1}$. . . Why then should the United States, whose institutions resembled those of Great Britain more than they did those of the other powers of Europe, and whose policy upon this occasion was closely approximated to her's, hesitate to act with her to promote a common object approved alike by both; and achieve a common good estimated alike by both. ${ }^{2}$

These were potent arguments. They were not only convincing of Canning's anxious desire for an Anglo-American understanding on the Spanish-American situation, but they were clearly intended to furnish some additional force of motive and to give a certain direction to the attitude of the United States relative to the situation. The community of interest of the United States and Great Britain, the special interest of the former as the first power in the western hemisphere, the reference to the similarity of their institutions, their maritime strength, the sure effectiveness of their combined action, and the justice and necessity of such action, were points to which the American statesmen must have listened with interest. Some of them must have sounded like echoes of earlier pronouncements of American policy; others encouraged the hope of its realization. The position assumed by Great Britain as expressed by Canning must have given such encouragement. Whether the government of the United States would act jointly with that of Great Britain to prevent European intervention in South America, or avail itself now of the opportunity to declare to the world the existence of a distinctly American policy, long maturing, the favorable attitude of Great Britain was

1 Rush, op. cit., p. 394.

Ibid., p. 395. 
no less necessary to render the policy of European exclusion effective.

Rush recognized in the policy of Great Britain something that harmonized with that of the United States, although he also saw something in it that was designed to benefit Great Britain. Yet, since the support of that policy would add strength to that of the United States, Rush was favorably disposed toward the acceptance of Canning's proposition for its practical effects. ${ }^{1}$ But a serious obstruction to any agreement looking to concurrent action still remained. It was Canning's unwillingness to acknowledge the independence of the new states of South America. To all the arguments which Canning had presented in the hope of persuading the United States to join her policy with that of Great Britain, Rush replied that the whole matter would come to a most satisfactory conclusion if only Great Britain would recognize the independence of these states. The European congress might meet afterwards, but it would be of no account. $^{2}$ If only Great Britain would extend recognition; Rush would consent, in the name of his government, to the "formal promulgation to the world" of that declaration to which Canning had invited him. ${ }^{3}$ But Canning was unyielding, believing, as he told Rush, that the new states did not yet possess sufficient internal stability to warrant British recognition." Moreover, Canning admitted, immediate recognition might cause his country some embarrassment, of which there was no danger in the case of the United States when the latter recognized the southern republics. ${ }^{\circ}$ He was evidently alluding to England's relations with the con-

I Rush, op. cit., p. 405.

Ibid., p. 396.

3 Ibid., p. 397.

4 Ibid., p. 398.

Ibid. 
tinental powers, and to the probable effect of immediate recognition upon those relations. ${ }^{1}$ The European situation was such as to demand, on the part of England, the exercise of diplomatic caution to avoid war. For England, then, favorable conditions for the recognition of the republics had not yet matured through "time and circumstances." The best that Canning could offer was a promise of future acknowledgment of their independence; ${ }^{2}$ but Rush was firm in his insistence upon its immediate recognition as the price of a joint declaration of policy.

The series of interviews between Canning and Rush relative to an Anglo-American declaration terminated rather suddenly on 8 October. ${ }^{4}$ In reporting the incident to Secretary Adams, Rush remarked:

At a conference with Mr. Canning on the day before yesterday, he said nothing of Spanish-American affairs, except barely to remark at parting, that he should send off consuls to the new states very soon, perhaps in the course of this month. ... Mr. Canning not having acceded to my proposal, nor I to his, we stand as we were before his first advance to me, with the exception only of the light which the interesting discussion may be supposed to have shed upon the dispositions and policy of England in this important matter. It appears that having ends of her own in view, she has been anxious to facilitate their accomplishment by invoking my auxiliary offices as the Minister of the United States at this court; but as to the independence of the new states of America, for their own benefit, that this seems quite another question in her diplomacy. ${ }^{5}$

1 Rush, op. cit., p. 405; swpra, pp. 100-101.

- Ibid., p. 405.

3 Ibid.

- Ford, John Quincy Adams, his Coxrection with the Monroe Doctrine, p. 56, Rush to Adams, Io October, 1823 .

Ford, John Quincy Adams, his Connection witk the Monroe Doctrine, pp. 56-57, Rush to Adams, to October, 1823. 
Canning refused immediate recognition of the South American states as a condition of a joint Anglo-American declaration not only because he considered such a step as diplomatically inexpedient, ${ }^{1}$ but also because of his own preference for the monarchical form of government and the unpopularity of republicanism in Europe generally. Although he may not have entertained any serious hopes of ever seeing the monarchical form of government substituted for the republican by the South American states, and although he would not insist upon such a change as a condition upon which Great Britain would grant recognition, ${ }^{2}$ nevertheless the fact that the new states were republics may have been the strong political obstacle to immediate recognition. The language of the Memorandum recording the conclusions of the Canning-Polignac conference respecting Latin America, 9 October, 1823, gives the impression of Canning's desire to see the monarchical form of government established by the new states. The last paragraph of the Memorandum represents Canning as having said that

however desirable the establishment of a monarchical form of government, in any of those Provinces might be, on the one hand, or whatever might be the difficulties in the way of it, on the other, his government could not take upon itself to put it forward as a condition of their recognition. ${ }^{3}$

However, any aversion which Canning might have had for the republican form of government would probably have yielded to the pressure of the commercial interests had the act of recognition been diplomatically safe.

1 Stapleton, Life of Canning, vol. ii, p. 22; Temperley, op. cit., p. 179; supra, p. 107.

British and Foreign State Papers, vol. xi, p. 53.

- Ibid., Memorandum of Conference between Canning and Prince de Pohignac; cf. Rush, op. cit., pp. 412, 468. 
It was the failure to reach an agreement with $R$ ush that made it necessary for Canning to seek other means through which a practical solution of the Spanish-American question might be found,-a solution that would safeguard the interests of Great Britain in Spanish America. For this purpose Canning now turned to France, the one nation from which he had the most to fear. ${ }^{2}$

Rush suspected, in his despatch to Secretary Adams on Io October, that some "fresh explanations with France" were the cause of the sudden termination of Canning's interest in an Anglo-American concert of policy. ${ }^{2}$ He was confirmed in this belief when, on 24 November, Canning told him that, owing to their failure to reach an agreement on the policy of concurrent action, and because " time and the pressure of events did not allow of an indefinite postponement of a matter, which was liable, from day to day, to be brought into immediate discussion by other Powers," he had found it indispensable to come "to an explanation with France." 3

It was during the early part of October that Canning and Prince de Polignac had these conversations which finally concluded with the agreement of 9 October. ${ }^{4}$ In this agreement the French government admitted the hopelessness of restoring the American colonies of Spain to their former relation of loyalty to their mother country; ${ }^{5}$ and

Stapleton, Life of Canning, vol. ii, p. 26.

- Ford, John Quincy Adams, his Connection with the Monroe Doctrine, p. 57, Rush to Adams, Io October, 1823.

- Ford, John Quincy Adams, his Connection with the Monroc Doctrine, pp. 62 et seq., Rush to Adams, 16 November, 1823; Rush, op. cit., pp. 409-410.

- British and Foreign State Papers, vol. xi, pp. 49-53; F. O., Russia, January-December, 1823, Canning to Bagot, 3 December, 1803, no. 20; Parliamentary Papers, (1824), vol. xxiv, pp. 645 et seq.

I Ibid. 
Prince de Polignac abjured for France any "design of acting in any case against the colonies by force of arms." 1 These admissions on the part of the French representative considerably lessened the chances of any difficulty arising out of British recognition of the new republics, ${ }^{2}$ and virtually acknowledged the right of the Spanish-American colonies to independent sovereignty. ${ }^{3}$ As a result of the Canning-Polignac agreement, British apprehensions were fully allayed. Canning no longer had any reasons to fear either armed intervention by France in South America or any interruption of the peace of Europe on that account." It was a great victory for Canning at the expense of France, whose government now manifested a yielding attitude. ${ }^{\text {a }}$ When the news of the Canning-Polignac agreement reached the courts of the allied powers, their reaction to it was one of displeasure. ${ }^{\circ}$

Of the significance of this agreement as a solution of the Spanish-American problem which Canning and Rush had aimed to solve by a joint declaration, Canning wrote to Rush :

... I flatter myself that neither you nor we shall have to lift our voice against any of the designs which were apprehended a few months ago. ${ }^{7}$

Thus Canning interpreted his agreement with Prince de

1 Parliamentary Papers, (1824), vol. xxiv, pp. 645 et seq.

Ibid.

3 Ibid.; Stapleton, Life of Carring, vol. ii, p. 33.

- Ibid.; Ford, John Quincy Adams, his Connection with the Monroe Doctrine, p. 64 , Rush to Adams, 26 November, 1823.

s Ibid.

- Stapleton, Life of Canning, vol. ii, p. 33.

- Ford, John Quincy Adams, his Connection with the Monroe Doctrime, p. 65 , Canning to Rush, 13 December, 1823. 
124 BRITISH POLICY AND MONROE DOCTRINE [124 Polignac as so conclusive as to render unnecessary any declaration by Great Britain and the United States, either singly or jointly, against European intervention in America. But eleven days previous to the date of Canning's letter, President Monroe announced to the world the doctrine that bears his name. 


\section{CHAPTER VI}

\section{The Monroe Doctrine}

Although the South American policy of both the United States and Great Britain aimed to prevent European intervention, the interests and diplomatic relations of the one, and the traditional policy and suspicions ${ }^{1}$ of the other, prevented their governments from engaging in a joint declaration. Separate statement of policy was resorted to in the case of each of these countries. Notwithstanding that fact they were as successful in achieving the immediate purpose common to both as if their opposition to European intervention had taken the form of a joint declaration.

Canning's suggestion for an Anglo-American declaration met with the opposition of the statesmen in the United States whose reverence for the traditional policy of aloofness would not permit their government to engage in any action which might compromise the continuity of that policy. Rush was thoroughly familiar with this attitude among his fellow-statesmen. ${ }^{2}$ The policy of the United States had been one of peaceful relations with all nations, "without offending or forming entangling alliances with any." " Acceding to Canning's propositions would have meant the association of the United States with one of the great powers of Europe against a group of other powers of the same rank. ${ }^{4}$

1 Infra, p. 129.

Rush, op. cit., p. 390 .

3 Ibid., p. 39 I.

I Ibid., p. 390. 
The strongest opponent of the policy of joint declaration was John Quincy Adams, who occupied at the time the very strategic position of Secretary of State. To him a separate declaration of policy by the United States, now that the opposition of Great Britain to European intervention in South America was known, would be fully as effective as a joint Anglo-American declaration. He aimed at the preservation of the traditional policy of the United States, and at the same time at the prevention of European interference.

However, President Monroe wisely sought the counsel of men who could speak from experience gained in his own position: the two ex-Presidents of the United States, Jefferson and Madison. Jefferson replied to President Monroe's request ${ }^{1}$ for his advice:

The question presented by the letters you have sent me, is the most momentous which has ever been offered to my contemplation since that of Independence. That made us a nation, this sets our compass and points the course which we are to steer through the ocean of time opening on us. ... One nation, most of all, could disturb us in our endeavor to make our hemisphere that of freedom; she now offers to lead, aid, and accompany us in it. By acceding to her proposition, we detach her from the bonds, bring her mighty weight into the scale of free government, and emancipate a continent at one stroke, which might otherwise linger long in doubt and difficulty. Great Britain is the nation which can do us the most harm of any one, or all on earth; and with her on our side we need not fear the whole world. With her, then, we should most sedulously cherish a cordial friendship; and nothing could tend more to knit our affections than to be fighting once more, side by side in the same cause. ... With Great Britain withdrawn from their scale and shifted into that of our own

${ }^{2}$ Hamilton (S. M.), The Writings of James Monroe, (New York, I902), vol. vi, pp. 323-325. 
continents, all Europe combined would not undertake such a war. ${ }^{1}$

Madison concurred in the opinion of Jefferson:

It is particularly fortunate that the policy of Great Britain, though guided by calculations different from our's, has presented a cooperation for an object the same with our's. With that cooperation we have nothing to fear from the rest of Europe, and with it the best assurance of success to our laudable views. There ought not, therefore, to be any backwardness, I think, in meeting her in the way she has proposed.'

Two days after sending these views to President Monroe, Madison wrote Jefferson a letter in which he reiterated that, "with the British power and navy combined with our's, we have nothing to fear from the rest of the world. . . . ."

Both these veteran statesmen were convinced of the effectiveness of a joint Anglo-American policy in keeping the European Alliance from intervening in South America. The danger of such intervention to the cause of freedom seemed so real to their minds that they permitted the practical expediency of joint action to overcome their scruples against foreign entanglements. Political considerations made Jefferson to hope that by joining with Great Britain, that country could be permanently won over to the side of liberal institutions. Not only did these statesmen perceive in a joint policy a means of preventing European intervention in South America : they saw in it the opportunity of administering a decisive blow to political despotism in old Europe. ${ }^{3}$

1 Ford, The Writings of Thomas Jefferson, vol. x, pp. 277 et seq., Jefferson to Monroe, 24 October, 1823.

'Hunt (G.), The Writings of James Madison, (New York, 1900-10), vol. ix, pp. 157 et seq., Madison to Monroe, 30 October, 1823.

a Ford, Writings of Thomas Jefferson, vol. $x$, pp. 277 et seq., Jefferson to Monroe, 24 October, 1823. 
However, other circumstances besides those arising out of the policy of the Quadruple Alliance determined the course of the American government. While opposition to the continental policy of intervention afforded a common ground upon which the governments of the United States and Great Britain might have acted in concert, the suspicions which each entertained of the other's desire to acquire additional territory in the western hemisphere was a most powerful factor in determining the government of the United States to act alone. For some time previous to the declaration of the Monroe Doctrine, both England and the United States had manifested their concern for the fate of Cuba. $^{1}$

Early in 1823, Stratford Canning, British Minister at Washington, reported to his chief that the American Cabinet was busy with some new project in the West Indies, that confidential agents had been despatched to Porto Rico, that "the fate of Cuba is still an object of general discussion," that one journalist had published an address to the Cubans with a view to inciting them to an "immediate declaration of independence." 2 The British commander in West Indian waters instructed Captain Bouchier to find out all he could about Key West and its advantage as a naval base in case of war. But he must not, in his attempt to obtain the desired information, arouse the suspicions of the Americans. $^{3}$

President Jefferson, as early as 1808 , expressed his fears lest the ownership of $\mathrm{Cuba}_{\text {| }}$ should be transferred from

${ }^{1}$ Staplaton, Some Correspondence of George Canning, vol. i, p. 52; Latané, op. cit., pp. 84-88.

If. O., America, March-August, 1823, Stratford Canning to George Canning, 9 April, 1823, no. 38 .

'F. O., America, March-August, 1823, Bouchier to Stratford Caming, 19 April, 1823. 
Spain to some other power; and in 1809 he hinted strongly at the possible acquisition of the island by the United States. ${ }^{1}$

It is clear that both the United States and Great Britain realized the strategic importance of the island, and that its possession carried with it the control of the Caribbean and the Gulf of Mexico. Possession of the island by any. strong European power, such as England, would, therefore, place a tremendous obstacle in the way of the southward expansion and the political hegemony of the United States in the New World.

Secretary Adams interpreted the last of Canning's five propositions ${ }^{2}$ as representing the intention of the British government to obtain from the government of the United States a public pledge against seeking to acquire any part of the Spanish-American possessions. ${ }^{3}$ Such a joint selfdenying declaration would have prevented future expansion of the United States through the acquisition of SpanishAmerican territory, except with the consent of Great Britain. The United States would have lost the freedom of individual action. ${ }^{4}$

In respect to Spanish-American territory the aims of the two countries seemed to be mutually exclusive. Accordingly, Adams insisted, not only upon a separate protest by his government against European intervention, but also upon the announcement of a principle aiming to prevent the acquisition of additional American territory by European powers, England included. ${ }^{5}$ The scope of American policy

1 Ford, The Writings of Thomas Jefferson, vol. xi, p. I06, Jefferson to Madison, I9 April, I809.

2 Supra, p. II4.

3 Adams (C. F.), Memoirs of John Quincy Adams, (Philadelphia, I87477), vol. vi, p. I77.

"Temperley, "The Later American Policy of George Canning," American Hist. Rev., vol. xi, p. 797.

- Adams, op. cit., vol. vi, p. 200. 
was thus to be enlarged to include a prohibition against further colonization in the western hemisphere.

The widening of the scope of this policy was influenced by the independent action of the Russian government, as well as by a desire on the part of the American government to exclude the British from the Oregon country. On 4 September, I82I, the Russian Tsar issued a ukase in which he claimed for Russia the northwestern coast of America as far south as the fifty-first parallel, and also prohibited the vessels of foreign powers from approaching within one hundred Italian miles of the territory thus claimed. ${ }^{1}$ These claims were offensive alike to the United States and Great Britain; because both countries had previous claims to a part of the region embraced in the ukase. Some of the places lying within the area claimed by Russia were actually occupied by American and British subjects. ${ }^{2}$ The United States rested its claims upon the Spanish treaty of I8I9 (ratified in I82I) by which Spain ceded to the United States all her rights to the land north of the forty-second degree north latitude, ${ }^{3}$ and upon the rights of discovery and exploration. ${ }^{4}$ Great Britain also based her claims upon the rights of previous discovery and exploration. ${ }^{5}$

By the Anglo-American treaty of $18 \mathrm{r} 8$ the two countries had agreed upon joint occupation of any " country that may be claimed by either party on the northwest coast of

1 U. S., Foreign Relations, (1890), p. 439; F. O., Russia, SeptemberDecember, I82I, Bagot to Londonderry, I7/29 November, I821, no. 56.

2 Hansard, Parl. Debates, (n. s.), vol. ix, p. 387.

${ }^{3} F$. O., Russia, January-December, I823, Bagot to Canning, I7/29 October, I823, no. 48.

4 American State Papers, Foreign Relations, vol. v, p. 446, Adams to Rush, 22 July, I823.

${ }^{5}$ F. O., America, Domestic, Various, September-December, I823, Stratford Canning to George Canning, 24 December, 1823. 
America, westward of the Stony Mountains." 1 Being joint occupants of the territory, part of which was so extravagantly claimed by Russia, both the government of the United States and that of Great Britain protested against the ukase. $^{2}$ The government of Great Britain considered the exclusion of vessels of other powers from within a radius of one hundred Italian miles of the northwest coast as contrary to the law of nations; while Secretary Adams informed Baron de Tuyll, the Russian Minister at Washington, "that we should contest the right of Russia to any. territorial establishment on this continent, and that we should assume distinctly the principle that the American continents are no longer subjects for any new European colonial establishments." 3

Although both of the joint occupants of the Oregon country at first perceived certain advantages in joint negotiations with Russia respecting the northwest claims of the three powers, ${ }^{4}$ and although Secretary Adams sent instructions to Rush and Middleton, the latter being American Minister at St. Petersburg, with that purpose in view, the British government suddenly decided to treat separately with Russia. The government of the United States, therefore, proceeded to negotiate the Russo-American treaty of I7 April, 1824. ${ }^{5}$ By that treaty the United States and Russia agreed upon the line $54^{\circ} 4 \mathrm{o}^{\prime}$ as the boundary between their respective claims on the northwest coast, while Russia at

1 American State Papers, Foreign Relations, vol. v, p. 446, Adams to Rush, 22 July, I823.

Ibid., p. 447.

s Adams, op. cit., vol. vi, p. 163.

4F. O., America, March-August, I823, Stratford Canning to George Canning, 3 May, I823, no. 47; ibid., Russia, January-December, I823, Canning to Bagot, I2 July, I823, no. I2.

- American State Papers, Foreign Relations, vol. v, pp. 432 et seq. 
the same time recognized the three-mile limit of her coastal waters.

Viewed in their relation to the Monroe Doctrine, the two most interesting developments arising out of the Russian claims are: first, the fact that the Russian ukase afforded the government of the United States a stronger ground upon which to base its opposition to further colonization of the American continents by European powers; secondly, the refusal of Canning to enter into joint Anglo-American negotiations with Russia because of the principle which the government of the United States adopted of " not considering the American continents as subjects for future colonization by any of the European powers-a principle to which Great Britain does not accede." 1

On I 5 November, 1823, the government of the United States received from the Tsar a communication in which, as the spokesman of the Quadruple Alliance, he expressed his admiration for the system of government which that Alliance represented, declaring also his intention not to receive representatives from any of the new republics of Latin America. ${ }^{2}$ The document seemed but another challenge of republican institutions by European despotism. It must be answered immediately, lest the Alliance should actually intervene in Latin America, and there should take place the political changes and the transfer of territory which would be so detrimental to the future leadership of the United States in the western hemisphere.

Conditions were now most favorable and most compelling for the announcement of a distinctly American policy. Its announcement at this juncture of the conflicting pur-

1 Ibid., p. 463, Rush to :Middleton, 9 January, I824; cf. Smith, International Lawe, p. 95.

'American Hist. Rev., vol. viii, pp. 30 et seq., Count Nesselrode to Baron Tuyll, 30 August, 1823. 
poses of nations not only afforded the administration the opportunity to make it more comprehensive in its principles, but gave to it a wider application than would have been the case had it been limited to a joint Anglo-American protest, as suggested by Canning, against European intervention in Latin America. The Russian ukase of I82I, the Tsar's communication of 30 August, I823, and the American suspicions of British territorial designs, all combined to influence the administration in its decision to decline joint action with Great Britain, and to enlarge the protest against European intervention so as to include a prohibition of further attempts by European powers to colonize any part of the American continents. ${ }^{1}$

The essential elements of this policy are contained in Adams' reply ${ }^{2}$ to the Tsar's communication of 30 August, I823; but they were publicly declared in the President's Message of 2 December of the same year. In the Message its principles were directed as a protest against the ambitions, political or territorial, of no one power, but of all of them-England included, so far as she aimed at territorial acquisitions.

On 29 November Secretary Adams despatched to Rush the official reply of the United States to Canning's invitation to concert of action. After expressing "an anxious solicitude for the cultivation of that harmony of opinions, and unity of object between the British and American Nations, upon which so much of the Peace, and Happiness, and Liberty of the world obviously depend," Adams replied categorically to Canning's five propositions. ${ }^{3}$ In the first,

1 Ford (W. C.), "John Quincy Adams and the Monroe Doctrine," American Hist. Rev., vol. viii, p. 32.

Ibid., pp. 4I-42.

3 Supra, p. II4. 
Adams naturally concurred. In the case of the second, the United States had already recognized the hopelessness of the recovery of the colonies by Spain and had, therefore, acknowledged them as independent nations. In reply to the third, Adams insisted that the amicable arrangement between the colonies and Spain should be founded on independence, and "provided their accommodation with Spain was founded on that basis," the United States would claim equal favor with the most favored nations politically and commercially in her relations with the Latin-American states. ${ }^{1}$

In reply to the last two of Canning's propositions, Adams set forth the condition on which a joint declaration of policy would be possible:

In both these positions we fully concur-and we add that we could not see with indifference any attempt by one or more powers of Europe, to restore those new states to the crown of Spain, or to deprive them, in any manner whatever, of the freedom and independence which they have acquired. ${ }^{2}$

But a joint declaration of policy with Great Britain was conditioned only upon British recognition of the new republics. $^{3}$

So far Adams had answered Canning's five propositions; and although willing to enter into joint action with Great Britain, provided that the latter would recognize the new states, he feared that in case of an alliance, the United States would become a mere " cock-boat of the British mano'-war." That fear and his patriotic pride, coupled with the strong statesmanlike motive of shaping the course of American policy consistently with the potentialities of his

Imerican Hist. Rev., vol. viii, p. 36.

2 Ibid.

s Ibid. 
growing country, prompted him to advocate separate action unless future circumstances should compel an Anglo-American concert. Hence the tone of the concluding paragraph:

We believe, however, that for the most effectual accomplishment of the object common to both governments, a perfect understanding with regard to it being established between them, it will be most advisable that they should act separately each making such representation to the Continental European Allies or either of them, as circumstances may render proper, and mutually communicating to each other the purport of such representations, and all information respecting the measures and purposes of the Allies ... towards the honourable end which will be common to them both. ${ }^{1}$

The reply to the British government represented a triumph of the conservative policy of avoiding foreign alliances; the Monroe Doctrine as enunciated in the President's Message represented an attitude that was common to both Great Britain and the United States, so far as that attitude was one of opposition to European intervention in South America. But while the Monroe Doctrine represented in part an Anglo-American policy, its prohibition of future colonization on the American continents was distinctly offensive to Great Britain, and made necessary its separate declaration by the government of the United States. On the other hand, had the government of the United States failed entirely to declare its policy, and permitted Great Britain alone to act in seeking to prevent European intervention in South America, it is probable that the gratitude of the new states would have enabled the British to gain a controlling influence over them. ${ }^{2}$ If there were any grounds for such suspicions, it was imperative for the government

1 American Hist. Rev., vol. viii, pp. 37-38.

2 Johnson, America's Foreign Relations, vol. i, p. 344. 
of the United States to declare its policy immediately, though separately.

Secretary Adams had played a clever diplomatic game: he would have an understanding with Great Britain, but he would not make of his country a mere cock-boat to follow in the wake of the British man-o'-war. The result added strength to the position of the United States which was now able to assume a more courageous stand in relation to the European Allies. He felt certain that Great Britain would cooperate without a joint declaration: “. . . . My reliance upon the cooperation of Great Britain rested not upon her principles but upon her interests." 1 England possessed at that time a navy as large as the combined navies of all the other powers of the world ; ${ }^{2}$ and so far as the existence of the British navy compelled respect for those interests, it also compelled respect for, and observance of, the Monroe Doctrine. $^{8}$

It would be a difficult task to measure the relative importance of the motives which actuated Canning in his policy toward South America. They have been variously interpreted. He was undoubtedly possessed of a desire to redress the balance of the old world, to erect a barrier against the ambitious designs of France, to protect British commercial interests in South America, and to oppose consistently the policy of intervention. ${ }^{4}$ Probably, too, he actually sensed a danger to British interests in South America, should the influence of the United States gain the ascendancy among the new republics. ${ }^{5}$ Canning was also inspired by the

1 Adams, Memoirs of John Quincy Adams, vol. vi, p. 203.

2 Hansard, Parl. Debates, (n. s.), vol. x, p. I72.

- Fish, American Diplomacy, p. zir.

"Marriott (J. A. R.), "The Foreign Policy of the United States," Edinburgh Rev., vol. ccxxix, pp. 356-357; Johnson, op. cit., vol. i, p. 336; Moore, Principles of American Diplomacy, p. 240; The Examiner, 28 September and 26 October, I823.

${ }^{5}$ Rush, op. cit., p. 47 I. 
patriotic motive of raising Great Britain to a position of leadership through a course of action independent of, even contrary to, the policy of the continental powers. ${ }^{1}$

But irrespective of the interests of the British people, or the motives and principles of their government, the policy of Great Britain as pursued by her Foreign Secretary harmonized sufficiently with that of the United States to present an effective Anglo-American opposition to European intervention in South America. ${ }^{2}$

The failure of Canning and Rush to reach any agreement looking to concurrent action practically threw Great Britain back upon the letter which Canning had sent to Sir Charles Stuart on 3I March, I823, "as the basis of the policy of England." " The agreement with Prince de Polignac was in essential respects nothing but a restatement of that policy, the only difference being that the letter of 3 I March was a warning, while the agreement with Polignac was an acceptance by France of the attitude of Great Britain as expressed in the letter to Stuart. By that agreement Canning practically forced Prince de Polignac, by threat of war, to "disclaim any idea of French aggression or influence to restore the revolted colonies to Spain." * Canning thereby placed the British navy between France and the Spanish colonies, thus lending force and encouragement to the policy that was shaping in the United States. British interests, for the time being at least, were safe; a

${ }^{1}$ Stapleton, George Canning and His Times, p. 439, Memorandum, 27 April, 1825.

2 Rush, op. cit., p. 467; Henderson, American Diplomatic Questions, p. 316.

${ }^{3}$ Rush, op. cit., p. $4 \mathrm{r} 2$.

- Temperley (H. W. V.), "Later American Policy of George Canning," American Hist. Rev., vol. xi, p. 779; supra, p. 69.

${ }^{5}$ Rush, op. cit., pp. 416-417. 
substitute had been found for the proposed Anglo-American declaration. The harmony of the South American policies of the two English-speaking countries appeared so plain to European statesmen that they were inclined to regard the Monroe Doctrine as an endorsement of British policy. ${ }^{1}$

In his report of the contents of the Canning-Polignac note, Rush commented significantly upon the results of the conclusions at which these two statesmen had arrived: "The apprehensions of Britain, however, seem to be fully allayed, at least for the present; and it is certain that she does not now anticipate any speedy interruption of the peace of Europe from this cause." ${ }^{2}$

The principles of the Monroe Doctrine had not yet been formulated when the Canning-Polignac conference took place. Indeed, whether or not there was to be a Monroe Doctrine seems to have depended largely upon the outcome of that conference. But the firm attitude of Great Britain, coupled with the fact that the United States must have been considered at least as a potential supporter of England's policy, was sufficient reason for France to modify her attitude. Considerations of that nature weighed heavily in favor of Great Britain at the time of the conference. The very character and political sympathies of the United States were consequently a powerful asset favorable to the success of British diplomacy in the attempt to check French aggression in Spanish America. Canning, having become familiar with the position of the United States, felt that he could safely depend upon the support of this country should France become stubborn and defiant-the failure of his plan for a joint declaration notwithstanding. $\mathrm{He}$ was also conscious of the powerful impetus which his

1 Temperley, "Later American Policy of George Canning," American Hist. Rev., vol. xi, p. 779.

${ }^{2}$ Rush, op. cit., p. 414; cf. Annual Register, vol. 1xv, pp. 164-165. 
overture to Rush gave to American policy, ${ }^{1}$ in which he saw a source of strength that would assure the success of his own: ". . . . I have no doubt that his [Rush's] report to his government of this sounding (which he probably represented as an overture) had a great share in producing the explicit declarations of the President." 2

The governments of the United States and Great Britain had become familiar with one another's attitude on the South American question through the Canning-Rush correspondence and interviews. ${ }^{3}$ The result was a feeling of confidence in one another's support. Just as Canning's position in his conference with Prince de Polignac was strengthened by his knowledge of the attitude of the United States, so the knowledge of Canning's attitude encouraged the government of the United States to declare its policy in a firm and decisive tone. ${ }^{4}$ Sir James Mackintosh asserted in Parliament that President Monroe's Message was influenced by the British communications. ${ }^{5}$ Rush himself agreed essentially with that opinion:

Although, in the end, no concerted movement took place between the two governments, the communications to me, from the Secretary of State, in responding to the overtures of $\mathrm{Mr}$. Canning, were in a high degree conciliatory towards England; and framed with every just sensibility to the frank and friendly spirit of those overtures. ${ }^{6}$... My despatches had distinctly

1 Stapleton, George Canning and His Times, p. 395, Canning to William à Court, 3I December, I823.

2 Ibid.

S Stapleton, Life of Canning, vol. ii, p. 39.

4 Ibid., pp. 39, 46; Rush, op. cit., p. 420; Bryce (J.), "British Feeling on the Venezuelan Question," North Am. Rev., vol. clxii, p. I47.

"Stapleton, Life of Canning, vol. ii, p. 39.

6 Rush, op. cit., pp. 417-418. 
put before our government the intentions of England, with which, in the main, our policy harmonized. ${ }^{1}$

For various reasons, then, Canning, though no outspoken advocate of liberal forms of government, found himself by coincidence of economic interest, a champion of liberalism in $1823 .^{2}$ That he was guilty of exaggeration when he asserted in I 826 that he had "called the new world into existence to redress the balance of the old " cannot be denied. His chief contribution to the pronouncement of the Monroe Doctrine is to be found in the policy of his office in dealing with the Alliance, France, Spain and the South American states; the international situation which that policy created; the encouragement which he gave to the government of the United States through a frank expression of his own attitude and that of his country; ${ }^{3}$ above all, in his desire to satisfy the commercial interests of England, and his determination to use force to do so, if necessary; and in his warning of the danger that was threatening American liberties from the plans of the continental powers."

Thus, the British policy as represented by Canning, and the American policy as represented by President Monroe, derived their effectiveness from the fact that they rested upon a common understanding, and consequently upon the faith of ultimate unity of action. ${ }^{5}$

The proposed Congress of Paris, ${ }^{6}$ of which Canning had

1 Rush, op. cit., p. $4 \mathrm{I} 8$.

2 Beaumarchais (M. P. J. D.), La Doctrine de Monrö̈, (Paris, I898), p. 6; Rush, op. cit., p. 467 .

3 Tower, op. cit., p. 20.

'Johnson, op. cit., vol. i, p. 348; Henderson, op. cit., p. 316; McLaughlin, America and Britain, pp. II9-I20.

${ }^{5}$ Rush, op. cit., p. 420.

- $F$. O., South America, 1822-1823, Communications with France and Spain Relating to the Spanish-American Provinces, no. 2. 
warned Rush, failed to assemble. ${ }^{1}$ The purpose of that congress was to discuss the affairs of South America; but the attitude of Great Britain and the United States convinced the continental statesmen of its utter futility. ${ }^{2}$ Great Britain declined the invitation to be represented. ${ }^{3}$ In his reply to Count Ofalia, Canning stated that Great Britain's opposition to intervention in South America by any European power, except Spain, could not be changed. It was a position which Great Britain had maintained consistently since the Congress of Aix-la-Chapelle, and from which no congress of powers could move her. He, therefore, considered the congress proposed by the Spanish government rather as a possible source of delay than as an aid in the solution of the Spanish-American question." The United States refused to "sanction by our presence any meeting of European Potentates to dispose of American Republics." 5

In reference to representation at this congress of powers, Canning had already (I8 September) stated to Rush that should he [Rush] be invited to attend the congress, and then decline the invitation, Canning would reserve the right, should he be invited, also of staying away from the meet-

1 Stapleton, Life of Canning, vol. ii, p. 39; Ford, John Quincy Adams, his Connection with the Monroe Doctrine, p. 49, Canning to Rush, 23 August, 1823; F. O., South America, 1822-1823, Communications with France and Spain Relating to the Spanish-American Provinces, no. 2; Temperley, George Canning, p. 180.

Stapleton, Life of Canning, vol. ii, p. 39.

IIbid., pp. 36, 38, 40-41 ; F. O., South America, Communications with France and Spain, Canning to William à Court, 30 December, I823.

4 Ibid., no. 3, Canning to William à Court, 30 January, I824; cf. ibid., France, May-December, 1823, Canning to Stuart, 9 November, I823, no. 84 .

- Ford, John Quincy Adams, etc., p. 23, Adams to Rush, November 30, 1823. 
ing. ${ }^{1}$ Nothing could point more plainly to the perfect sincerity of Canning in a strong effort to identify the policy. of his country with that of the United States. By staying away from the congress if the American representative did, he would impress the other European statesmen with the fact that England and the United States were in accord respecting the Spanish-American question.

Without the cooperation of England the Monroe Doctrine would have been little short of useless as a preventive of European intervention. The allied governments had shown little or no regard for the attitude of the United States in formulating their Spanish-American policy. ${ }^{2}$ They showed as little respect for that attitude when given formal expression by President Monroe. ${ }^{3}$ Even after President Monroe's Message had reached the European capitals, the allied powers tried to induce the government of England to cooperate with them in the settlement of the SpanishAmerican question. ${ }^{4}$ The refusal of England to join with them in a new congress deprived them of the support of the one state necessary for the success of their plan. Nesselrode, Russian secretary of foreign affairs, readily admitted that with England in opposition, the failure of the allied plan of intervention in Spanish America was a foregone conclusion: "Though the Allies, by a strict interpretation of their doctrines, might be bound not to refuse a direct assistance in men and ships to Spain, that power will readily see that so rigid a construction of their engagements will serve no useful purpose while England maintains its present

1 Rush, op. cit., p. 395.

2 British and Foreign State Papers, vol. xi, p. 49; F. O., France, vol. 295, no. 557; Chateaubriand, Congress of Verona, vol. ii, p. 282; Perkins, Am. Hist. Rev., vol. xxvii, pp. 21I-2I3.

${ }^{3}$ F. O., Austria, vol. 182, no. 16; ibid., France, vol. 305, desp. 8.

4 Perkins, Am. Hist. Rev., vol. xxvii, p. 215. 
attitude;" "1 and Chateaubriand was determined " not to risk a rupture with the Cabinet of St. James on this colonial question." 2 Not the United States, but England, was the real barrier to allied intervention in Spanish America. Her possession of the largest navy in the world gave practical effectiveness to her own opposition as expressed in the Canning-Polignac agreement, as well as to that of the United States as expressed in the Monroe Doctrine.

Now, suppose, on the contrary, that the interests of Great Britain had been of a nature to identify her policy with that of the continental powers, no stretch of the imagination is necessary to conceive of the consequences. ${ }^{3}$ The new states of South America would have been destroyed, and probably the southern continent would have been parcelled out among its conquerors, ${ }^{4}$ against which an independent protest by the United States would have been conspicuously ineffective. $^{5}$ It is greatly to the credit of Secretary Adams that American liberties, for the preservation of which Jefferson and Madison had advised concurrent action, were protected through Anglo-American cooperation without entering into any entangling alliances. ${ }^{6}$

To the extent that the Monroe Doctrine constituted a reenforcement of British policy it was well received in Great Britain; while its prohibition against European colbnization not only failed of immediate recognition, but met with severe criticism. $^{7}$ In prohibiting European colonization on the

2 Quoted by Perkins, Am. Hist. Rev., vol. xxvii, p. 215.

3 Chateaubriand, op. cit., vol. ii, p. 304.

3 The London Times, 22 November, 1906.

4 Kraus (H.), "What the European Countries Think of the Monroe Doctrine," Annals of the Am. Acad. of Pol. and Soc. Science, vol. liv, p. 107.

- Henderson, American Diplomatic Questions, pp. 321, 340.

- Reddaway, The Monroe Doctrine, pp. 96, 98.

7 Stapleton, Some Correspondence of George Canning, vol. ii, pp. 79-80, Canning to the British Commissioners, 3I May, I824; Annual Reg., vol. $1 x v$, p. 239. 
American continents, the Monroe Doctrine went far beyond Canning's expectations; and it has been that part of the Monroe Doctrine over which Anglo-American relations have occasionally become much disturbed. But circumstances of American expansion have served to reduce the chances of renewed antagonism on account of that principle. The political principle of the Monroe Doctrine has not been seriously questioned by Great Britain. ${ }^{1}$ It was to that principle that Canning referred when he said that " the SpanishAmerican question is, essentially, settled. There will be no Congress upon it; and things will take their own course on the continent, which cannot be otherwise but favorable to us." 2 The same opinion was expressed by other British' statesmen who saw in the political principle of the Monroe Doctrine the hope of Anglo-American cooperation in the future. Said Lord Brougham, a member of Parliament:

The question in regard to Spanish America is now, I believe, disposed of, or nearly so; for an event has happened than which none has ever dispersed greater joy, exultation, and gratitude over all the freemen of Europe: that event which is decisive on the subject is the language held with respect to Spanish America in the Message of the President of the United States. ${ }^{3}$

Sir James Mackintosh, another member of Parliament, delighted in contemplating the two great English commonwealths uniting their forces in the interest of justice and liberty. ${ }^{4}$

The official opinion of British statesmen was echoed in

1 Johnson, America's Foreign Relations, vol. i, p. 349.

2 Stapleton, George Canning and His Times, p. 394, Canning to William à Court, 3r iDecember, 1823.

3 Parliamentary Papers, (188z), vol. 1xxx, p. 88, quoted by Frelinghuysen to Lowell, 8 May, I882.

Ibid. 
the public press, in which the President's Message was considered as "plain speaking and just thinking." ${ }^{1}$ The British press was almost unanimous in its enthusiastic welcome of the Monroe Message. ${ }^{2}$ It was an additional evidence of the harmony of British and American policies relative to South America:

With what satisfaction ... must we receive the tidings, when they announce the intended prosecution of a policy so directly British? From the similarity of the position occupied by Great Britain and the United States, in reference to what was Spanish America, it is difficult to calculate on any but an identity of measures, and an equal hostility to the machinations of the Holy Alliance. ${ }^{3}$

Similar expressions of approval of the Message were many. It was considered as a decisive force in the settlement of the most important of the political questions then pending, ${ }^{4}$ and as an effective instrument in placing South America beyond the grasp of the Alliance. ${ }^{5}$ But recognition of the part played by the British government was not lacking: "The project of reuniting South America to Spain has been defeated by the decided tone of the President of the United States, and the no less manly, though more temperate and cautious, proceedings of our Ministers." ' It was recognized that no expedition by the members of the Alliance could possibly be hazarded in the face of the resistance both

1 The London Times, 27 December, 1823.

2 Ibid., 6 January, 1824 .

3 Ibid., 6 January, I824.

- Bell's Weckly Register, 28 December, 1823.

5 The Examiner, 28 December, .1823; The Morning Post, 27 December, 1823.

- Bell's Weekly Register, zو February, I824. 
of Great Britain and of the United States. ${ }^{1} \quad$ That the British public felt confident that the Spanish-American problem had been definitely settled was evidenced by the immediate rise of Spanish-American securities. ${ }^{2}$

Though the Monroe Doctrine derived most of its effectiveness from its relation to British Policy, its promulgation in 1823 as the policy of the United States marks the end of one period and the beginning of another in the history of America. It was a public announcement that the states of the western hemisphere, where Europeans had long and greedily rivalled one another for supremacy, had reached a stage in their development where such rivalry must cease, and their political maturity and right to independence must be recognized on the basis of equality with the states of the Old World. For the United States it marks, more particularly, the rise of its political primacy among the republics of America, a position by which it has often reduced the chances of war in the New World, and contributed as well to the maintenance of peaceful relations between the two hemispheres.

${ }^{1}$ The Examiner, 25 January, I824; Cobbett's Pol. Reg., vol. xlix, p. I4.

2 Reddaway, op. cit., pp. 94-95. 


\section{BIBLIOGRAPHY}

\section{SOURCES}

Adams (J. Q.), Memoirs of John Quincy Adams (ed. by C. F. Adams), I2 volumes, Philadelphia, I874-1877.

- Writings (ed. by W. C. Ford), I2 volumes, New York, I9I3-I9I7. American State Papers, Foreign Relations, 6 volumes, Washington, 1833-1859.

Annals of Congress: Debates and Proceedings in Congress, Washington, $1834-1856$.

Annual Register, I04 volumes, London, I762-1863.

British and Foreign State Papers, London, I84I-

Canning (George), Memoirs (ed. by John Styles), 2 volumes, London, 1828.

- Speeches (ed. by R. Therry), 6 volumes, London, I828.

Castlereagh (Robert Stewart, Lord Castlereagh, 2nd Marquess of Londonderry), Correspondence, I2 volumes, London, 1853 .

Ford (W. C.), John Quincy Adams, his connection with the Monroe Doctrine (1823), Cambridge, 1902.

Hall (Basil), Extracts from a Journal zeritten on the coasts of Chili, Peru, and Mexico in the years I820, I821, I822, Philadelphia, I824.

Hertslet (Edward), The Map of Europe by Treaty, 4 volumes, London, 1875-1891.

Jefferson (Thomas), Works (ed. by P. L. Ford), 12 volumes, New York, 1904.

Madison (James), Writings (ed. by G. Hunt), 9 volumes, New York, 1900-1910.

Marshall (J.), A Digest of all the accounts diffused through more than 600 volumes of Journals, Reports, and Papers presented to Parliament since 1799, London, 1833 .

Monroe (James), Writings (ed. by S. M. Hamilton), 8 volumes, New York, 1902.

Parliamentary Debates (ed. by T. C. Hansard), London, i812-

Parliamentary Papers, London, I8oI-

Public Record Office, London,

Forcign Office Records-America, South America, Continent, Austria, France, Russia and Spain.

Richardson (J. D.), Messages and Papers of the Presidents, to volumes, Washington, $1896-1899$. 
Rush (Richard'), The Court of London from 1819 to 1825 , London, 1873. Stapleton (E. J.), Some Official Correspondence of George Canning, 2 volumes, London, I887.

Washington (George), Writings (ed. by Jared Sparks), 12 volumes, Boston, 1839 .

Wellington (Arthur Wellesley, Duke of Wellington), Supplementary Despatches, 15 volumes, London, 1858-1872.

\section{Secondary Works}

Abbott (W. C.), The Expansion of Europe, including Asia, Africa, and Latin America, 2 volumes, New York, I9I8.

Adams (Henry), History of the United States of America, 9 volumes, New York, I89I.

Beaumarchais (M. P. J. D.), La Doctrine de Monrö̈, Paris, I8g8.

Beer (G. L.), The English-Speaking Peoples; their future relations and joint international obligations, New York, I918.

Bigelow (John), American Policy: the western hemisphere in its relation to the eastern, New York, 1914.

Bogart (E. L.), The Economic History of the United States, New York, IgI3.

Broderick (G. C.) and Fotheringham (J. K.), A History of England, I80I-1837, London, 1906.

Cambridge Modern History, I2 volumes, New York, I902-I9I0.

Channing (Edward), A History of the United States, 5 volumes, New York, I912-

Chapman (IC. E.), A History of Spain, New York, 1918.

Chateaubriand (M. de), The Congress of Verona, 2 volumes, London, 1838 .

Cheyney (E. P.), Industrial and Social History of England, New York, I920.

Cunningham (William), The Growth of English Industry and Commerce in Modern Times, Cambridge, 1892.

Day (Clive), $A$ History of Commerce, New York, IgI7.

Dewey (D. R.), Financial History of the United States, New York, 1903.

Dunning (W. A.), The British Empire and the United States, New York, I9I4.

Everett (E.), The Monroe Doctrine, New York, 1863.

Fish (C. R.), American Diplomacy, New York, Igr6.

Foster (J. W.), A Century of American Diplomacy, Boston, Igor.

Hart (A. B.), The Foundations of American Foreign Policy, NeN York, Igor.

- The Monroe Doctrine, Boston, 1915.

Hassall (Arthur), Viscount Castlereagh, London, 1908. 
Hayes (C. J. H.), A Political and Social History of Modern Europe, 2 volumes, New York, IgI6.

Henderson (J. B.), American Diplomatic Questions, New York, IgoI.

Hill (D. J.), A History of European Diplomacy, 3 volumes, New York, I9I4.

Johnson (W. F.), America's Foreign Relations, 2 volumes, New York, I916.

Kasson (J. A.), The Evolution of the Constitution of the United States of America and History of the Monroe Doctrine, Boston, IgI4.

Kraus (H.), Die Monroedoktrin in ihren Beziehungen zur Amerikanischen Diplomatie und zum Volkerrecht, Berlin, 1913.

Latané (J. H.), The United States and Latin America, Garden City, 1920. Levi (Leone), History of Commerce, London, I880.

Lipson (Ephraim), An Introduction to the Economic History of England, London, I920.

MoLaughlin (A. C.), America and Britain, New York, I9I9.

McMaster (J. B.), A History of the People of the United States, 7 volumes, New York, I885-1910.

Mahan (A. T.), The Influence of Sea-Power upon History, Boston, I893. Marriott (J. A. R.), George Canning and His Times, London, 1903.

Moore (J. B.), The Principles of American Diplomacy, New York, IgI8. Ogg (F. A.), The Economic Development of Modern Europe, New York, 1917.

Page (William), Commerce and Industry: A Historical Review of the Economic Conditions of the British Empire from the Peace of Paris in I8I5 to the Declaration of War in I9I4, based on Parliamentary Debates, London, I9I9.

Paxson (Frederic L.), The Independence of the South American Republics, Philadelphia, I9I6.

Phillips (W. A.), The Confederation of Europe, New York, I9I4.

Porter (G. R.), The Progress of the Nation, 3 volumes, London, I838.

Reddaway (W. F.), The Monroe Doctrine, New York, 1905.

Schurz (Carl), Henry Clay, Boston, I887.

Semple (E. C.), Influence of Geographic Environment, New York, IgII. Shepherd (W. R.), The Hispanic Nations of the New World, New Haven, 1920.

Smith (Frederick), International Laze, London, I9I8.

Snow (Freeman), Treaties and Topics in American Diplomacy, Boston, 1894 .

Stapleton (A. G.), George Canning and His Times, London, 1859.

- The Political Life of the Right Honourable George Canning, 3 volumes, London, 1831 .

Temperley (H. W. V.), George Canning, London, 1905.

Tower (Charlemagne), Essays, Political and Historical, Philadelphia, 1914. 
Turner (F. J.), Rise of the New West, I819-1829, New York, I906.

Villèle (Comte de), Memoires et Correspondence, 4 volumes, Paris, I888-1890.

Walpole (Spencer), History of England, 6 volumes, London, 1890.

Wilson (G. G.) and Tucker (G. F.), International Law, Boston, 19I5.

Woolsey (T. S.), America's Foreign Policy, Essays and Addresses, New York, 1898 .

\section{ReVIews aNd NewSPapers}

The American Historical Review, volumes, vii, viii, ix and xxvii.

The Annals of the American Academy of Political and Social Science, volume liv.

Edinburgh Review, volume ccxxix.

North American Review, volumes clxii and clxxvi.

Bell's Weekly Messenger.

Cobbett's Political Register.

The Examiner.

The London Times.

The Morning Chronicle.

The Morning Post. 


\section{INDEX}

Adams, John, 20; Message of I797, 20

Adams, John Quincy, on Canning's propositions, I29; reply to Rush, I33-I35 ; significance of his diplomacy, 136

Aix-la-Chapelle, Congress of, 36

Alexander, Tsar of Russia, 33; Memorandum, 37; plan for European peace, 37-39; proposes Holy Alliance, 32

Allies, policy of intervention, I4; notes to Madrid, $55-56$; recall of Ministers, 56

American colonies, I2

American policy, scope of, I29I33; in Monroe Doctrine, I33

American System, 28

Amiens, peace of, 77

Anglo-American cooperation, I3, I5; conditions favoring, I5; sought, $26-27,32$, IOO-II2, II7; obstacles, Io9-II9; Canning's arguments, II7-II8

Anglo-French rivalry, 57, II-I4, $89-90,92$

Argentine Confederation, 22

Asiento, 81

Austria, intervention in Naples and Piedmont, 46

Balance of power, 66

Bathurst, 38 ; on intervention, 38

Bell's Weekly Register, 87; on economic motives, 94

Bolivia, 22

Bouchier, I28

Bourbon monarchies, 58

British government, friendly feeling of, 108-109

British policy, 76 ; economic basis, $77,80,82-100$, I02-IO3; means, IO3; compared with that of the U. S., II9

Buenos Ayres, 22

Canada, I6

I5I]
Canning, George, I5; opposed to congresses, 40, 5I; Sec. of For. Affairs, 46-47; foreign policy, $5 \mathrm{I}-52$; political principles, $52-53$, 63,68 ; on Congress of Verona, 59 ; on King's speech, 60-6r ; efforts to maintain peace, 62 ; Memorandum, 69; opposed to intervention in South America, 69-70; letter to Stuart, 76, I I0; Cabinet Circular, I04; on AngloAmerican relations, Io8-rog; interviews with Rush, IO9-II2; on recognition, II3 ; propositions to Rush, II4; warning of new congress, II5; conference with Polignac, I2I-I24; motives, I36I37; American influence, I38; on Congress of Paris, I4I-I42

Canning, Stratford, I28

Canning - Polignac agreement, Memorandum of, I2I; reasons for, I22 ; terms, I22-I23; significance of, I23-I24; substitute for joint declaration, I37-I 38 ; comment of Rush, I38; relation to Monroe Doctrine, I 38

Castlereagh, 35; at Aix-la-Chapelle, 37; on treaties of Paris and Vienna, 38 ; opposed to intervention, 43 ; on Troppau Protocol, 45; Memorandum, 47 ; instructions on South America, 82

Chateaubriand, $6 \mathrm{I}$; on intervention in Spain, 6I-62; justification of war, $64-65$; on Family Compact, 67 ; fear of British naval power, I43

Chaumont, treaty of, 35, 38-39

Chile, 22

Clay, 27; on recognition of LatinAmerican republics, 27-28; and American System, 28 
Cobbett's Political Register, criticism of merchants, 95

Colombia, 22

Common Council, 74

Congress (United States), resolution, 24 ; acts of neutrality, 25; on recognition, 28

Constitutionalists, 54 ; conduct of, 64

Consuls, 105

Cuba, I28

Declaration, Anglo-American, IIII12, II 5 ; obstacles, 109, I19, I24; dependent on recognition, II9; and Canning-Polignac agreement, I24; opposed in the U. S., I25-126; attitude of Jefferson and Madison, I26-127

Embargo, 78

England, foreign policy, II ; relations with France, II,.I2; effects of Industrial Revolution, 13; commercial interest, 12 ; industry, I3; exports, I3; colonial trade, I4; opposed to intervention, I4, 38-40, 43, 46; maritime power, 15 ; public opinion on intervention, 6I ; neutrality, 66-68, 70 ; neutrality limited, 69-7I; break with Alliance, 48 ; commercial agents, 95 ; naval power, I43; views on Monroe Doctrine, I 43-I 46

Exports, British, to continent, 7778 ; to the U. S., 78-79; to South America, 83-86

Family Compact, 67

Ferdinand VII, 46,48 ; restored, 75

Florida treaty, 26; ratified, 28; provisions of, I30

France, exports of, 14; trade with continent. I4: policy, 54-60; war with Spain, 64

General Alliance, 37

Geography, influence of, 15-16

Great Britain (see England)

Grey, 66

Hobhouse, 66

Holy Alliance, Io; origin of, 32 ; and England, 33; purpose, 3334 ; danger of, 34; hymn to, 74

Intervention, in Latin America, 9; danger of, 9; opposed by England, I4, 28; relation to Monroe
Doctrine, 18; doctrine of, 28, 44 ; in Spain, $54,65,72-73$

Interviews, Canning-Rush, rogII2; sudden termination of, I2O Isolation, policy of, I8-2I ; relation to Napoleonic wars, 2I

Jefferson, 20; policy of isolation, 20; First Inaugural Address, 21; advice to Monroe, 126-127; on Cuba, 128

Laibach, Congress of, 60 ; declaration of, 60

Latin America, independence of, 22 (see Spanish colonies)

Legitimacy, 56

Legitimists, 58

Liverpool, Io9

Loans, 94

"Lord Colingwood," 96

London, Lord Mayor of, 74

London Times, anticipates Monroe Doctrine, 93

Louis XVIII, 56 ; speech of, $59-60$ Mackintosh, I39

Madison, Message of I8II, 23-24; proclamation of neutrality, 25 ; advice to Monroe, 127

Mediation, 54; declined, 55

Metternich, 28

Mexico, 22

Middleton, $13 \mathrm{I}$

Monroe, 28; recommends recognition, 28; Message, I33, I42

Monroe Doctrine, in foreign relations, 9; relation to British policy, Io; roots of, I8; as policy of isolation, 18; and transfer of territory, 22; principles of, 93 ; editorial comment upon, I08; scope of, I33-I34; British influence, I39-140, I42; British attitude, I35, I43-146; effects of, 146

Montmorency, 55

Naples, revolution in, 40; Austrian intervention, 46

Napoleonic wars, effects of, 86

Non-Intercourse Act, 78

Non-intervention, British policy of, 29; relation to Monroe Doctrine, 29; source of, 49-50

Northwest claims, I30-132

Orders in Council, 78

Oregon, I3I

Paine, 2I 
Paraguy, 22

Paris, Congress of, 35 ; failed to meet, I4O-I4I ; purpose, I4I ; views of Canning, I4I-I42

Paris, treaty of (I763), I2; (I815), 39

Parliament, committee of, 87

Peru, 22

Petitions, 86-89

Piedmont, revolution, 40

Polignac, conference with Canning, I2I-I 24

Porto Bello, 8I

Portugal, revolution, 4I ; Austrian intervention, 46 ; treaty, 66

Propositions relative to South America, Canning's, II4; sent by Rush, II5 ; reply of Rush, II5II6, II9; views of Rush, II9; views of Adams, I29

Public opinion, British, $6 \mathrm{r}$; on intervention in Spain, 66, 72-74

Quadruple Alliance, Io; policy of, I4; treaty of, 35,46 ; views of Castlereagh, 35; treaty modified, 35-36; purpose, $37-38$; authority limited, $39-40$; Congress of Troppau, 43; intervenes, 48 ; withdrawal of England, 48; plans reduced to Anglo-French rivalry, 59

Quintuple Alliance, Io

Recognition of South American republics, question of, I04-I08; attitude of England, IOO-IO2; advocated by Rush, II2-II3, I2O; obstacles, II9-I2I ; Canning's refusal, I2I

Republicanism, relation to recognition, 23, 27-28, 72, I2I

Republics of South America, I00108

Revolution, American, 16; attitude of English, 16; French, 13, 30; Industrial, 12, 13, 30

Rush, I02; on British motives, I02-IO3; despatch to Monroe, I09; interviews with Canning, IO9-II2; insists upon recognition, II2-II3, I19; warned of new congress, II 5 ; reply to Canning, I15-116; report of interviews, I20; on Canning-Polignac conference, 138

Russian circular, $4 \mathrm{I}$; contents of,
4I-42; British attitude, 42; Northwest claims, I30

Russo-American treaty (I824), I3I-I32

Sea power, British, 14, 143; and trade, I3-I 4

Shipping, British, attacks upon, 96-98

South-American question, solution of, I03; new congress on, II 5

Spain, revolution, 40, 46; allied intervention, 46, 48, 5I-76; British interest, 48; colonial trade, $8 \mathrm{r}$; trade agreements, $82-83$

Spanish colonies, revolt of, 22 ; recognition of, $7 \mathrm{I}$; recognition withheld by England, 72; British interest, 80,92 ; commercial agents, 95

Spanish Succession, War of, I I

Stewart, 43

Stuart, 69 ; Canning's letter to, 76, IIO, I37

Subscription, public, 74

Territory, American, transfer of, 2I ; Madison's recommendation, 122

Trade, British, with South America, $83-86$

Troppau, Congress of, 4I, 43; Protocol of, 44; British attitude, 45

Tuyil, I3I

Ukase, Russian, I30

United States, independence and foreign policy of, I3: British background, I6; Latin-American policy of, 23-24, 29; opposed to alliances, I7-18; policy of isolation, 18, 20-21 ; considered as rival, 98-100; favors separate declaration, 128

Utrecht, treaty of, II

Verona, Congress of, 47; British triumph, 53-54 ; Canning's comment, 59 ; British commercial interest, 82-83

Vienna, Congress of, 30 ; purpose, $3 \mathrm{I}$ : treaties of, $3 \mathrm{I}$

Villèle, 55; policy toward Spain, $55,63-64$

Washington, advice of, I9; neutrality proclamation, i9

Wellington, at Congress of Verona, 47 ; withdrawal, 48 



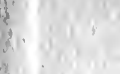







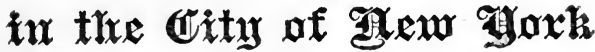

The University includes the following :

Columbia College, founded in 1754, and Barnard College, founded in 1889 , offering to men and women, respectively, programs of study which may be begun either in September or February and which lead normally in from three to four years to the degree of Bachelor of Arts. The program of study in Columbia College makes it possible for a well qualified student to satisfy the requirements for both the bachelor's degree and a professional degree in law, medicine, technology or education in five to seven years according to the conrse.

The Faculties of Political Science, Philosophy and Pure Science, offering advanced programs of study and investigation leading to the degrees of Master of A rts and Doctor of Philosophy.

The Professional Schools of

Law, established in 1858, offering courses of three years leading to the degree of Bachelor of Laws and of one year leading to the degree of Master of Laws.

Medicine. The College of Physicians and Surgeons, established in 1807, offering two-year courses leading to the degree of Bachelor of Science and fouryear courses leading to the degree of Doctor of Medicine.

Mines, founded in 1863 , offering courses of three years leading to the degrees of Engineer of Mines and of 1 fetallurgical Engineer.

Chemistry and Engineering, set apart from School of Mines in 1896, offering three-year courses leading to degrees in Civil, Electrical, Mechanical and Chemical Engineering.

Teachers College, founded in 1S88, offering in its School of Education courses in the history and philosophy of education and the theory and practice of teaching, leading to appropriate diplomas and the degree of Bachelor of Science in Education; and in its School of Practical Arts founded in 1912, courses in household and industrial arts, fine arts, music, and physical training leading to the degree of Bachelor of Science in Practical Arts. All the courses in Teachers College are open to men and women. These faculties offer courses leading to the degree of Master of Arts and Master of Science.

Architecture, offering a program of indeterminate length leading to the degree of Bachelor of Architecture and Master of Science.

Journalism, founded in 1912, offering a two-year course leading to the degree of Bachelor of Literature in Journalism. The regular requirement for admission to this course is two years of college work.

Business, founded in 1916, offering two and three-year courses in business training leading to appropriate degrees.

Dentistry, founded in 1917, offering four-year courses leading to appropriate degrees.

Pharmacy. The New York College of Pharmacy, founded in 1831, offering courses of two, three and four years leading to appropriate certificates and degrees.

In the Summer Session the University offers courses giving both general and professional training which may be taken either with or without regard to an academic degree or diploma.

Through its system of University Extension the University offers many courses of study to persons unable otherwise to receive academic training.

The Institute of Arts and Sciences provides lectures, concerts, readings and recitals-approximately two hundred and fifty in number-in a single season.

The price of the University Catalogue is twenty-five cents postpaid. Detailed information regarding the work in any department will be furnished without charge upon application to the Secretury of Columbia University, New York, N. Y. 


\section{Published May 1, 1922}

\section{China at the Conference}

BY

\section{W. W. WILLOUGHBY}

Professor of Political Science at The Johns Hopkins University

Octavo. 435 pages. Price $\$ 3.00$

This volume, in the form of a semi-official report, will take its place along side the author's well-known work "Foreign Rights and Interests in China," and will give the reader an accurate statement of the results of the recent Conference at Washington.

Besides chapters explaining the reasons for the discussion by the Powers of the political and international situation in the Far East, describing the organization and procedure of the Conference; and estimating its results, there are chapters dealing severally with each of the important subjects discussed in the Conference and regarding which Treaties or Resolutions were adopted. In an Appendix the texts are given of these important documents.

Inasmuch as, with the exception of a part of a single session which was devoted to the situation in Siberia, the entire work of the Conference so far as it dealt with political questions in the Pacific and Far East, was concerned with the affairs of China, the present volume gives, in effect, a comprehensive account of the work of that Conference. In order that it may be quite complete in this respect there is given in the Appendix the statements made-there were no discussions-with reference to the Siberian situation.

\section{The Johns Hopkins Press}

Baltimore, Maryland, U. S. A. 


\section{Columbia University Press Publications}

CONSTITUTIONAL GOVERNMENT IN THE UNITED STATES. By Woodrow Wilson, LL.D., President of the United States. Pp. vii +236. OUR CHIEF MAGISTRATE AND HIS POWERS. By William Howard TAFT, Twenty-seventh President of the United States. Pp. vii +165 .

CONSTITUTIONAL POWER AND WORLD AFFAIRS. By GEORGE SUTHERLAND, former United States Senator from Utah. Pp. vii +202.

WORLD ORGANIZATION AS AFFECTED BY THE NATURE OF THE MODERN STATE. By DAVID JAYNe Hill, LL. D., late American Ambassador to Germany. Pp. ix +214. Reprinted with new Preface.

THE BUSINESS OF CONGRESS. By SAMUel W. MCCall, Governor of Massachusetts. Pp. vii + 2 I5.

THE COST OF OUR NATIONAL GOVERNMENT. By HENRY JONES FORD, Professor of Politics in Princeton University. Pp. xv +147.

POLITICAL PROBLEMS OF AMERICAN DEVELOPMENT. By AlberT Shaw, LL.D., Editor of the Review of Reviezes. Pp. vii +268.

THE PRINCIPLES OF POLITICS FROM THE VIEWPOINT OF THE american Citizen. By Jeremiah W. Jenks, LL.D., Professor of Government and Public Administration in New York University. Pp. xviii +187 .

The NATURE AND SOURCES OF THE LAW. By JoHN Chipman Gray, LL.D., late Royall Professor of Law in Harvard University. Pp. xii + 332.

THE GENIUS OF THE COMMON LAW. By the Right Honorable Sir FredERICK Pollock, Bart., D.C.L., LL.D. Pp. vii + I4I.

THOMAS JEFFERSON. His Permanent Influence on American Institutions. By John Sharp Williams, U. S. Senator from Mississippi. Pp. ix + 330 .

THE MEChanics OF laW MAKING. By Courtenay Ilbert, G. C. B., Clerk of the House of Commons. Pp. viii +209.

LAW AND ITS ADMINISTRATION. By HARLAN F. STONE, LL.D., Dean of the School of Law, Columbia University. Pp. vii +232.

AMERICAN CITY PROGRESS AND THE LAW. By HOWARD LEE MCBAIN, Ph.D., Eaton Professor of Municipal Science and Administration, Co. lumbia University. Pp. viii +269.

Uniformly bound, $12 \mathrm{mo}$, cloth. Each, $\$ 2.00$ net.

THE LAW AND THE PRACTICE OF MUNICIPAL HOME RULE. By HowARD LEE McBAIN, Eaton Professor of Municipal Science and Administration in Columbia University. 8vo, cloth, pp. xviii +724 . Price, $\$ 5.00$ net.

STUDIES IN SOUTHERN HISTORY AND POLITICS. Inscribed to William Archibald Dunning, Lieber Professor of History and Political Philosophy in Columbia University, by his former pupils, the authors. A collection of fifteen essays. 8vo, cloth, pp. viii +294 . \$3.00 net.

THE ENGLISH.SPEAKING BROTHERHOOD AND THE LEAGUE OF NATIONS. By Sir Charles Walston (Waldostein), M. A., Litt. D., formerly Professor in the University of Cambridge. I 2mo, boards, pp. xxiii-224, $\$ 1.60$ net.

COLUMBIA UNIVERSITY PRESS

LEMCKE \& BUEOHNER, Agents

30-32 East Twentieth Street, New York City 


\section{LONGMANS, GREEN \& CO.}

THE VILLAGE LABOURER, 1760-1832: A Study in the Government of Eng. land before the Reform Bill. By J. L. and.Barbara Hammond. 8vo. \$2.25 not.

"There is not a chapter in Mr. and Mrs. Hammond's book which fails to throw new light on enclosures or on the administration of the poor laws and the game laws, and on the economic and social conditions of the period. . . . A few other studies of governing class rule before 1867 as searchingly analytical as $\mathrm{Mr}$. and Mrs. Hammond's book will do much to weaken this tradition and to make imperative much recasting of English History from I688." -

-Am. Political Science Review.

THE TOWN LABOURER, 1760-1832: The New Civilization. By J L. HamInond and Barbara Hammond, Authors of "The Village Labourer, I760-1832: A Study in the Government of England before the Reform Bill." 8vo. $\$ 2.25$ net.:

This volume is the first part of a study of the Industrial Revolution. It will be completed by another volume giving in detail the history of the workpeople in various industries, with a full account of the Luddite rising and of the disturbances connected with the adventures of the agent provocateur Oliver.

" Never has the story been told with such masterly precision, or with such illuminating reference to the original sources of the time, as in this book .... The perspective and proportion are so perfect that the life of a whole era, analyzed searchingly and profoundly, passes before your eyes as you read." -The Dial.

"A brilliant and important achievement. 'The Town Labourer' will rank as an indispensable source of revelation and of inspiration." -The Nation (London).

BLACK AND WHITE IN THE SOUTHERN STATES : A Study of the Race Problem in the United States from a South African Point of View. By Maurice S. Evans. 8vo. \$3.00 net.

"This is a sequel to the author's earlier volume. BLACK AND WHITE IN South EAst AsRicA. It is a product of the same searching insight and the same candid observation."-American Journal of Sociology.

BLACK AND WHITE IN SOUTH EAST AFRICA: A Study in Sociology. By Maurice S. Evans. 8vo. \$3.00 net.

"An exceedingly lucid statement of the arduous and intricate problem which lies before the people of South Africa in dealing with the native races." -The Nation.

Second Edition, brought up to the Spring of 1919.

THE CONTROL OF THE DRINK TRADE IN BRITAIN. A Contribution to National Efficiency during the Great War, 1915-1918. By Henry Carter. With Illustrations, Charts, and Diagrams, and a new Preface by Lord D'Abernon 8vo. \$r.75 net.

His Grace the Archbishop of Canterbury says :

"The whole position concerning intemperance has been fundamentally altered by the war. I would very earnestly and seriously ask any who remain unconvinced, either as to the neeessity or the practicability of such changes, to read one book-sane, cool, lucid, and absolutely well-informed- The Control of the Drink Trade." ",

\section{Fourth Avenue and 30th Street, NEW YORK}




\section{LONGMANS, GREEN \& CO.}

THE ADMINISTRATION OF INDUSTRIAL ENTERPRISES. With Special Reference to Factory Practice. By EDWARD D. Jones, Ph.D., Professor of Commerce and Industry, University of Michigan. With Illustrations and Bibliographies. Large I 2mo. \$2.35 net. (Fifth Impression).

"To the head of any industrial organization, and especially to the executives of those which have not long been created and are still faced with many of the problems discussed in the volume, it should be particularly useful "-. Wall Street Fournal.

THE WORKS MANAGER TO-DAY: An Address Prepared for a Series of Private Gatherings of Works Managers. By SIDNEY WEBB, Professor of Public Administration in the University of London (School of Economic and Political Science). Crown 8vo. \$I.35 net

An examination, in easy lecture form, of the problems of management of any considerable industrial enterprise, especially in relation to the organization of labor, methods of remuneration, "Scientific Management" and "Welfare Work," piecework and premium bonus systems, restriction of output and increase of production, the maintenance of discipline, etc.

THE ECONOMIC HISTORY OF THE UNITED STATES. By ERnest Ludlow Bogart, Ph.D., Associate Professor of Economics in the University of Illinois. With 26 Maps and 95 Illustrations. Crown 8vo, \$2.00.

READINGS IN THE ECONOMIC HISTORY OF THE UNITED STAtes. By E. L. Bogart, Ph.D., and C. M. Thompson, Ph.D., of the University of Illinois. 8vo. \$3.20.

A source book which collects in one volume contemporary material illustrating the most important economic developments in the country's history. The material is arranged as follows : Eight chapters deal with the United States before 1808 ; nine with the period of 1808-1860; and six with the period since 1860 .

RAILROADS. In two volumes. By William Z. Ripley, Ph.D. Nathaniel Ropes Professor of Economics in Harvard University, author of "Railway Problems," etc.

Vol. I. RATES AND REGULATION, with \&I maps and diagrams. 8vo. \$4.00 net.

Vol. II. FINANCE AND ORGANIZATION, with 29 maps and diagrams. 8vo. \$4.00 net.

PRINCIPLES OF ECONOMICS : with Special Reference to American Conditions. By EDwin R. A. Seligman, LL. D. McVickar Professor of Political Economy in Columbia University. Eighth Edition, Revised (1919). \$3.00 net.

AN ESSAY ON MEDIEVAL ECONOMIC TEACHING. By George O'Brien, Litt.D., author of “The Economic History of Ireland in the Seventeenth Century," "The Economic History of Ireland in the Eighteenth Century, etc." \$4 75 net.

It is the aim of this essay to examine and present in as concise a form as possible the principles and rules which guided and regulated men in their economic and social relations during the period known as the Middle Ages.

\section{Fourth Avenue and 30th Street, NEW YORK}




\section{P.S. KING \& SON, Ltd.}

\section{INSURANCE AGAINST UNEMPLOYMENT}

With special reference to conditions in Great Britain and the United States of America. By JosepH L. CoHen, B.A. Cantab.; M.A., and Gilder Fellow in Economics, Columbia University. 18s. Postage 1s.

A comprehensive study of the Problem of the Prevention of Unemployment in the United States, Great Britain, and in Europe.

\section{PROHIBITION IN AMERICA, AND ITS RELATION TO THE PROB- LEM OF PUBLIC CONTROL OF PERSONAL CONDUCT}

By Sir Arthor Newsholme, K.C.B., M.D., Author of "Public Health and Insurance," \&c. ; Lecturer on Public Health Administration in Johns Hopkins

University; late Principal Medical Officer to the Local Government Board of

England. Price 2s. 6d. Postage 2d.

Methodist Times: "We suggest that all who aspire to pass an opinion on the Prohibition question should read this book. . contains a History of the Prohibition Movement and a careful analysis of the motives leading to National Prohibition. . . There is also as an Appendix, a Summary of the National Prohibition Act."

\section{PRINCIPLES OF COMPARATIVE ECONOMICS}

By Radhakamal Mukerjee, M.A., Ph.D., Professor of Economics and Sociology, Lucknow University; Premehand Roychand Scholar; Sometime Professor of Economics, Krishnath College, Berhampore; Special Lecturer in Indian Economics, University of the Punjab, 1917, late Lecturer in Economics, PostGraduate Department, Calcutta University; Author of "The Foundations of Indian Economics." Vol. I ready. Price 15s. Postage 2s. Vol. II will be issued early in 1922. Price 18s. With a Preface in French by RAPHAELGeorges Levy, Senateur, Membre de l'Institut de France, etc.; with English Translation.

In the first volume the author examines the principles of economics; in the second he describes the situation in India.

Several chapters are devoted to the social dynamic, to what has been called the spiral of production, to marginal limitations, to evolution, to co-operative productivity studied as a new factor in economics, to the laws of consumption.

\section{PRICES AND WAGES}

An Investigation of the Dynamic Forces in Social Economics. By Percy Waldis and AlBert Wallis. Royal 8vo. $480 \mathrm{pp.}$ With numerous Charts and Diagrams. 25s. Postage 1s.

Co-partnership: "The importance of this work cannot be over estimated . . the book is of the utmost value to students of economics and sociology . . . an excellent course for study circles during the coming winter session."

\section{WEALTH AND ITS TAXABLE CAPACITY}

By Sir Josian Stamp, K. B.E., D.Sc., Guy Medallist of the Royal Statistical Society, and late of the Inland Revenue Department. Being the Newmarch Lectures of 1920-21. Price 10s. 6d. Postage 9d.

In the House of Commons during the Debates on Taxation and the Budget, these Lectures were referred to by several Members, and the Chancellor of the Exchequer stated that he understood they would be published. Sir Josiah Stamp has now revised them and they will be issued shortly.

\section{MONETARY POLICY}

Being the Report of a Sub-Committee appointed by the Research Committee of the British Association for the Advancement of Science on Currency and the Gold Standard. 2s. 6d. Postage 2d.

\section{Orchard House, 2-4 Great Smith Street Westminster, England}




\section{Studies in History, Economics and Public Law}

\section{edited by \\ Faculty of Political Science of Columbia University}

VOLUME I, 1891-92. 2nd Ed., 1897. 396 pp. Price, cloth, $\$ 3.50$.

1. The Divorce Problem. A Study in Statistics.

1. The WAltre F. Willcox, Ph.D. Price, 75 cents.

2. The History of Tariff Administration in the United States, from Colonial Times to the McKinley Administrative Bill.

By John Dean Goss, Ph.D. Price, $\$ 1.00$.

3. History of Municipal Land Ownership on Manhattan Island.

By Grorga Ashton Black, Ph.D. Price, \$1.00.

4. Financial History of Massachusetts.

By Charles H, J. Dougras, Ph.D. Price, \$1.00.

VOLUMS II, 1892-93. (See note on last page.)

1. [5] The Economics of the Russian Village.

By IsAac A. Hourwich, Ph.D. (Out of print).

2. [6] Bankruptcy. A study in Comparative Legislation.

By SAMUeL W. Dunscomb, Jr., Ph.D. (Not sold separately.)

3. [7] Special Assessments; A Study in Municipal Finance.

By Victor Rosewater, Ph.D. Second Edition, 1898. Price, \$r.oo.

VOLUME III, 1893. $465 \mathrm{pp}$. (See note on last page.)

1. [8] *History of Elections in American Colonies.

1. 2. [9] The Commercial Pollcy of England toward the American Colonies. By GRORGB L. BEBR, A. M. (Out of print.)

VOLUME IV, 1893-94. $438 \mathrm{pp}$. (See note on last page.)

1. [10] Financial History of Virginia.

(Dy William $Z$. Ripley, Ph.D. (Not sold separately) 2. [11 $]^{*}$ The Inheritance Tax. ByMax WeST,Ph.D. Second Edition.19o8. Price.\$200. 8. [12] Histo"v of Taxation in Vermont. By Frederick A. Wood, Ph. D. (Out of print)

VOLUME V, 1895-96. 498 pp. Price, cloth, $\$ 3.50$.

1. [13] Double Taxation in the United States.

2. [14] The Separation of Governmental Powers.

8. [15] Municipal Government in Michigan and Ohio.

By Wiliam Bondy, Ll. B., Ph.D. Price, \$r.00. By Delos F. Wricox. Ph.D. Price, $\$ x . \infty$.

VOLUME VI, 1896. 601 pp. Price, cloth, $\$ 4.50$; Paper covers, $\$ 4.00$. [16] History of Proprietary Government in Pennsylvania.

By William Robert Shrpherd, Ph.D.

VOLUME VII, 1896. 512 pp. Price, cloth, $\$ 3.50$.

1. [17] History of the Transition from Provincial to Commonwealth Government in Massachusetts.

2. [18]*Specalation on the Stockand Produce Exchanges of the United States By HeNry Crosby Embry, Ph.D. Price, \$1.50.

\section{VOLUME VIII, 1896-98. 551 pp. Price, cloth, $\$ 4.00$.}

1. [19] The Struggle between President Johnson and Congress over Reconstruction. 2. [20] Recent Centralizing Tendencies in State Educational Administration.

3. [21] The Abolition of Privateoring and the Declaration of Paris. 1. [22] Public Administration in Massachusetts. The Relation of Centrai to Local Activity.

VOLUME IX, 1897-98. "617 pp. Price, cloth, $\$ 4.00$.

1. [23] *English Local Government of To-day. A Study of the Relations of Central and Local Government. 2. [24] German Wage Theories. A History of their Development.

B. [25] The Centralization of Administration By JAMrS W. CROOK, Ph.D. Price, \$r.00. By John ARChibald Falrie, Ph.D. Price, $\$$ r.o. 
VOLUME X, 1898-99. 409 pp. Price, cloth, \$3.50.

1. [26] Sympathetio Strikes and Sympathetic Lockouts.

By Fred S. Halx, Ph.D. Price, \$1.0 2. [27] *Rhode Island and the Formation of ihe Union.

By Frank Greme Bates, Ph.D. Price, 8t.50.

3. [28]. Centralized Administration of Liquor Laws in the American Com. monwealths.

By Clement Moore Lacey Sires, Ph.D. Price, $\$ 1.00$.

VOLOME XI, 1899. 495 pp. Price, cloth, 4.00; paper covers, $\$ 3.50$.

9] The Growth of Cities.

By Adna Frrrin Webrr Ph.D.

VOLUME XII, 1899-1900. $586 \mathrm{pp.}$ Price, cloth, $\$ 4.00$.

[30] History and Functions of Central Labor Unions.

*. [31.] Colonial Immigration Laws.

By William Maxwell Burke, Ph.D. Price, \$x.00.

8. [32] History of Military Pension Legislation in the United States.

By William Hrnky Glasson, Ph.D. Price, \$1.00. 4. [33] History of the Theory of Sovereignty since Roussean.

By Charles E. Mrrriam, Jr., Ph.D. Price, \$r.50.

VOLUME XIII, 1901. 570 pp. Price, cloth, $\$ 4.00$.

1. [34] 'Whe Legal Property Relations of Married Parties.

By IsIDOR LozB, Ph.D. Price, \$1.5a.

2. [35] Polltical Nativism in New York 8tate.

3.

3. [38] The Reconstruction of Georgla. By Edwin C. Woolley, Ph.D. Price, $\$ x . \infty$.

VOLUME XIV, 1901-1902. 576 pp. Price, cloth, \$4.00.

1. [37] Loyalism in New York during the American Revolution.

.

2. [38] The Economic Theory of Risk and Insurance.

By Allan H. Willett, Ph.D. Price, \$r.5o.

3. [39] The Eastern Question: A Study in Diplomacy.

By Stephen P. H. Duggan. Ph.D. Price, \$r.oo.

VOLUME XV, 1902. 427 pp. Price, cloth, \$3.50; Paper covers, $\$ 3.00$.

[40] Crime in Its Relation to Social Progress. By Arthur Clegrland Hall, Ph.D.

VOLUME XVI, 1902-1903. 547 pp. Price, cloth, $\$ 4.00$.

1. [41] The Past and Present of Commerce in Japan.

2. [42] The Employment of Women in the Clothing Trade.

8. [48] The Centralization of Administration in Ohio.

By Mabri HuRd Willet, Ph.D. Price, \$r.50.

By Samuel P. Orth, Ph.D. Price, \$1.50.

VOLUME XVII, 1903.635 pp. Price, cloth, $\$ 4.00$.

1. [44] *Centralizing Tendencies in the Administration or Indiana.

By William A. Rawles, Ph.D. Price, \$2.5a

2. [45] Principles of Justice in Taxation. By Strphen F. Weston, Ph.D. Price, \$2.00.

VOLUME XVIII, 1903. 753 pp. Price, cloth, \$4.50.

1. [46] The Administration of Iowa. By Harold Martin Bowman, Ph.D. Price, \$1.5o.

2. [47] Turgot and the Six Edicts. By Robert P. Shepherd, Ph.D. Price, \$1.50.

3. [48] Hanover and Prassia, 1795-1803. By Guy Stanton Foed, Ph.D. Price, 82.00.

VOLUME XIX, 1903-1905. $588 \mathrm{pp}$. Price, cloth, $\$ 4.00$.

1. [49] Josiah Tucker, Economist. By Wartar Ernest Clark, Ph.D. Price, \$r.50.

2. [50] History and Criticism of the Labor Theory of Value In Knglish Polit-

8. lcal Fconomy. 8. [51] Trade Unions and the Law In Now York.

By Grorge Gorham Groat, Ph.D. Price, \$1.00.

VOLUME XX, 1904. 514 pp. Price, cloth. $\$ 3.50$.

1. [52] The Offce of the Justice of the Poace in England.

By Charles Austin Brard, Ph. D. Price, 81.50.

2. [53] A History of Military Government in Newly Acuuired Territory of the United states.

By David Y. Thomas, Ph. D. Price, \$2.00.

VOLUME XXI, 1904. 746 pp. Price, cloth, $\$ 4.50$.

1. [54] *Treaties, their Making and Enforcement.

2. [55] The Sociology of a New York City Block.

By Thomas Jrsse Jonks, Ph.D. Price, \$1.00.

3. [56] Pre-Malthusian Doctrines of Popuiation.

- By Charles E. Stangeland, Ph.D. Price, 82.50. 
VOLUME XXII, 1905. 520 pp. Price, cloth, $\$ 3.50$; paper covers, $\$ 3.00$. (57) The Historical Development of the Poor Law of Connecticut.

VOLUME XXIII, 1905. $594 \mathrm{pp}$. Price, cloth, $\$ 4.00$.

1. [58] The Fconomics of Land Tenure in Georgla.

By ENoch Marvin Banks, Ph.D. Price, \$r.oo.

2. [59] Mistake in Contract. A Study in Comparative. Iurisprudence.

3. [60] Combination in the Mining Industr By EDwin C. MCKEAG, Ph.D. Price, \$r.o.

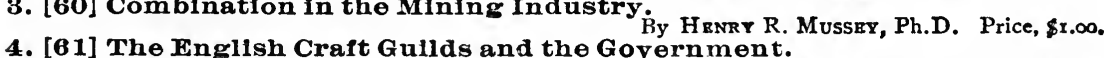

By Strlia Kramzr. Ph.D. Price, \$1.00.

VOLUME XXIV, 1905. $521 \mathrm{pp.}$ Price, cloth, $\$ 4.00$.

1. [62] The Place of Magic in the Intellectual History of Europe. 2. [63] The Ecclesiastical Edicts of the Theodoslan Code.

By WILLIAM K. Boyd, Ph.D. Price, \$r.oo.

3. [64] *The International Position of Japan as a Great Power.

By SErji G. Hishrida, Ph.D. Price, $\$ 2.00$

VOLUME XXV, 1906-07. 600 pp. (Sold only in Sets.)

1. [65] *Municipal Control of Public Utilities. 2. [66] The Budget in the American Commonwealths. Ph.D. (Not sold separately.)

3. [67] The Finances of Cleveland. By CHy EUGENE E. AgGer, Ph.D. Price, \$r.5o.

VOLUME XXV1, 1977. 559 pp. Price, cloth, \$4.00.

1. [68] Trade and Currenoy in Early Oregon.

2. [69] Luther's Table Talk.

By James H. Grlbert, Ph.D. Price, \$x.oo.

3. [70] The Tobacco Industry in the United States.

1. [71] Social Democracy and Population.

By Mzyzr Jacobstrin, Ph.D. Price, \$1. 50.

By Alvan A. Trnney, Ph.D. Price, 75 cents.

VOLUME XXVII, 1907. 578 pp. Price, cloth, $\$ 4.00$.

1. [72] The Economic Pollcy of Robert Walpole.

2. [73] The United States Steel Corporation.

By Norris A. Brisco, Ph.D. Price, $\$ x .50$.

By Abraham Berglund, Ph.D. Price, $\$ 150$.

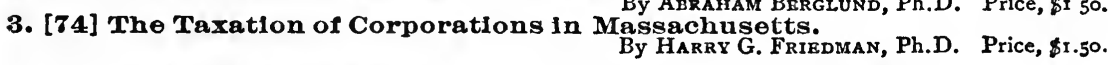

VOLUME XXVIII, 1907. 564.pp. Price, cloth, $\$ 4.00$.

1. [75] Dewitt Clinton and the Origin of the Spolls System in New York.

1. [76] De

2. [76] The Development of the Legislature of Colonial Virginia.

3. [77] The Distribution of Ownership.

By ELMER I. MIILLER, Ph.D. Price, \$r.5o.

By Joseph Harding Underwood, Ph.D. Price, \$r.5o.

VOLUME XXIX, 1908. $703 \mathrm{pp.}$ Price, cloth, $\$ 4.50$.

1. [78] Early New England Towns. By Anne Bush MacLrar, Ph.D. Price, \$r.50. 2. [79] Now Hampshire as a Royal Province.

By William H. Fry, Ph.D. Price, \$3.00.

VOLUME XXX, 1908. 712 pp. Price, cloth, \$4.50; Paper covers, $\$ 4.00$.

[80] The Province of New Jersey, 1664-1738.

By Edwin P. TANner, Ph.D.

VOLUME XXXI, 1908. $575 \mathrm{pp}$. Price, cloth, $\$ 4.00$.

1. [81] Private Freight Cars and American Railroads.

182]

3. [83] Consanguineous Marriages in the American Population.

By GEORGB B. Lours ARner, Ph.D. Price, 75 cents.

4. [84] Adolphe Quetelet as Statistician. By Frank H. Hankins, Ph.D. Price, \$1.25.

VOLUMF XXXII, 1908. 705 pp. Price, cloth, 4.50; paper covers, \$4.00.

85] The Enforcement of the Statutes of Laborers.

VOLUME XXXIII, 1908-1909. 635 pp. Price, cloth, $\$ 4.50$.

1. [86] Factory Legislation in Maine.

. [87] *Psjchological Interpretations of Society.

3. [88] *An Introduction to the Sources relating to the Germanic Invasions.

By Chriton J. H. Hayes, Ph.D. Price, $\$ 1.50$. 
VOLUME XXXIV, 1909. 628 pp. Price, cloth, \$4.50.

x. [89] Transportation and Industrial Development in the Middle West.

6. [90] Social Reform and the Reformation. By William F. Gephart, Ph.D. Price, \$2.00.

8. [91] Responsibility for Crime. By Philip A. Parsons, Ph.D. Price, \$r.50.

VOLUME XXXV, 1909. 568 pp. Price, cloth, $\$ 4.50$.

1. [82] The Conflict over the Jndiclal Powers In the United States to 1870.

By CHARLES GROYB HAINES, Ph.D. Price, \$r.50. 8. [93] A Study of the Popnlation of Manhattanville.

8. [84] * Divorce: A Study in social Causation.

By Howard Brown Woolston, Ph.D. Price, \$r.25. By James P. Lichtenberger, Ph.D. Price, $\$ \mathbf{r} .50$.

VOIUME XXXVI, 1910. $542 \mathrm{pp}$. Price, cloth, $\$ 4.00$.

1. [95] * Reconstruction in Texas. By Charles William Ramsdeli. Ph.D. Price, \$2.50. 2. [96] * The Transition in Virginia from Colony to Commonwealth.

By Charles RAMSDell. Lingley, Ph.D. Price, \$1.50.

VOLUME XXXVII, 1910. 606 pp. Price, cloth, $\$ 4.50$.

1. [97] Standards of Reasonableness in Local Freight Discriminations.

2. [98] Legal Development in Colonial Massachusetts.

By John Maurice CLARK, Ph.D. Price, \$r.25.

8. [99] * Social and Mental Traits of the Negro.

By Charles J. Hilkex, Ph.D. Price, \$r.25. By Howard W. Odum, Ph.D. Priee, \$a.oo.

VOLUME XXXVIII, 1910. 463 pp. Price, cloth, $\$ 3.50$.

1. [100] The Public Domain and Democraç. 8. [101] Organismic Theories of the State. By Francis W. Cokre, Ph.D. Price, \$r.go.

VOLUME XXXIX, 1910-1911. 651 pp. Price, cloth, $\$ 4.50$.

1. [102] The Making of the Balkan States.

2. [103] Political History of New York Sy Willam SMrth MurRay, Ph.D. Price, \$r.50. War.

VOLUME XL, 1911. 633 pp. Price, cloth, \$4.50.

1. [104] A Survey of Constitutional Development in China.

8. [105] Ohto Politios during the Civil War Py HAwKLING L. Y BN, Ph.D. Price, \$r.00. 8. [105] Ohio Polftios during the Civil War Period.

8. [106] The Territortal Basis Grorgs H. PORTkR, Ph.D. Price, \$r.75 By ALPRRD ZANTZiNGRR RBED, Ph.D. Price, \$1.75.

VOLUME XLI, 1911 . 514 pp. Price, cloth, $\$ 3.50$; paper covers, $\$ 3.00$. [107] New Jersey as a Royal Province.

By Edgar Jacob Fishirr, Ph. D.

VOLUME XLII, 1911. 400 pp. Price, cloth, \$3.00; paper covers, \$2.50.

[108] Attitude of American Courts in Labor Cases.

By Grorga Gorham Groat, Ph.D.

VOLUME XIIII, 1911. $633 \mathrm{pp.}$ Price, cloth, $\$ 4.50$.

1. [109] *Industrial Causes of Congestion of Popnlation in New York City.

8. [110] Education and the Mores. By EDWARd EwING PRATT, Ph.D. Price, \$2.00, 8. [111] The British Consuls in the Confederacy.

By Milledge L. Bonham, Jr., Ph.D. Price, \$2.00.

VOLUMES XLIV and XLV, 1911. $745 \mathrm{pp}$.

Price for the two volumes, cloth, $\$ 6.00$; paper covers, $\$ 5.00$.

[112 and 113] The Economic Principles of Confucius and his School. By Chen Huan-Chang, Ph.D.

VOLUME XLVI, 1911-1912. 623 pp. Price, cloth, $\$ 4.50$.

1. [114] The Ricardian Socialists.

By Esther Lowenthad, Ph.D. Price. $\$ 1,00$ 8. [115] Ibrahim Pasha, Grand Vizier of Suleiman, the Magnificent. *. [116] *Syndicalism in France. 
VOLUME XLVII, 1912. 544 pp. Price, cloth, $\$ 4.00$.

1. [118] The Politics of Michigan, 1865-1878,

3. [1 19] *The United States Beet Sugar Industry and the Tariff.

BY ROY G. BLAkEY, Ph.D. Price, \$2.00.

VOIUME XIVIII, 1912. $493 \mathrm{pp}$. Price, cloth, $\$ 4.00$.

1. [120] Isidor of Seville.

By Ernest Brehnut, Ph. D. Price, \$2.00.

3. [121] Progress and Uniformity in Child-Labor Legislation.

By William Fielding OgruRn, Ph.D. Price, \$1.75.

VOLUME XLIX, 1912. 592 pp. Price, cloth, \$4.50.

1. [122] British Radicalism 1791-1797.

By Walter Philps Hall. Price, \$2.00.

2. [123] A Comparative Study of the Law of Corporations.

8. [124] *The Negro at Work in New York City.

By Arthur K. Kuns, Ph.D. Price, \$1.50.

By Grorger E. Haynes, Ph.D. Price, \$1.25.

VOLUME L, 1911. $481 \mathrm{pp}$. Price, cloth, $\$ 4.00$.

1. [125] *The Spirit of Chinese Philanthropy. Bx YaI YuE Tsu, Ph.D. Price, \$r.co. 2. [126] *The Alien in China.

VOLUME II, 1912. 4to. Atlas. Price: cloth, \$1.50; paper covers, \$1.00. 1. [127] The Sale of Liquor in the Sonth.

VOIJME LII, 1912. $489 \mathrm{pp}$. Price, cloth, $\$ 4.00$.

1. [128] *Provincial and Local Taxation in Canada.

x. [129] *The Distribution of Income.

8. [130]*The Finances of Vermont.

By Solomon Vingerre, Ph.D. Price, 81.50 .

By Frank Hatcr Streightoff, Ph.D. Price, $\$ 1.50$.

By FREDERICK A. WOOD, Ph.D. Price, $\$ 1.00$.

VOLUME IIII, 1913. 789 pp. Price, cloth, \$4.50; paper, \$4.00.

[131] The Civil Warand Reconstruction in Florida. By W. W. Davis, Ph.D.

VOLUME LIV, 1913. 604 pp. Price, cloth, $\$ 4.50$.

1. [132] * Privileges and Immunities of Citizens of the United States.

1.

2. [133] The Supreme Court and Unconstitutional Legisiation.

By BLAinz Frem MOORz, Ph.D. Price, \$1.00.

8. [134] *Indian Slavery in Colonial Times within the Present Iimits of the United States.

By Almon Whater Lauber, Ph. D. Price, $\$ 3.00$.

VOLUME LV, 1913. 665 pp. Price, cloth, $\$ 4.50$.

1. [135] *A Political History of the State of New York.

8. [186]

8. [136] *The Early Persecutions of the Christians.

By Leon H. Cameirld, Ph.D. Price, \$r.50.

VOLUME LVI, 1913. 406 pp. Price, cloth, \$3.50.

1. [137] Speculation on the New York Stock Exchange, 1904-1907.

By Algernon Ashberner Osborne. Price, \$1.50. 2. [138] The Policy of the United States towards Industrial Monopoly. By Oswald Whitman Knauth, Ph.D. Price, $2 . \infty$.

VOLUME LVII, 1914. 670 pp. Price, cloth, \$4.50.

1. [139] *The Civil Service of Great Britain.

f. [140] The Financlal Histcry of New York State.

By Robert Moses, Ph.D. Price, \$2.00. By Don C. Sowrers. Price, 82.50 .

VOLUME IVIII, 1914. 684 pp. Price, cloth, $\$ 4.50$; paper, $\$ 4.00$.

[141] Reconstruotion in North Carolina.

VOLUME LIX, :914. 625 pp. Price, cloth, \$4.50.

3.. [142] The Development of Modern Turkey by means of its Press,

3.0 2. [143] The System of Taxation in China, 1614-1911.



Whan Chen, Ph. D. Price, $\$ 1.00$

By Samurl Joseph, Ph.D. Price, \$x.50. 
VOLUME LX. 1914. $516 \mathrm{pp.} \mathrm{Price,} \mathrm{cloth,} \$ 4.00$.

1. [146] *Constantine the Great and Christianity.

By Chistophri Bush Colzman, Ph. D. Price, \$2.00.

2. [147] The Establishment of Christianity and the Proseription of Pagauism.

By Maud Aline Hurtman, Ph.1). Price, 2.20 .

VOLUME IXI. $1914.496 \mathrm{pp.}$ Price, cloth, $\$ 4.00$.

1. [148] *The Railway Conductors: A Study in Organized Labor.

2. [149] *The Finances of the City of New York.

By EDwin CLyde Robins. Price, \$r.50. By YrN-Ch'U Ma, Ph.D Price, \$2.50.

VOLUME LXII. 1914. 414 pp. Price, cloth, $\$ 3.50$.

[150] The Journal of the Joint Committee of Fifteen on Reconstruction. 39 th Congress, $1865-1867$.

By Benjamin B. Kandrick, Ph. D. Price, $\$ 3.00$.

VOLUME LXIII. 1914. $561 \mathrm{pp.} \mathrm{Price,} \mathrm{cloth,} \$ 400$.

1. [151] Emile Durkheim's Contributions to Sociological Theory.

2. [152] The Nationalization of Railways in Japan.

3. [153] Population: A Study in Malthusianism.

By WARKEN S. ThOMPSON, Ph.D.

Price, $\$ 1.75$.

VOLUME LXIV. 1915. $646 \mathrm{pp}$. Price, cloth, $\$ 4.50$.

1. [154] *Reconstruction in Georgia. By C. Milden Thompson, Ph.D

2. [155] *The Review of Americau Colonial Legisiation by the Council.

By ELMER BRECHER KuSSELL, Ph. $\mathrm{D}$.

Price, 3.00. King in Price, \$1.75.

VOLUME LXV. 1915. 524 pp. Price, cloth, \$4.00.

1. [156] *The Sovereign Council of New France 2. [157] *Scientific Management (2nd. ed. 1918).

By Horace B. Drury, Ph.D. Price, \$2.00

VOLUME LXVI. 1915. $655 \mathrm{pp.} \mathrm{Price,} \mathrm{cloth,} \$ 4.50$.

1. [158] *The Recognition Policy of the United States.

2. [159] Rallway Probiems in China.

3. $[160]$ *The Boxer Rebelition.

By Julius Goвber, JR., Ph.D. Ву Снгн $\mathrm{Hsu}, \mathrm{Ph} . \mathrm{D}$

By Paur. H. Clements, Ph.D.

Price, \$2.00. Price, \$1.50. Price, \$2.00.

VOLOME IXVII. 1916. $538 \mathrm{pp}$. Price, cloth, $\$ 4.00$.

1. [16 1] *Russian Sociology.

By Julius F. Hzcker, Ph.D. Price, \$2.50. 2. [162] State Regulation of Rallroads in the South.

By Maxwell Frequson, A. M., LL.B. Price, \$1.75.

VOLUME LXVIII. 1916.518 pp. Price, cloth, $\$ 4.50$.

[168] The Origins of the Islamic State. By Philip K. Hitri, Ph.D. Price, \$4.0.

VOLUME LXIX. 1916. 489 pp. Price, cloth, $\$ 4.00$.

1. [164] Railway Monopoly and Rate Regulation. 2. [165] The Butter Industry in the United States.

By Edward Wiest, $\mathrm{Ph}$ D. Price, \$2.00.

VOLOME LXX. 1916. $540 \mathrm{pp.} \mathrm{Price,} \mathrm{cloth,} \$ 4.50$.

[166] Mohammedan Theories of Finance ${ }_{B y}$ Nicolas P. Aghides, Ph. D. Price, $\$ 4.00$.

VOLUME LXXI. 1916. $476 \mathrm{pp.} \mathrm{Price,} \mathrm{cloth,} \$ 4.00$.

1. [167] The Commerce of Louisiana during the French Regime, 1699-1763. By N. M. Miller SURREY, Ph.D. Price, $\$ 3.50$.

VOLUME LXXII. 1916. $542 \mathrm{pp.}$ Price, cloth, $\$ 4.50$.

1. '168] American Men of Letters: Their Natare and Nurture.

2. [169] The Tarff Problem in China.

3. 170$\}$ The Marketing of Perishable Food Products.

By Edwin LravitT Clarke, Ph.D. Price, \$1.50. By Chin Cuu, Ph.D. Price, \$r.50.

By A. B. Adams, Ph.D. Price, $\$ \mathbf{x} .50$. 


$$
\text { . }
$$





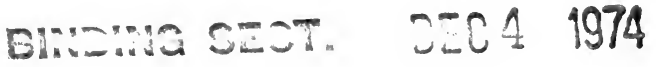

\section{PLEASE DO NOT REMOVE \\ CARDS OR SLIPS FROM THIS POCKET}

\section{UNIVERSITY OF TORONTO LIBRARY}

JX

1425

138
Lawson, Leonard Axel

The relation of British policy 
chis 